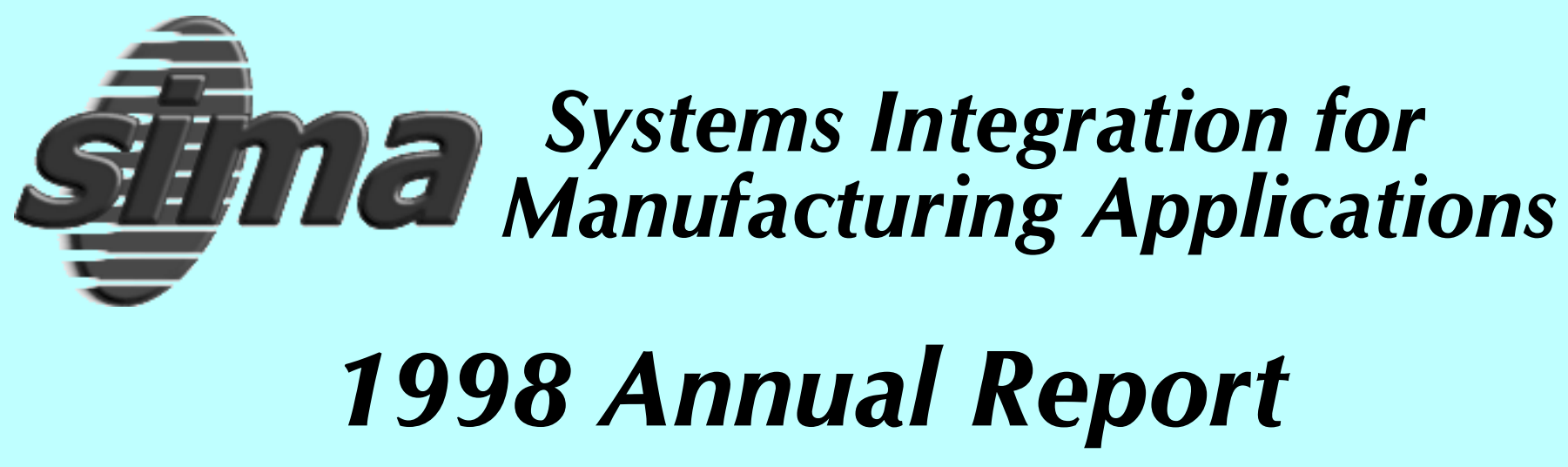

James E. Fowler 


\section{Systems Integration for Manufacturing Applications 1998 Annual Report}

James E. Fowler

Manufacturing Systems Integration Division Manufacturing Engineering Laboratory National Institute of Standards and Technology

April 1999

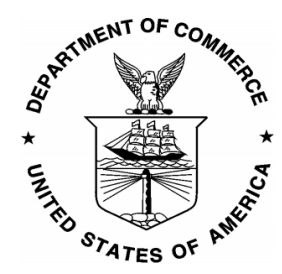

U.S. DEPARTMENT OF COMMERCE

William M. Daley,

* Secretary of Commerce

Technology Administration

Gary R. Bachula,

Acting Under Secretary for Technology

National Institute of Standards and Technolog!

Raymond Kammer,

Director 


\section{Program Office Staff}

The SIMA Program Office is responsible for managing and compiling information for all projects supported by the SIMA Program. The SIMA Program Office staff are:

- James Fowler (Program Manager) jefowler@nist.gov

- Mark Carlisle (Administrative Specialist) carlisle @cme.nist.gov

- Clarence Johnson (Program Analyst) ceejay@cme.nist.gov

\section{Disclaimer}

No approval or endorsement of any commercial product by the National Institute of Standards and Technology is intended or implied. Certain commercial equipment, instruments, or materials are identified in this report in order to facilitate understanding. Such identification does not imply recommendation or endorsement by the National Institute of Standards and Technology, nor does it imply that the materials or equipment identified are necessarily the best available for the purpose.

This publication was prepared by United States Government employees as part of their official duties and is, therefore, a work of the U.S. Government and not subject to copyright. 


\section{Table of Contents}

Introduction ........................................................................................................................................

SIMA Overview ...........................................................................................................................1

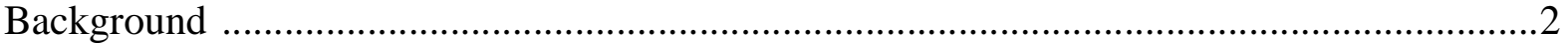

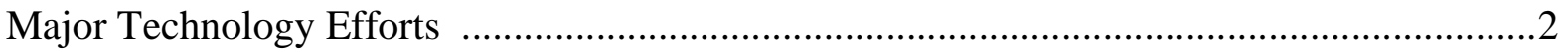

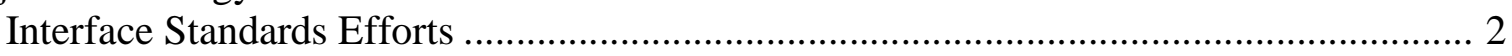

Information Access Efforts ............................................................................. 11

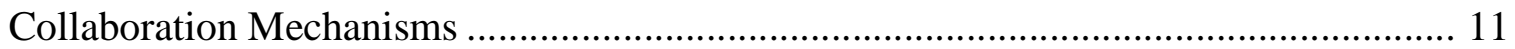

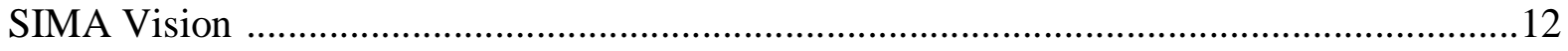

Project Accomplishments ...................................................................................................................13

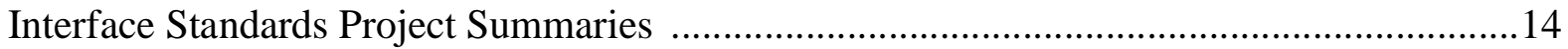

IS1: Application Protocol Development Environment (APDE) ……………………….....14

IS2: Design - Process Planning Integration (DPPI) …………………………………....16

IS3: Electronic Commerce for the Electronics Industry (ECEI) …………………….........17

IS4: Enterprise Resource Planning Interfaces (ERP-I) ...................................................19

IS5: Information Exchange Protocols for Design …………........................................2

IS6: Internet Commerce for Manufacturing ……………...........................................22

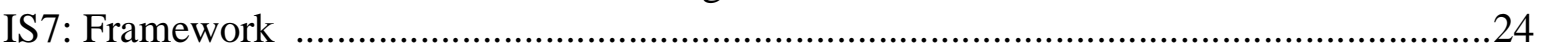

IS8: Operator Interfaces for Virtual and Distributed Manufacturing .................................26

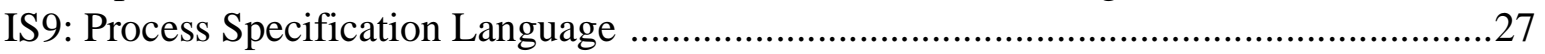

IS10: Production and Product Data Management Applications ........................................29

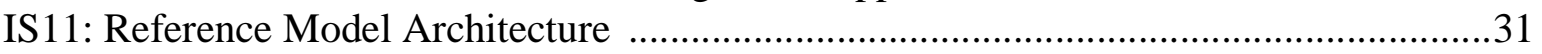

IS12: STEP Conformance and Interoperability Testing …………....................................33

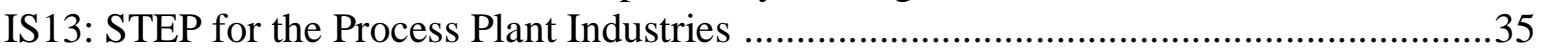

IS14: Virtual Environments and Visualization for Manufacturing ....................................36

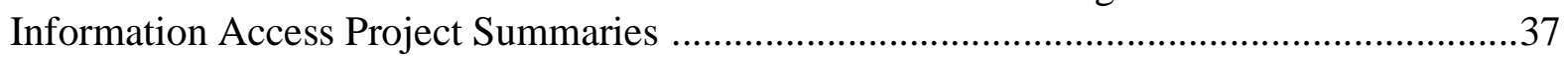

IA1: Analysis Tools for Assessment and Optimization of Process and Product Design ....37 IA2: Web-based Testing Service for Coordinate Measuring Machine (CMM) Software ...39

Standard Reference Data Delivery and Use Projects ..........................................................40

IA3: Computerized Access to Full Structural Crystallographic Data ……………….........40

IA4: Green's Function Library for Advanced Materials Applications with Web Access 41

IA5: Integration of NIST Standard Reference Data into Information Networks ...............41

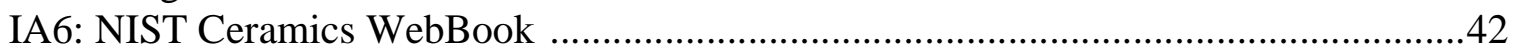

IA7: Online Access to NIST Chemical Reference Data ................................................42

IA8: Standards for Exchange of Instrument Data and NIST Chemical Reference Data ..43

IA9: Web-Based Bioinformatics Databases ...............................................................43

Collaboration Mechanisms Project Summaries ..................................................................4

CM1: NIST Manufacturing Collaboratory …………………………………………….....4

CM2: Virtual National Advanced Manufacturing Testbed (VNAMT) .................................46

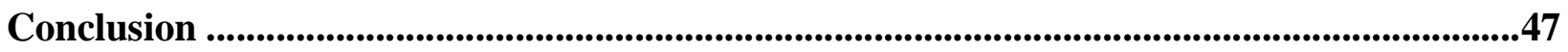

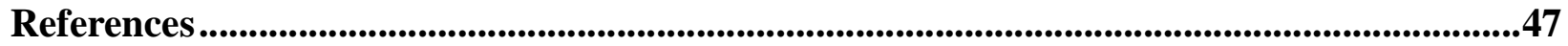

Appendix A: Program Organization ..........................................................................................................49

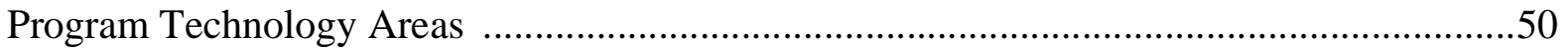


Participating NIST Organizational Units .............................................................50

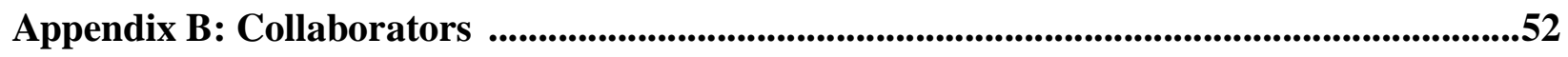

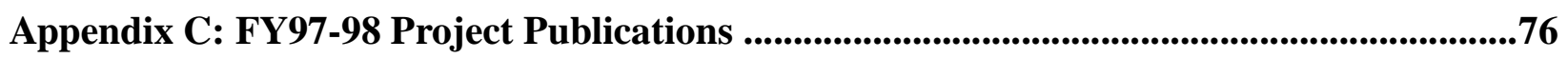

Appendix D: Program Products Newly Available in FY97-98 .................................................84 


\section{Introduction}

The Systems Integration for Manufacturing Applications (SIMA) Program is an intramural effort being undertaken at the National Institute of Standards and Technology (NIST) to support the application of information technologies to the manufacturing domain. Initiated in 1994, the Program works with industry to develop technology solutions enabling integration of the systems used in the engineering and manufacturing of various kinds of products. The plans for the Program were originally described in [1] and were updated in 1997 [2]. Program activities and project accomplishments for previous years have been documented in [3] and [4]. The purpose of this document is to report on two fiscal years of the Program's technical activities: 1997 and 1998 (FY97-FY98). The intended audience for this document includes private sector organizations and federal agencies collaborating with NIST, other agencies participating in the federal Computing, Information, and Communications (CIC) ${ }^{1}$ effort, and the general public. This report is available via the SIMA web page (http://www.nist.gov/sima/) or by electronic mail request to the SIMA Program Office secretary (simasec@ nist.gov).

This report is comprised of three major sections: the SIMA Overview, the Project Accomplishments, and the Appendices. The SIMA Overview section provides a high-level description of the Program's goals, technical efforts, results, and progress. The Project Accomplishments section provides individual descriptions for each of the projects funded by SIMA in FY97 and FY98. Each project description includes a summary of the project's technical accomplishments along with a list of the project's collaborators. The Appendices to the report include a description of the organization of the Program (Appendix A), tables summarizing all collaborators enumerated in each of the project descriptions (Appendix B), a list of publications completed by the projects (Appendix C), and a list of products available from the projects (Appendix D).

\section{SIMA Overview}

NIST's SIMA Program is the agency's coordinating focus for its CIC activities addressing the information interface needs of the U.S. manufacturing community. Specifically, the SIMA Program performs the following activities:

- develop standards for information exchange and interface protocols addressing interoperability problems in manufacturing systems.

- provide online access to NIST-resident capabilities supporting manufacturing technologies.

- develop collaboration technologies enabling industry researchers, practitioners, and NIST staff to remotely work together.

These efforts will allow manufacturing industries to make use of computer networks - be they local or wide-area, public or private - as a mechanism for communicating information among manufacturing activities. In the context of the SIMA Program the phrase "manufacturing activities" is broader than simply operations on the shop floor; it also includes activities such as the research conducted to devise new products and processes, the design of products and processes, the engineering analysis of prospective solutions, the planning of manufacturing operations, the scheduling of production operations, the engineering of production capabilities, and the myriad of other information-intensive activities required in industry today. All such activities are conducted using manufacturing software systems and these systems require information interfaces in order to communicate with each other. Those information interfaces may be realized as specifications for application programming interfaces, for data exchange protocols, or even as human-computer interfaces. The primary focus of the SIMA Program is the development and testing of information

1. The federal government's initiative in High Performance Computing and Communications was subsumed by the overarching multi-agency Computing, Information, and Communications efforts in 1997. 


\section{SIMA Overview}

interfaces that provide scientists, engineers, and manufacturing personnel with the capability to share information among different activities, among different application software components within manufacturing enterprises, and throughout the entire supply chain.

\section{Background}

The U.S. government initiated the High Performance Computing and Communication (HPCC) Program in 1991 with the High Performance Computing Act (Public Law 102-194). The government's effort was intended to accelerate the development of future generations of high performance computers and networks and the use of these resources in the government and throughout the U.S. economy. The four original components ${ }^{2}$ of the HPCC Program were augmented in FY94 with a new component known as Information Infrastructure Technology and Applications (IITA) [5]. The IITA component supported research and development efforts that would enable integration of critical information systems and demonstrate feasible solutions to problems of national importance [6]. Twenty-first century manufacturing, i.e., advanced manufacturing processes and products, was one of the challenges to be addressed by IITA activities [7]. In recognition of the HPCC Program's continuing successes and broadening scope, the Program was renamed as Computing, Information, and Communications and the components of the Program were refocused into Program Component Areas (PCAs) [8]. These PCAs build on the foundations established in the previously identified component domains and continue to address the HPCC challenge problems. The PCAs are known as High End Computing and Computation, Large-Scale Networking, High Confidence Systems, Human-Centered Systems, and Human Resources, Education, and Training. The Human Centered Systems (HuCS) PCA, which evolved from the IITA component, performs research and development making the products of computing systems and communication networks more easily accessible and useable to a wide range of user communities. HuCS efforts focus on knowledge repositories, collaboratories, multi-modal system interactions, and virtual reality environments. Information interface issues are central to such research and development efforts, hence NIST's SIMA Program is part of the larger multi-agency HuCS PCA [9].

\section{Major Technology Efforts}

SIMA technology efforts stem from both the short- and long-term needs of U.S. manufacturers and their software suppliers. Industry needs evolve in response to technology and market realities, thereby resulting in corresponding changes in the SIMA Program's project portfolio over time. Twenty-five (25) projects comprised the SIMA Program in FY97 and FY98. These projects addressed a wide range of industry manufacturing domains: chemical products, electrical products, materials, mechanical products, and constructed facilities. In this section, the focus is on the technology areas addressed in the projects. As illustrated in Figure 1 the Program is organized into three technology areas: Interface Standards, Information Access, and Collaboration Mechanisms. Appendix A of this document provides organizational details of the Program. Each technology area is discussed in more detail below.

\section{Interface Standards Efforts}

The foundation for all efforts in the SIMA Program is the development, testing, and standardization of information specifications enabling communication among the multitude of software applications used in manufacturing industries. Even when software systems reside on the same computer, the present state of affairs is such that there is no guarantee that they can do anything more than send unintelligible data at one another. Still it stands to reason that, for example, the software used to design products should be able to provide design data to the software that is used to plan the manufacturing of the design. In reality engineers and other technical staff spend time recreating data in one software system that already exists in another, devising ad hoc data translation solutions, acquiring unique point-to-

2. High Performance Computing Systems; National Research and Education Network; Advanced Software Technology and Algorithms; Basic Research and Human Resources. 


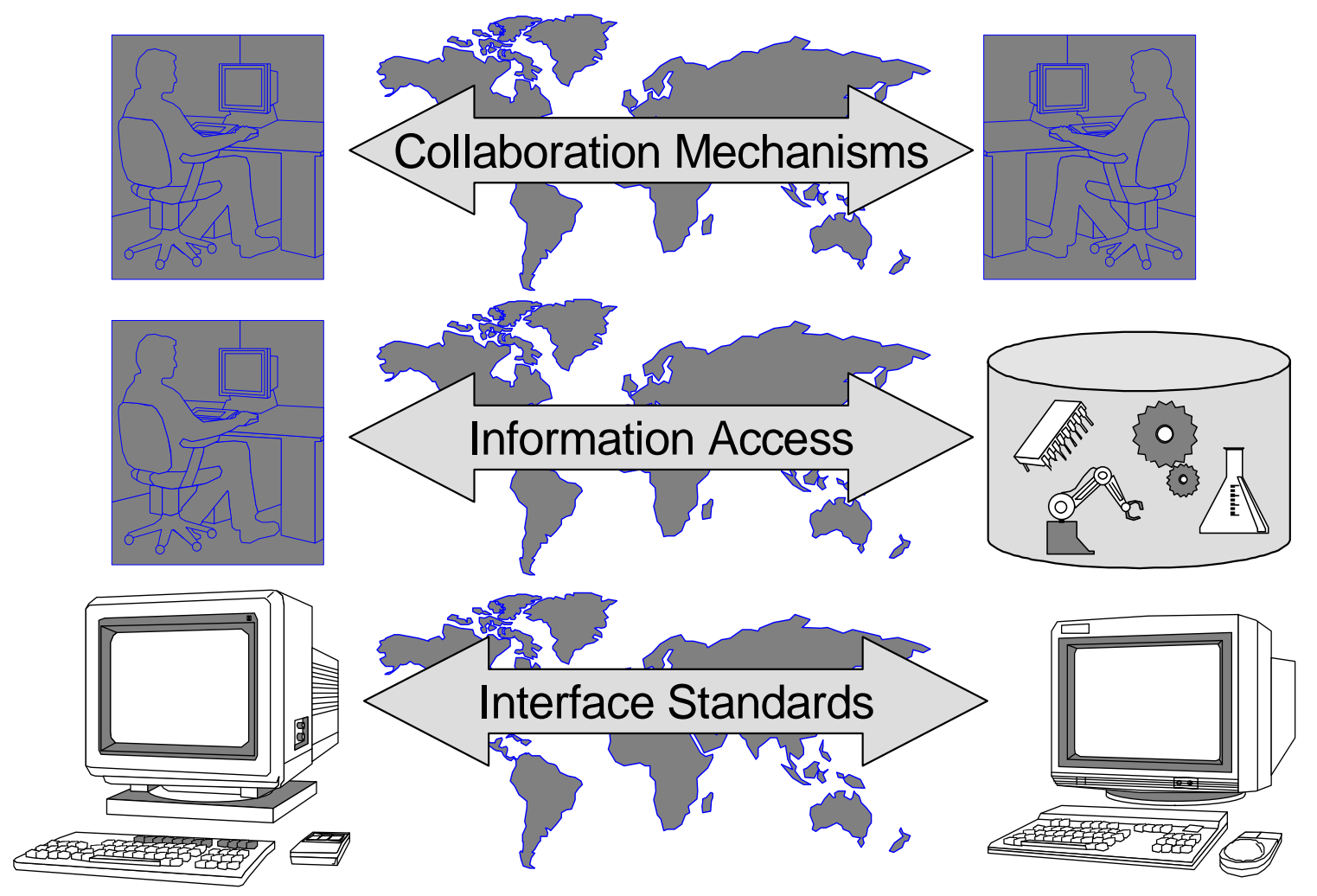

Figure 1. SIMA Technology Areas

point translation services, and identifying the errors that many of these work-arounds introduce. This lack of interoperability among software systems exists whether the systems are accessible to each other on the same intranet or on a wide-area network.

To address these interoperability issues, SIMA projects work in conjunction with industry collaborators to identify the requirements for the information that needs to be exchanged among engineering and manufacturing software applications. These requirements form the basis for the information models from which interface specifications are derived. With formal interfaces specifications in hand, prototype implementations of information exchange mechanisms can be developed to help validate the accuracy and utility of the specifications. These tests typically lead to pilot implementations in industry to further increase the robustness of the interoperability solution and to verify the business case for the solution (i.e., Is the prospective cost of the solution justified by the increase in efficiency? Is it less error-prone than existing methods?). With support from the manufacturing users and software developers, the interface specifications can be submitted to formal (or informal) standards developing organizations, e.g., the International Organization for Standardization (ISO) or the Object Management Group for further development and eventual standardization. These interoperability solutions have the effect of improving the degree of integration between particular software systems. 


\section{SIMA Overview}

Given that the process for developing interface specifications is fundamental to many SIMA efforts, the Program has documented a methodology for their development. The methodology is called the Initial Manufacturing Exchange Specification (IMES) process [10] and the output from the process is known as an IMES. IMESs are information interfaces which can take the following forms:

- an interface specification between a human and a software application.

- an interface specification between two or more software applications.

- a reference information repository specification.

The third type of IMES refers to a specification for the contents of a repository (typically a database) that is used to provide information to many activities, but the contents of which are updated by only a single process (typically an administration process).

\section{The IMES Process}

An IMES is developed through an industry review and consensus process and is accepted by the manufacturing community as a definitive solution to a particular interoperability problem. The IMES process involves seven phases. The execution of these phases need not occur sequentially -- some may overlap while others may occur in parallel. Figure 2 illustrates the seven phases showing how results from each phase are used by the others. The individual phases are described as follows:

Phase 1: Identify/Define Industry Need

The initial activity of IMES development is identifying and documenting an industry need, manufacturing scenario, or problem statement to define the scope and manufacturing domain of the proposed project. This need could be identified in several ways. Industrial collaborators are to be involved in defining this need.

\section{Phase 2: Analyze Requirements}

This IMES development phase consists of analyzing the current situation within the manufacturing scenario to understand current capabilities, prior attempts at a solution, and specific needs that must be accommodated in the proposed IMES solution. A requirements specification is the primary desired output from this project phase. Such a specification will enable widespread industry review of the detailed requirements that a solution must satisfy in a form that is understandable by the majority of the target manufacturing community.

\section{Phase 3: Design/Develop}

This IMES development phase consists of the actual design, development, and documentation of the proposed IMES technical solution that satisfies the requirements specified in the previous phase. The solution may consist of a combination of deliverable types, including information model(s), interface protocol(s), or process model(s), as required by the problem to be solved. The primary output of this phase is the initial version of the strawman proposal for external review.

Phase 4: Validate

A validation phase is required to ensure the completeness, validity, and usability of the proposed IMES solution. Validation activities may take several forms, including: prototype implementations, detailed walk-through with domain experts, or a comparison with known references. A proposed solution with demonstrated prototype implementations and validation test results makes a much stronger case for standardization. The documented test results (obviously based upon the prototype implementation, test environment, test suites, or other validation tools) are considered the primary output of this phase.

\section{Phase 5: Build Consensus}

By definition, an IMES is developed from an industry consensus viewpoint. Whereas most IMES development phases require some collaboration or interaction with industrial counterparts, this phase of IMES development requires interaction with a large segment of the target manufacturing community. This interaction can be accomplished through technical workshops, user group meetings, correspondence, or site visits. IMES development projects should 


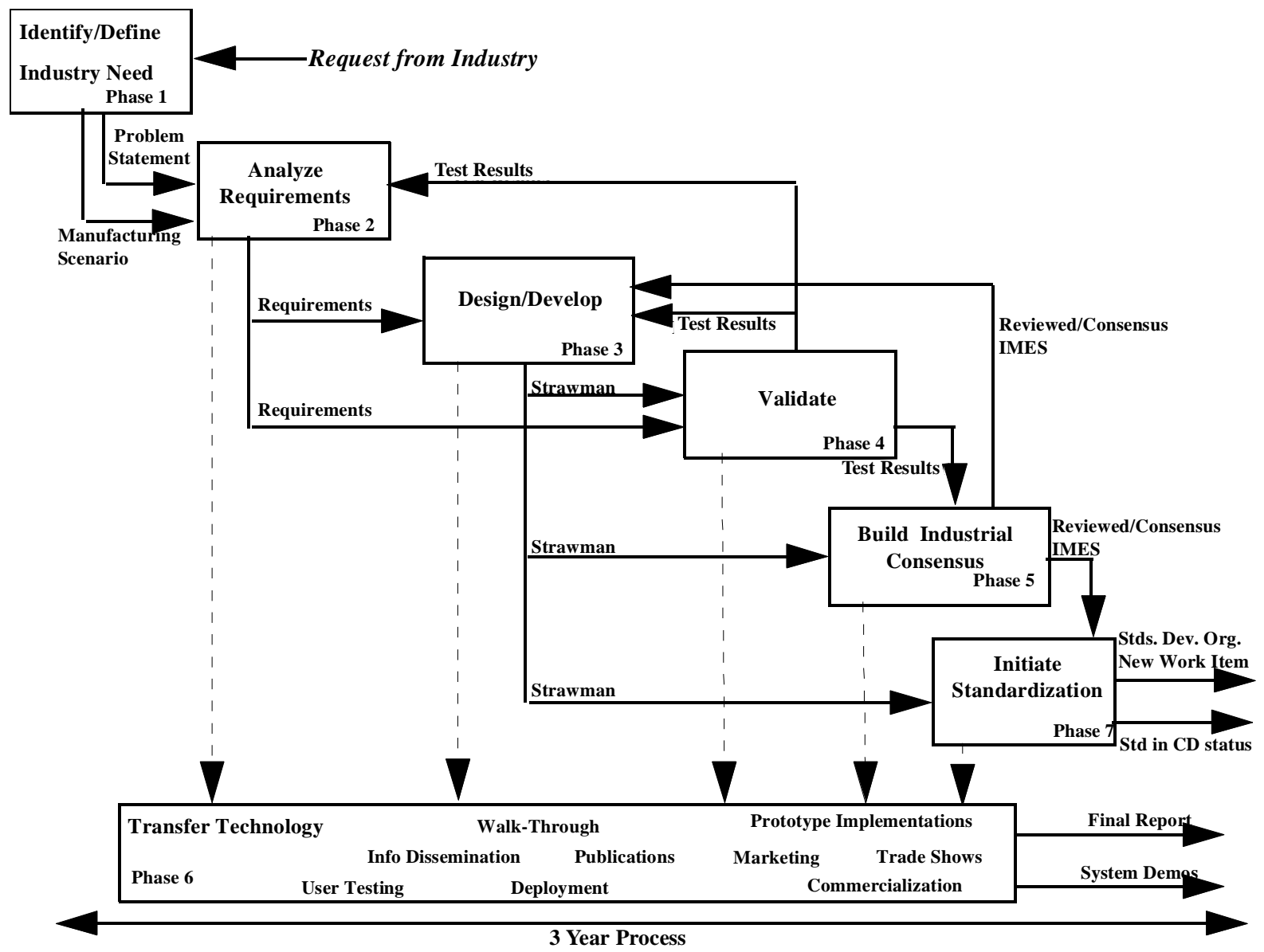

Figure 2. IMES Process Activities

endeavor to obtain and accommodate as much input and feedback from industry as possible in the proposed project solution. True consensus may never be reached. This project phase is deemed necessary, however, for positioning and delivering a quality-proposed strawman for standardization to an appropriate standards development organization. This phase is differentiated from the actual standardization process to allow and encourage other consensus-building activities without the potential constraints and procedures required by standards organizations. The primary deliverable of this phase is an updated Strawman IMES resulting from the consensus-building activities. In some cases, significant comments and suggestions may indicate the need for the project to iterate back to the IMES Design/ Develop Phase 3.

Phase 6: Transfer Technology

One of the primary missions of NIST is to provide technology transfer of NIST research results to industry. The SIMA Program supports this mission. IMES development efforts will include aspects of technology transfer to publicize, market, and transition project activities and results to industry or standards development organizations. Technology transfer should be an ongoing project activity. Various methods of technology transfer can be employed at the various stages of the IMES development effort to supply industry collaborators and the manufacturing community with current information. The primary deliverables for this phase consist of a final report and system demonstrations. 


\section{SIMA Overview}

Phase 7: Initiate Standardization

Since an IMES is a proposed standard solution to a manufacturing integration need, IMES development efforts must include interaction with appropriate standards development organizations to initiate this standardization. These activities may include attending standards meetings, participating on various standards committees, or writing project correspondence with standards development organization conveners. The objective of this phase is to initiate the proposed standards work (either as a new work item or modifications to existing standards/work items) to a point where it will be self-sustaining within the standards development organization.

\section{IMES Progress}

Six of the SIMA projects have identified a total of seventeen IMES development efforts. Table 1 depicts the IMESs under development and their stage of completion in the IMES process as of the end of FY98. The majority of the IMESs are in the initial phases of development reflecting the projects' efforts in working with industry collaborators to define the scope of the problems that can be addressed through development of these information interface specifications. 


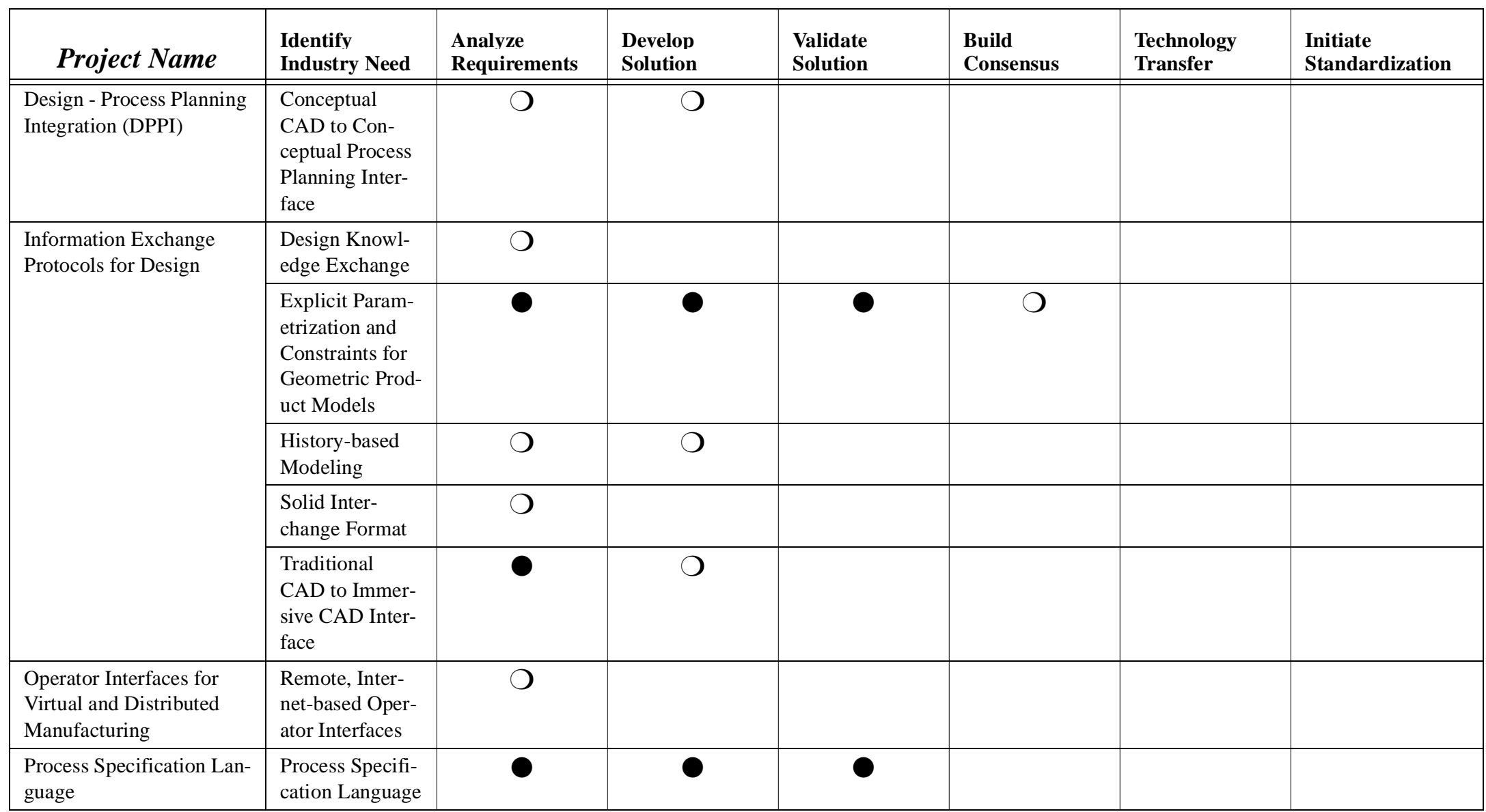

TABLE 1. IMESs by Project. The topic area for each IMES is listed in the Industry Need column. The $\bigcirc$ symbol indicates on-going work in the corresponding IMES phase, the symbol indicates work in that phase is complete, and no symbol at all indicates that no work has occurred in the corresponding IMES phase. 


\begin{tabular}{|c|c|c|c|c|c|c|c|}
\hline Project Name & $\begin{array}{l}\text { Identify } \\
\text { Industry Need }\end{array}$ & $\begin{array}{l}\text { Analyze } \\
\text { Requirements }\end{array}$ & $\begin{array}{l}\text { Develop } \\
\text { Solution }\end{array}$ & $\begin{array}{l}\text { Validate } \\
\text { Solution }\end{array}$ & $\begin{array}{l}\text { Build } \\
\text { Consensus }\end{array}$ & $\begin{array}{l}\text { Technology } \\
\text { Transfer }\end{array}$ & $\begin{array}{l}\text { Initiate } \\
\text { Standardization }\end{array}$ \\
\hline \multirow[t]{5}{*}{$\begin{array}{l}\text { Production and Product } \\
\text { Data Management Appli- } \\
\text { cations }\end{array}$} & $\begin{array}{l}\text { Discrete Event } \\
\text { Simulation for } \\
\text { Production Sys- } \\
\text { tems Engineer- } \\
\text { ing }\end{array}$ & 0 & & & & & \\
\hline & $\begin{array}{l}\text { Job, Schedule, } \\
\text { and Routing } \\
\text { Data Exchange }\end{array}$ & $\mathrm{O}$ & & & & & \\
\hline & $\begin{array}{l}\text { Plant Layout to } \\
\text { Simulation }\end{array}$ & 0 & $\bigcirc$ & & & & \\
\hline & $\begin{array}{l}\text { Shop Floor Sta- } \\
\text { tus }\end{array}$ & 0 & $\bigcirc$ & & & & \\
\hline & $\begin{array}{l}\text { Workstation } \\
\text { Level Process } \\
\text { Plan }\end{array}$ & 0 & $\mathrm{O}$ & & & & \\
\hline \multirow[t]{4}{*}{$\begin{array}{l}\text { Reference Model Archi- } \\
\text { tecture }\end{array}$} & $\begin{array}{l}\text { Generic Control } \\
\text { Node Shell } \\
\text { Specification }\end{array}$ & 0 & $\bigcirc$ & $O$ & $\bigcirc$ & $\bigcirc$ & \\
\hline & $\begin{array}{l}\text { Human Over- } \\
\text { sight Interface } \\
\text { Specification }\end{array}$ & 0 & $\bigcirc$ & $\mathrm{O}$ & & & \\
\hline & $\begin{array}{l}\text { Message Suite } \\
\text { Specifications }\end{array}$ & 0 & $\bigcirc$ & $\bigcirc$ & $\bigcirc$ & $\mathrm{O}$ & \\
\hline & $\begin{array}{l}\text { Plan Interface } \\
\text { Specifications }\end{array}$ & 0 & $\mathrm{O}$ & $\mathrm{O}$ & $\mathrm{O}$ & $\mathrm{O}$ & \\
\hline
\end{tabular}

TABLE 1. IMESs by Project. The topic area for each IMES is listed in the Industry Need column. The $\bigcirc$ symbol indicates on-going work in the corresponding IMES phase, the symbol indicates work in that phase is complete, and no symbol at all indicates that no work has occurred in the corresponding IMES phase. 


\section{Standards Progress}

Seven projects are contributing to the development or testing of information interfaces which are already in the formal standardization process (and hence are not considered IMESs). Specifications in these stages of development are typically those that have been in development for at least two years. Table 2 summarizes the twenty-two (22)

\begin{tabular}{|c|c|c|}
\hline Project Name & Standard Designation & $\begin{array}{l}\text { FY98 } \\
\text { Status }\end{array}$ \\
\hline $\begin{array}{l}\text { Design - Process Planning Inte- } \\
\text { gration (DPPI) }\end{array}$ & $\begin{array}{l}\text { ISO }^{\mathrm{a}} \text { 10303-213: Numerical control process plans for } \\
\text { machined parts }\end{array}$ & $\begin{array}{l}\text { Draft Inter- } \\
\text { national } \\
\text { Standard }\end{array}$ \\
\hline \multirow[t]{6}{*}{$\begin{array}{l}\text { Electronic Commerce for the } \\
\text { Electronics Industry (ECEI) }\end{array}$} & $\begin{array}{l}\text { IEC }^{\text {b }} \text { 62016: Design automation reference model - Core } \\
\text { conceptual model of the electronics domain }(C C M)\end{array}$ & $\begin{array}{l}\text { Committee } \\
\text { Draft }\end{array}$ \\
\hline & Electronic Design Interchange Format & $\begin{array}{l}\text { Interna- } \\
\text { tional Stan- } \\
\text { dard }^{\text {c }}\end{array}$ \\
\hline & $\begin{array}{l}\text { IPC }^{\mathrm{d}} \text { 2510: Generic Computer Aided Manufacturing } \\
\text { Descriptions for Printed Boards and Printed Board } \\
\text { Assembly (GenCAM) }\end{array}$ & $\begin{array}{l}\text { Industry } \\
\text { Standard }\end{array}$ \\
\hline & $\begin{array}{l}\text { IEC 61360: Standard data element types with associated } \\
\text { classification scheme for electric components }\end{array}$ & $\begin{array}{l}\text { Interna- } \\
\text { tional Stan- } \\
\text { dard }\end{array}$ \\
\hline & $\begin{array}{l}\text { ISO/IEC 10303-210: Electronic assembly, interconnect, } \\
\text { and packaging design }\end{array}$ & $\begin{array}{l}\text { Draft Inter- } \\
\text { national } \\
\text { Standard }\end{array}$ \\
\hline & IPC: Standard Recipe File Format ${ }^{\mathrm{e}}$ & $\begin{array}{l}\text { Industry } \\
\text { Standard }\end{array}$ \\
\hline $\begin{array}{l}\text { Enterprise Resource Planning } \\
\text { Interfaces (ERP-I) }\end{array}$ & $\mathrm{OMG}^{\mathrm{f}}$ : Enterprise Resource Planning & $\begin{array}{l}\text { Request for } \\
\text { Informa- } \\
\text { tion }\end{array}$ \\
\hline \multirow[t]{5}{*}{ Framework } & $\begin{array}{l}\text { ISO 10303-219: Exchange of dimensional inspection } \\
\text { information }\end{array}$ & $\begin{array}{l}\text { Prelimi- } \\
\text { nary Work } \\
\text { Item }\end{array}$ \\
\hline & OMG: Data Acquisition from Industrial Systems & $\begin{array}{l}\text { Request for } \\
\text { Proposals }\end{array}$ \\
\hline & OMG: Manufacturing Execution Systems & $\begin{array}{l}\text { Request for } \\
\text { Informa- } \\
\text { tion }\end{array}$ \\
\hline & $\begin{array}{l}\text { OMG: Product Data Management Enablers Specifica- } \\
\text { tion }\end{array}$ & Adopted \\
\hline & OMG: Release for Production & $\begin{array}{l}\text { Request for } \\
\text { Proposals }\end{array}$ \\
\hline \multirow{2}{*}{$\begin{array}{l}\text { Standard for the Exchange of } \\
\text { Product Model Data (STEP) } \\
\text { Conformance and Interopera- } \\
\text { bility Testing }\end{array}$} & $\begin{array}{l}\text { ISO 10303-302: Abstract test suite: Associative draugh- } \\
\text { ting }\end{array}$ & $\begin{array}{l}\text { Working } \\
\text { Draft }\end{array}$ \\
\hline & $\begin{array}{l}\text { ISO 10303-303: Abstract test suite: Configuration con- } \\
\text { trolled 3D designs of mechanical parts and assemblies }\end{array}$ & $\begin{array}{l}\text { Working } \\
\text { Draft }\end{array}$ \\
\hline
\end{tabular}

TABLE 2. Standards Efforts by Project 


\section{SIMA Overview}

\begin{tabular}{|l|l|l|}
\hline \multicolumn{1}{|c|}{ Project Name } & Standard Designation & $\begin{array}{l}\text { FY98 } \\
\text { Status }\end{array}$ \\
\hline \hline $\begin{array}{l}\text { STEP for the Process Plant } \\
\text { Industries }\end{array}$ & ISO 10303-227: Plant spatial configuration & $\begin{array}{l}\text { Draft Inter- } \\
\text { national } \\
\text { Standard }\end{array}$ \\
\cline { 2 - 3 } & $\begin{array}{l}\text { ISO 10303-231: Process engineering data: Process } \\
\text { design and process Specification of major equipment }\end{array}$ & $\begin{array}{l}\text { Committee } \\
\text { Draft }\end{array}$ \\
\cline { 2 - 3 } & $\begin{array}{l}\text { ISO 10303-327: Abstract test suite: Plant spatial config- } \\
\text { uration }\end{array}$ & $\begin{array}{l}\text { Pre-work- } \\
\text { ing Draft }\end{array}$ \\
\cline { 2 - 3 } & $\begin{array}{l}\text { ISO 10303-331: Abstract test suite: Process engineering } \\
\text { data: Process design and process Specification of major } \\
\text { equipment }\end{array}$ & $\begin{array}{l}\text { Pre-work- } \\
\text { ing Draft }\end{array}$ \\
\hline \multirow{5}{*}{$\begin{array}{l}\text { Standards for Exchange of } \\
\text { Chemical Reference Data }\end{array}$} & $\begin{array}{l}\text { ASTM }{ }^{\mathrm{g}} \text { E1947-98: Standard Specification for Analytical } \\
\text { Data Interchange Protocol for Chromotographic Data }\end{array}$ & $\begin{array}{l}\text { National } \\
\text { Standard }\end{array}$ \\
\cline { 2 - 3 } & $\begin{array}{l}\text { ASTM: Laboratory Equipment Communication Inter- } \\
\text { face Specification }\end{array}$ & $\begin{array}{l}\text { Draft Stan- } \\
\text { dard }\end{array}$ \\
\cline { 2 - 3 } & $\begin{array}{l}\text { NCCLS } \text { AUTO3-P: Communications with Automated } \\
\text { Clinical Laboratory Systems, Instruments, Devices, and } \\
\text { Information Systems }\end{array}$ & $\begin{array}{l}\text { Draft Stan- } \\
\text { dard }\end{array}$ \\
\hline
\end{tabular}

TABLE 2. Standards Efforts by Project

a. The International Organization for Standardization (ISO) is a formal standards developing organization.

b. The International Electrotechnical Commission (IEC) is a formal standards developing organization.

c. This specification is continuing to develop under the auspices of the Electronic Industries Alliance, an industry trade association. Existing versions of the specification have been adopted as national standards by the American National Standards Institute and as international standards by the IEC.

d. The Institute for Interconnecting and Packaging Electronic Circuits (IPC) is an industry trade association.

e. This specification was developed under the auspices of the Surface Mount Equipment Manufacturer's Association (SMEMA). SMEMA has since merged with the IPC, where the specification continues to evolve.

f. The Object Management Group (OMG) is an industry trade association..

g. The American Society for Testing and Materials (ASTM) is a formal standards developing organization.

h. The National Committee for Clinical Laboratory Standards (NCCLS) is a formal standards developing organization.

standards to which the projects have been contributing.

As these standards become more fully deployed in industry it will become practical to assess the effects they are having on specific interoperability problems, and to assess the NIST contributions to those benefits. In the interim, the SIMA Program has already initiated efforts that will lay the foundation for future assessments. One recently completed effort is a study of the interoperability costs incurred by companies in the U.S. automotive supply chain [11]. That study identified annual costs of one billion dollars owing to problems in the exchange of technical data amongst the numerous engineering and manufacturing software applications used by those companies. The costs identified included expenditures for additional engineering labor to fix errors resulting from inaccurate data exchanges and time-to-market delay costs. The study indicated that these costs were likely to be representative of the interoperability costs experienced in other transportation manufacturing industries as well (e.g., aerospace). The information interfaces and interoperability solutions resulting from the SIMA Program are expected to play a significant role in reducing the interoperability costs that manufacturers are incurring. 


\section{Information Access Efforts}

The Internet provides an information access capability that continues to evolve and grow with each passing month. Information resources are now available at the user's desktop with only a few keystrokes. With many thousands of information resources however, users are potentially overwhelmed, unable to find what is needed, and unable to use resources efficiently if found because of incompatabilities. Moreover, the veracity of information found on the Internet is frequently called into question. Yet the scientists and engineers responsible for creating new products and processes must have reliable, accurate, and timely access to technical data of known quality in order for their efforts to be successful.

The SIMA Program effort in providing Internet access to technical data is addressing such issues. This effort builds on NIST's well-respected Standard Reference Data Program (SRDP), which serves the U.S. technical community by collecting published technical data and determining their reliability. NIST's SRDP offers evaluated scientific data collections that together represent the world's largest collection of evaluated scientific data. These data collections are drawn from the more than 1,000,000 technical papers reporting research published each year in the fields of chemistry, physics, materials science, and engineering. The information in those papers includes numeric data used by U.S. scientists and engineers in their daily work of research, testing, and product/process development. The private sector does not offer the evaluated data services performed by NIST because preparation of reliable scientific databases is not a commercially viable activity. Reliable data requires evaluation, the assessment of data accuracy by expert scientists and engineers. With its strong technical staff, NIST sets the world benchmark for evaluation capability.

The SIMA Program adds value to NIST's existing SRDP effort by making these data collections available to any user with an Internet connection. This not only improves the penetration of these data in the technical community but also ensures that the data the users are depending on are the latest available. In addition, the evolving technical capabilities of internet browsers enable new mechanisms for interacting with these data collections. These include innovative search capabilities based on graphical input from users, interactive manipulation of data graphs, as well as outputs from the data collections that can be directly incorporated into the software on the user's local computer. Seven SIMA projects are involved in these SRDP efforts and have demonstrated considerable success as evidenced by the significant usage of their online data collections by industrial sites.

The SIMA Program also continues to explore related needs for online access to technical information as well as online access to technical capabilities. Other areas of active work include efforts to make interactive versions of widely used NIST reference books in statistics and mathematical functions available on the Internet. Another new effort is making NIST test services for manufacturing software available on the Internet. While the technical community is reaping immediate benefits from these types of capabilities, we expect that the continuing evolution of both Internet technologies and the information interfaces developed in the other parts of the SIMA program will together provide even greater information access benefits in the future.

\section{Collaboration Mechanisms}

"Research is conducted in virtual laboratories in which scientists and engineers can routinely perform their work without regard to physical location - interacting with colleagues, accessing instrumentation, sharing data and computational resources, and accessing information in digital libraries."

President's Information Technology Advisory Committee Interim Report To The President, August 1998

The concept of a collaboratory (collaboration + laboratory) is attributed to Dr. William Wulf, who explored the idea in a white paper (1989) while he was the assistant director of the National Science Foundation's Directorate for Computer and Information Science and Engineering. His vision is repeated in the above report to the President, which among other things, recommends transforming the way research is performed. A variety of technologies need to be more fully developed in order to realize this vision. While the interface standards and information access efforts of the SIMA Program will help to enable this vision, the efforts most relevant to that vision are those in the Program's 


\section{SIMA Overview}

projects in collaboration mechanisms. Here, projects are developing the components of a collaboratory environment that will enable NIST researchers and their partners to share information, work together remotely, and in so doing improve the nature of computer-supported collaborations for manufacturing research.

NIST is working to deploy a cutting-edge manufacturing collaboratory as a neutral environment in which other industrial and government partners can cooperate and learn, and in which NIST can begin the active development work necessary to support the next generation of standards for using collaboration technology to support manufacturing. The manufacturing collaboratory provides an environment to test the applicability of human-centered design when applied to manufacturing requirements. Manufacturing partners benefit through early access to frontier collaboration technologies as well as to methodologies for evaluating the impact of these technologies. This exposure is likely to offer valuable insights into how to produce and introduce usable and useful systems for long-distance collaboration. In a broader sense, the manufacturing engineering community will benefit from the existence of a collaboratory testbed. In particular, the testbed will create a new forum for the exchange of technical information among academic, industry, government, and standards bodies. The ultimate goal of the effort will be to create a selfsustaining "critical mass" of expertise and experience with collaboratories, to be drawn upon by projects at NIST, manufacturing researchers, and practitioners.

Looking to the future we can expect that collaboration technologies will lead to new paradigms for the interactions that take place amongst users and amongst manufacturing software applications - indeed in all likelihood there will be new classes of software applications used in manufacturing in this context. The results will undoubtedly be new requirements for information interfaces addressing whole new interoperability problems. Hence the SIMA Program looks to the results of the efforts in collaboration mechanisms as a source of requirements for the other two focus areas of the Program.

\section{$\underline{\text { SIMA Vision }}$}

The vision for the SIMA Program is that of product realization environments based on seamless communication of information among business enterprises, people, software systems, and hardware systems. It is our belief that the three major technology areas in the Program - interface standards, information access, and collaboration mechanisms - together cover most, if not all, of the significant technical challenges preventing a seamless environment for product realization. Decomposing those technology areas a bit further leads to a picture like that shown in Figure 3.

Underlying the work of the Program is foundational knowledge of how to integrate systems, drawn from information theory, software engineering, systems engineering, and the like. This foundational knowledge manifests itself as methodologies for developing robust, extensible information-interface specifications and methodologies for testing implementations of those specifications. The importance of these testing methodologies can not be overstated, since the confidence in the implementation of the specification (and therefore its usefulness as an interoperability solution) is related directly to the confidence in the testing methods.

Based on this foundation of integration "know-how," we then have SIMA projects involved in the solution of particular interoperability problems; sometimes from the outset (as in the projects developing IMES's), and sometimes participating at later stages (as in the projects participating in standards development and deployment). The projects targeted at specific problem areas continue to add to the foundational knowledge for systems integration. Hence the short-term benefits of the Program manifest themselves as solutions to specific interoperability problems. But the lasting impact of the Program may well be the legacy of general methods and practices for development and testing of interoperability solutions. 


\begin{tabular}{|c|c|c|c|}
\hline $\begin{array}{l}\text { Collaboration } \\
\text { Mechanisms }\end{array}$ & $\begin{array}{l}\text { Information } \\
\text { Access }\end{array}$ & $\begin{array}{c}\text { Interoperable } \\
\text { Applications }\end{array}$ & $\begin{array}{c}\text { Seamless } \\
\text { Product Realization } \\
\text { Environment }\end{array}$ \\
\hline \multicolumn{3}{|c|}{ Testing of Commercial Interoperability Solutions } & \multirow{4}{*}{$\begin{array}{c}\text { Advancing } \\
\text { Interoperability }\end{array}$} \\
\hline Standar & of Interope & Solutions & \\
\hline \multicolumn{3}{|c|}{ Validation of Candidate Interoperability Solutions } & \\
\hline \multicolumn{3}{|c|}{ Development of Models \& Protocols (IMES's...Standards) } & \\
\hline \multicolumn{3}{|c|}{ Specification \& Testing Methods } & \multirow{2}{*}{$\begin{array}{l}\text { Integration } \\
\text { Foundations }\end{array}$} \\
\hline \multicolumn{3}{|c|}{ Science of Manufacturing Systems Integration } & \\
\hline
\end{tabular}

Figure 3. The SIMA Vision

\section{Project Accomplishments}

The following descriptions provide summaries of each SIMA Program technical project. Project summaries are organized by program environment element (see Appendix A for a description of the organization of projects). Each project summary provides a brief description of objectives, accomplishments, and collaborations. Detailed information on any project may be obtained by contacting the principal investigator listed for that project. 


\section{Interface Standards Project Summaries}

\section{IS1: Application Protocol Development Environment (APDE)}

Principal Investigator: Joshua Lubell

Telephone: (301) 975 - 3563

E-mail: joshua.lubell@ nist.gov

The APDE project is working to accelerate the development of ISO 10303 (informally known as the STandard for the Exchange of Product model data, or "STEP") [12] by aiding application protocol (AP) developers in creating STEP specifications of higher quality at lower cost. The APDE project is meeting these objectives by providing an environment for authoring STEP specifications using the Standard Generalized Markup language (SGML) [13] as well as by providing web-based access to STEP specifications and software tools. STEP specifications submitted to ISO must meet specified criteria for document formatting and integration with existing STEP building block specifications. Application protocols

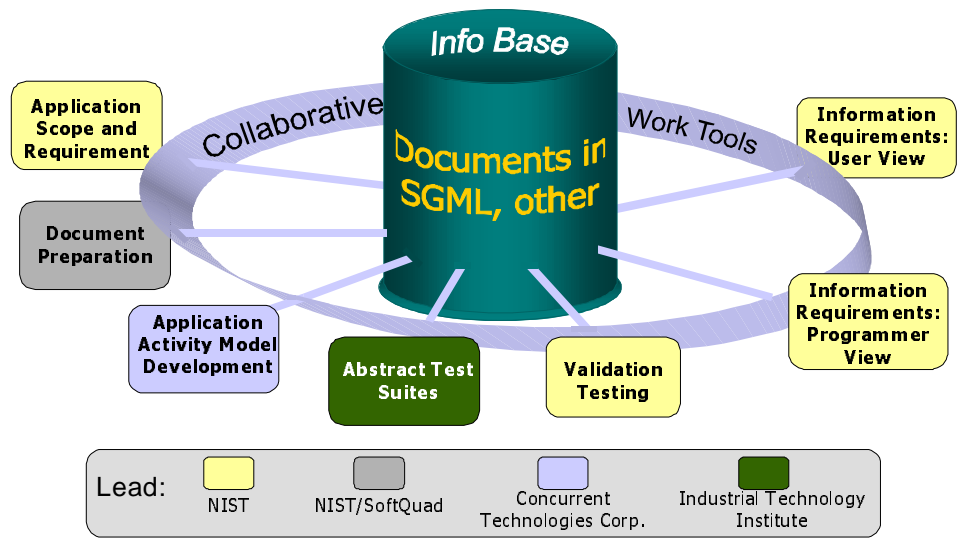
(AP) usually require extensive rework before they are allowed to progress through the standards process. Current practices used for

APDE components AP development require extraordinary labor expenditures on behalf of AP developers to create AP documents. While AP developers may use some software tools to help them accomplish their AP development tasks, the tools work independently, are not integrated, and have not been customized specifically for the purpose of AP development. By providing an SGML-based environment for STEP specification authoring, NIST is increasing the ability of AP developers to reuse relevant portions of existing specifications, to manage complex standards documents, and to improve the quality of the finished standard product.

Significant FY98/97 Accomplishments

- Supported the Draft International Standard publication of ISO/IEC 10303-210 [14] (Electronic Assembly, Interconnect, and Packaging Design), a 3600 page STEP application protocol utilizing the APDE SGML authoring environment.

- Provided an Internet-accessible, publicly available interface to software tools enabling the processing of STEP information models and data files.

- Developed and deployed a software tool enabling the conversion of SGML-tagged STEP specifications into Hypertext Markup Language (HTML) making them viewable by any Internet browser.

- Provided an Internet browser accessible resource enabling STEP AP developers to search for and view STEP specification building blocks ("units of functionality"). 


\section{Collaborations}

- Boeing, for development of ISO/IEC 10303-210.

- Concurrent Technologies Corporation, for joint development of AP software tools and methods.

- Delphi Delco, for development of ISO/IEC 10303-210.

- Industrial Technology Institute, for development of AP software tools.

- PDES Inc., for development of ISO/IEC 10303-210.

- PlantSTEP, for evaluation of APDE-developed methods and software.

- Rockwell Collins, for development of ISO/IEC 10303-210.

- SoftQuad, Inc., for customization of SGML editing tools for the STEP community.

- STEP Tools Inc., for use of their software tools in the development of the APDE.

- U.S. Army, for development of ISO/IEC 10303-210.

- University of Darmstadt, for development of SGML document type definitions. 


\section{$\underline{\text { IS2: Design - Process Planning Integration (DPPI) }}$}

Principal Investigator: Shaw Feng

Telephone: (301) 975 - 3551

E-mail: shaw.feng@nist.gov

The objective of this project is to enable interoperability among the activities of conceptual design, detailed design, conceptual process planning, detailed process planning, and cost estimating. To achieve this, the project is working towards developing interfaces among the software applications used in those activities, reusing existing interface specifications where available, and validating prototype interoperability solutions.

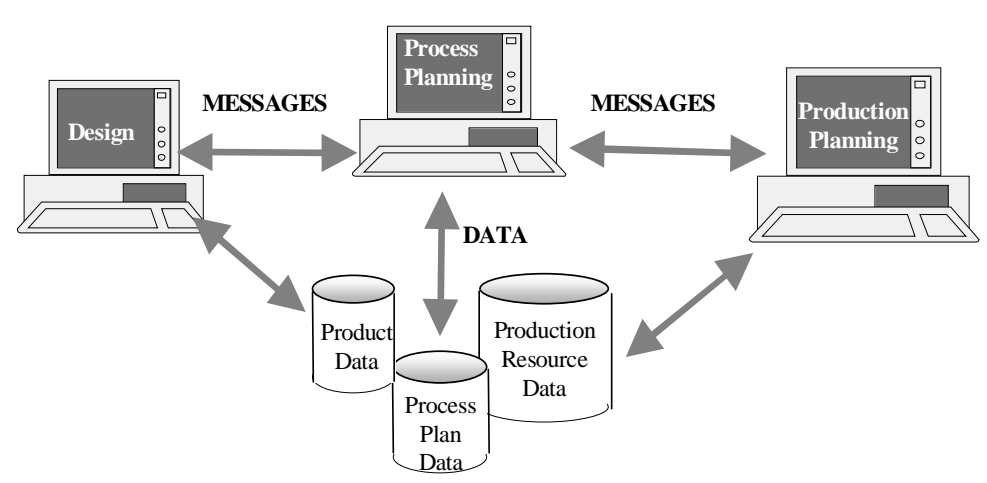

Interactions between engineering design and process planning systems

\section{Significant FY98/97 Accomplishments}

- Acquired commercially available, knowledge-based design systems, modeling systems, and process planning systems for use in assessing existing interoperability issues and potential solutions.

- Developed a design/manufacturing model of a gearbox and a conceptual design/process planning system for use in testing evolving interoperability solutions.

- Presented a project overview at the Artificial Intelligence and Manufacturing Research Workshop in Albuquerque, New Mexico, 1998.

- Published a report assessing the coverage of the STEP Application Protocol Process Planning for Numerical Controlled Machining (ISO 10303-213) [15].

- Assisted with the resolution of ballot comments for ISO 10303-213 and thereby enabled the promotion of the document to Final Draft International Standard status.

- Developed and demonstrated a prototype implementation of ISO 10303-213 using commercial process planning and numerical control software systems.

\section{$\underline{\text { Collaborations }}$}

- CAMAX, for validation of numerical control (NC) programming application information requirements using their NC programming system, SmartCAM.

- CIMx, for validation of process planning application information requirements using their process planning system, CS/CAPP.

- CNC Software, Inc., for validation of NC programming application information requirements using their system, Mastercam.

- Institute for Advanced Manufacturing Sciences (IAMS), for work on a pilot implementation of ISO 10303-213.

- PDES Inc., for coordination of the ballot process on ISO 10303-213 and to participate in abstract test suite development.

- Technologies Enabling Agile Manufacturing (TEAM), for definition of requirements for integrated process planning.

- University of Maryland, for investigation of requirements for process specification languages. 


\section{IS3: Electronic Commerce for the Electronics Industry (ECEI)}

Principal Investigator: James St. Pierre

Telephone: (301) 975 - 4124

E-mail: jimstp@nist.gov

The objective of this project is to contribute to the technical development of the neutral product data exchange specifications and the component information infrastructure for the electronics industry. Towards this goal, the project strives to resolve conflicts among competing and conflicting standardization efforts within the electronics industry. Project staff work with industry and other government laboratories to promote the transfer of technical information among the manufacturers of electronic parts and those who need parts for the design, manufacture, and repair of electronic systems. These efforts include research-based prototype development as well as specification development.

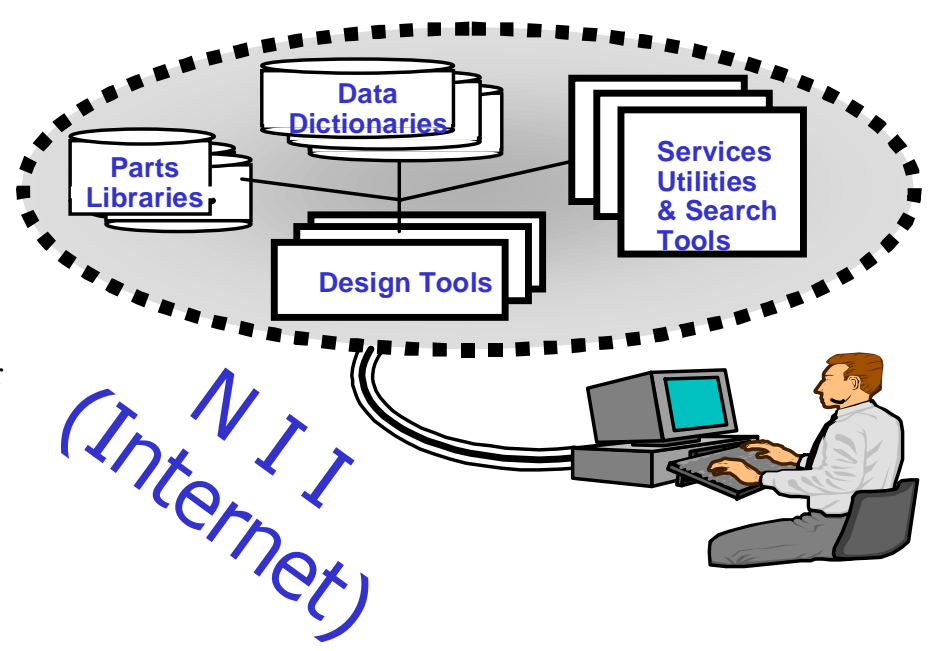

Engineering of electronic products via the internet

Some of the technical areas addressed by this project are: the fundamental terminology used to describe components, the organization of the component data and metadata, and the ability to access this data and incorporate it into the lifecycle of a design. Assisting in the development of standards in this domain is crucial in order for U.S. electronics manufacturers to take advantage of the global marketplace. Industry and standards groups in both Japan and Europe are working actively on ECEI-related projects. This project will work with these groups to minimize overlapping standards development and to ensure interoperability between U.S. ECEI data and that of other countries.

\section{Significant FY98/97 Accomplishments}

- Developed a prototype testing environment for implementations of the SEMATECH Computer Integrated Manufacturing (CIM) Framework. The environment can be viewed at http://megavolt.eeel.nist.gov/CIM.html.

- Developed a prototype dictionary translation tool enabling the conversion of electronic component information into the electronic component terminology format defined by the Silicon Integration Initiative. This capability was demonstrated at the Design Automation Conference in Anaheim, California, in June 1998.

- Provided key technical contributions to the development of the STEP Application Protocol for Electronic Assembly, Interconnect, and Packaging Design (ISO/IEC 10303-210) [14].

- Provided key technical contributions to the development of the "Standard Recipe File Format" under development by the Surface Mount Equipment Manufacturers Association and the Georgia Institute of Technology.

- Co-hosted a workshop on Electronic Commerce of Component Information (July 1998) with one result being a plan to initiate an international interoperability pilot test involving Europe and Japan.

- Conducted a joint Defense Advanced Research Projects Agency (DARPA)/NIST/Electronics Design Automation (EDA) Industry Council workshop on design reuse and intellectual property cores (January 1997). 


\section{Collaborations}

- Electronic Industries Association, for resolution of issues on the Electronic Design Interchange Format (EDIF).

- Electronic Equipment and Component CALS (E-CALS), for development and deployment of electronic component information technologies.

- Component Information Representation European Project (CIREP), for evaluation of component dictionary tools.

- Georgia Institute of Technology, for use of their board assembly facility and development of software tools testing evolving interchange specifications.

- IGES Data Analysis, for development of electronic product information viewer specifications.

- National Electronics Manufacturing Initiative, for development of mechanisms enabling integration of electronics manufacturing equipment.

- Mitta Technology Group, for commercialization of the NIST-developed CIM Framework testing environment.

- Naval Research Laboratory, for analysis of standards issues in the Microwave \& Millimeter-wave Advanced Computational Environment (MMACE) Program.

- PDES Inc., for development of ISO 10303-210.

- SEMATECH, for validation of the CIM Framework.

- Silicon Integration Initiative (formerly CAD Framework Initiative), for development of online electronic component databooks standards and software testing tools.

- Surface Mount Equipment Manufacturers Association (SMEMA), for development of interface specifications enabling control of printed circuit board manufacturing equipment.

- Texas Instruments, for development of electronic component dictionary tools.

- Viewlogic Systems Inc., for analysis of electronic component data requirements in electronic engineering and design software.

- Virtual Socket Interface Alliance, for development of software tools helping to resolve terminology issues in the electronics industry. 


\section{IS4: Enterprise Resource Planning Interfaces (ERP-I)}

Principal Investigator: Mary Beth Algeo

Telephone: (301) 975 - 2888

E-mail: mary.algeo@nist.gov

Principal Investigator: Edward Barkmeyer

Telephone: (301) 975 - 3528

E-mail: edward.barkmeyer@nist.gov

The objective of this project is to investigate the need for standards among the software systems used in Supply Chain Management (SCM), Enterprise Resource Planning (ERP) and the other manufacturing software systems that may interface with those systems such as Product Data Management (PDM), Manufacturing Execution Systems (MES), and electronic commerce systems. The approach that the project will follow will be to identify the stateof-the-practice with respect to the enterprise activities making use of these systems, investigate the availability of evolving standards in these areas, identify a framework in which these multiple standards co-exist, identify gaps in the standards efforts, and identify NIST activities that can address those gaps.

Significant FY98/97 Accomplishments

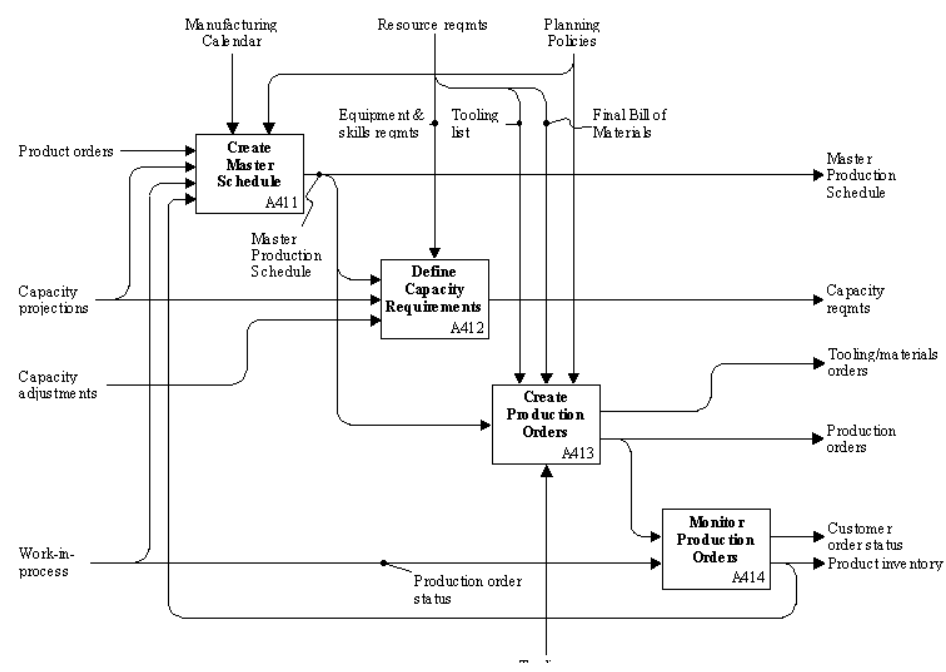

Development of production plan

- Developed a draft model of enterprise activities, the information resources employed in those activities, and the decision systems supporting those activities.

- Participated in the development of the Object Management Group's Manufacturing Domain Taskforce Release for Production Request for Proposals.

- Developed a state-of-the-art assessment of supply chain management practices.

Collaborations

- Advanced Manufacturing Research, for establishing a forum in which to uncover standards-related issues.

- Defense Advanced Research Projects Agency, for work with the Affordable Multi-Missle Manufacturing Program (AM3) on supply chain issues in missle manufacturing.

- Gartner Group, for identification of industry and market analysis information.

- Indian Institute of Management, for research in enterprise resource management.

- National Industrial Information Infrastructure Protocols (NIIIP) Program, for investigation of supply chain issues in missle manufacturing.

- Supply Chain Council, for modeling of intracompany and intercompany supply chains. 


\section{IS5: Information Exchange Protocols for Design}

Principal Investigator: Ram Sriram

Telephone: (301) 975 - 3507

E-mail: ram.sriram@nist.gov

The objective of this project is to develop appropriate standards and protocols for interoperability of design with other engineering tasks, such as process planning and production engineering. Specific objectives of the project are as follows:

- to enhance ISO 10303 (informally known as the STandard for the Exchange of Product model data, or "STEP") [12] for the capture and exchange of parametric, constraintbased and feature-based models such as are generated by all major

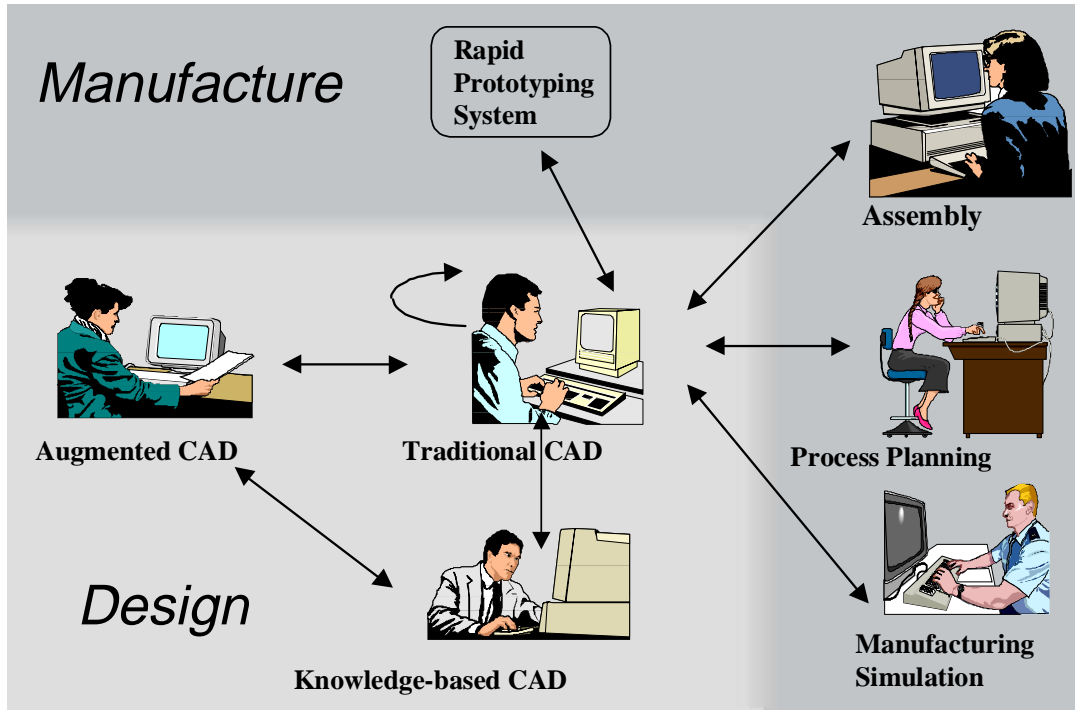
modern computer-aided

Interactions between design process and manufacturing design (CAD) systems.

- to develop a more robust mechanism for the exchange of design data between CAD systems and rapid prototyping systems.

- to address integration issues of linking assembly-oriented tools (e.g., virtual assembly and design-for-assembly) to traditional CAD systems.

- to explore the development of engineering ontologies for communication of design knowledge information.

Significant FY98/97 Accomplishments

- Chaired meetings of the ISO TC184/SC4 Parametrics Working Group in Canada, the United Kingdom, California, Italy, Florida, and Germany as well as special workshops in Germany and Maryland.

- Published a study of proposals for standard computer-aided design system application programming interfaces as a precursor to standardizing such capabilities in STEP.

- Presented seminars on STEP Parametrics and related work at numerous company sites, universities, and conferences.

- Conducted an industry workshop on Measurements and Standards Issues in Rapid Prototyping in Oct. 1997 with partipation by numerous rapid prototyping system vendors and users; a white paper resulting from the workshop is being used to catalyze future efforts.

- Presented seminars on rapid prototyping measurement and standards issues at several conferences and industry events.

- Developed an initial data planning model for a solid interchange format for rapid prototyping systems based on existing and enhanced STEP models.

- Developed a preliminary function-assembly-behavior model which conceptually integrates function, form, and behavior models with assembly models. 
- Developed an initial specification for the Open Assembly Design Environment (OpenADE) in the Unified Modeling Langage (UML).

- Conducted an industry workshop at NIST in November of 1997 to gather requirements for exhange of knowledge and design intent among engineering applications.

Collaborations

- Allied Signal, for development of ISO TC184/SC4 parametrics representations.

- Boeing, for investigation of knowledge-based system interchange issues.

- Black and Decker, for investigation of product development scenarios and as a source of data.

- Defense Advanced Research Projects Agency, for joint work in the Enabling Next Generation Design (ENGEN) project, the Rapid Design Exploration and Optimization (RaDEO) project, and the Solid Freeform Fabrication project.

- D.H. Brown Associates' Open CAD Architecture Interface project, for development of feature-based representation specifications.

- General Engineering and Systems Analysis Co., for investigation of tolerancing and design issues.

- George Washington University, for investigation of computer-assisted design (CAD) and virtual reality integration issues.

- International Business Machines Co., for investigation of tolerancing issues in assembly representations.

- Knowledge-based Organization, for investigation of knowledge-based system interchange issues.

- Knowlege Technologies Inc., for investigation of knowledge-based system interchange issues.

- National Center for Manufacturing Sciences, for work with the Rapid Prototyping Technology Advancement Program towards gathering industry requirements and development of an industry roadmap.

- Nihon Unisys, for development of ISO TC184/SC4 parametrics representations.

- Paccar Inc., for investigation of CAD and virtual reality integration issues.

- Rapid Prototyping Association of the Society of Manufacturing Engineers, to investigate industry requirements and potential standards development activities.

- Stanford University, for investigation of data representations suitable for the solid interchange format.

- Syracuse University, for investigation of tolerancing issues in assembly representations.

- Technosoft Inc., for investigation of knowledge-based system interchange issues.

- University of Maryland, for investigation of integration between knowledge-based design and traditional CAD.

- University of Michigan, for investigation of respresentations of materials in rapid prototyping interchange.

- University of Rochester, for investigation of tolerancing issues in assembly representations.

- Washington State University, for investigation of CAD and virtual reality integration issues.

- Wichita State University, for investigation of CAD and virtual reality integration issues.

- Xerox Corp., for investigation of tolerancing issues in assembly representations. 


\section{IS6: Internet Commerce for Manufacturing}

Principal Investigator: Barbara Goldstein

Telephone: (301) 975 - 2304

E-mail: barbara.goldstein@nist.gov

The objective of this project, initiated in 1998, is to work with industry to create an environment where small manufacturers of mechanical and electronic components may participate competitively in virtual enterprises for manufacturing printed circuit assemblies (PCAs). In particular, this project will identify and overcome some of the manufacturing information technology problems that exist at the intersection of manufacturing and electronic commerce systems. To accomplish this objective, the project will:

- Gather and document industry requirements and current practice through a series of scenario development/strategy workshops. This information will be used to develop or select an activity model to guide the project, and to publish a business case to document the economic motivation for migrating towards

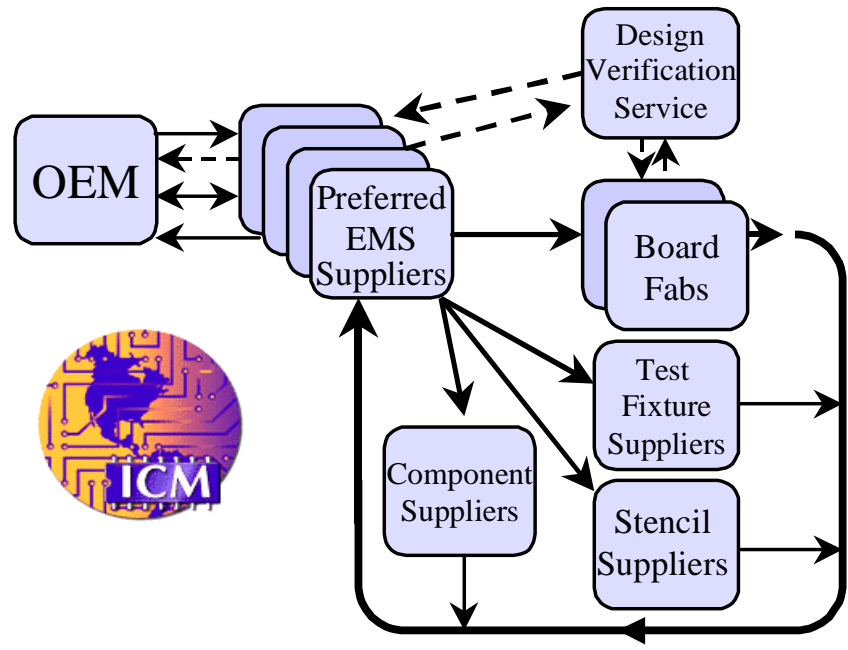

Architecting the Electronics Manufacturing Supply Chain Internet commerce in the PCA industry.

- Identify and develop needed standards. A standards roadmap will be published to reflect the availability and status of standards for the exchange of both technical and business information. Team members will participate in the development and testing of those standards identified as critical to the migration towards Internet commerce, such as the Institute for Interconnecting and Packaging Electronic Circuit (IPC) Generic Computer Aided Manufacturing (GENCAM) format and the Surface Mount Equipment Manufacturers Association (SMEMA) Standard Recipe File Format (SRFF).

- Establish an Internet Commerce for Manufacturing testbed at NIST. A testbed will be established at NIST to validate the ability to use standards identified in the standards roadmap to address the industry needs identified in the business case and requirements document. Industry and academic partners will serve as demonstration nodes within the scenario.

- Transfer results to industry, academia and other agencies. The team will participate in a variety of in-house and conference demonstrations. The business case, standards roadmap, and proceedings from all workshops will be published and disseminated.

Significant FY98/97 Accomplishments

- Conducted multiple industry workshops to review the project's strategy, to develop scenarios, and to develop an architecture. An architecture advisory board was established with participation by several industry and academic experts.

- Released an initial version of a GENCAM conformance test module which is available for download from the IPC GENCAM website (http://www.gencam.org/software/ctm/ctmupload.html). The test module was demonstrated at several industry trade shows.

- Developed preliminary versions of an electronic-commerce scenario document for manufacturers and a standards roadmap. 


\section{Collaborations}

- Automata Design Inc., for implementation and testing of GENCAM and prototyping of web-based manufacturing services.

- CommerceNet, for work with the eCo system project in development of electronic commerce scenarios.

- Defense Advanced Research Projects Agency, for work with the Electronic CAD to CAM Exchange (ECCE) project.

- GenRad, for implementation and testing of GENCAM.

- Georgia Institute of Technology, as a testbed for for technologies and standards developed through this project.

- Hewlett Packard, for implementation and testing of GENCAM.

- Institute for Interconnecting and Packaging Electronics Circuits (IPC), for development and testing of GENCAM as a design transfer solution.

- National Electronics Manufacturing Initiative, for work with the Factory Information Systems working group to identify technology roadmaps.

- ORCAD, for implementation and testing of GENCAM.

- RosettaNet, for development of relevant standard interfaces and evaluation mechanisms.

- Solectron, for implementation and testing of GENCAM.

- State University of New York at Binghamton, for investigation into the electronics supply chain.

- Surface Mount Equipment Manufacturers Association, for development of the Standard Recipe File Format as a means for transferring information to board assembly equipment.

- Veo Systems, for development of electronic commerce infrastructure. 


\section{IS7: Framework}

Principal Investigator: Neil Christopher

Telephone: (301) 975 - 3888

E-mail: neil.christopher@nist.gov

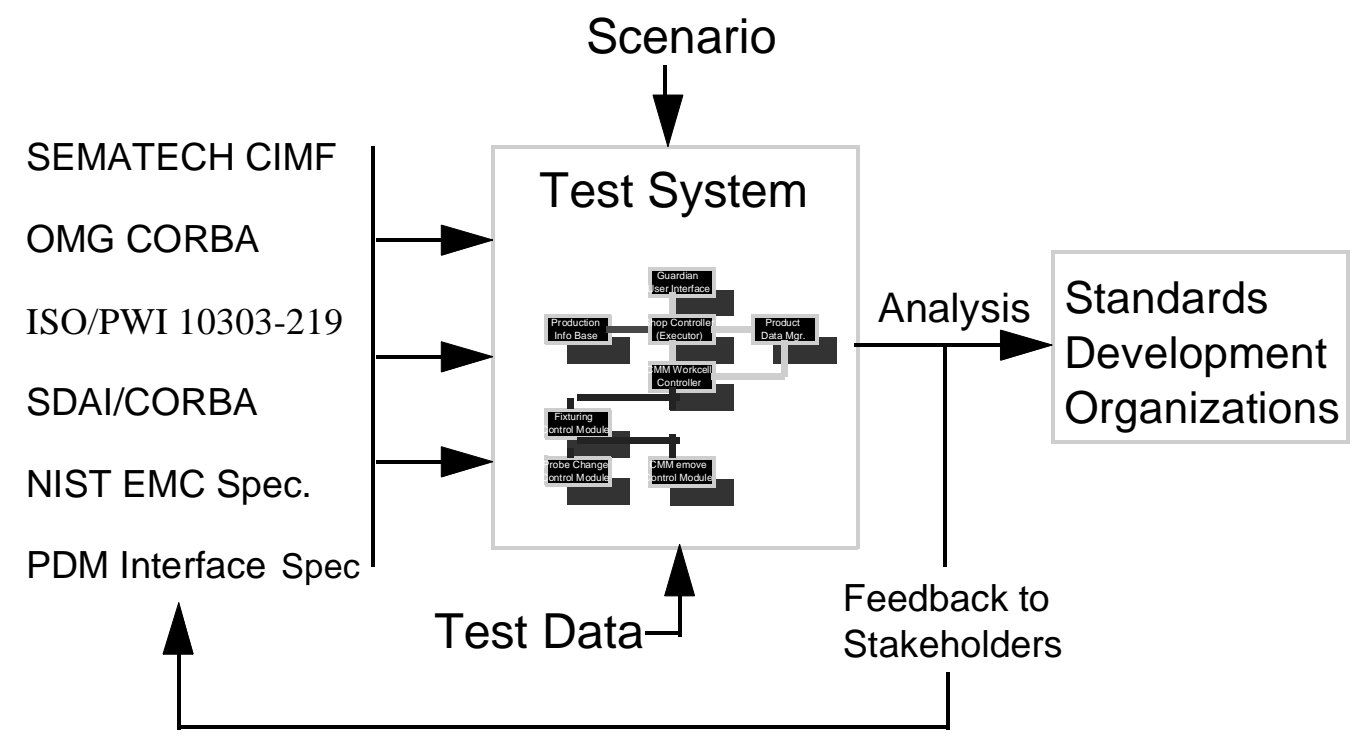

Framework Test System

The objective of this project is to accelerate the establishment and adoption of standards for distributed manufacturing systems through the implementation, testing, and analysis of emerging, open-industry specifications. In particular, this project addresses standards for the representation of information used or generated by manufacturing execution systems, enterprise resource planning systems, and shop floor control systems. The project addresses standards for the definition of interfaces to the software components that comprise these systems and the mechanisms for communication among components of these systems. The project also addresses standards for interfaces to systems that manage these types of information, such as product data managers and production information-bases. The project accomplishes its objective through validation testing of emerging, pre-standard, industry-specified, distributed manufacturing system technologies. The validation process consists of identifying specifications to test, analyzing the specifications, developing a test scenario, designing and implementing a test system and tools, feeding the results back to the industry sponsors, and feeding the results forward into the standards process. Pre-standard specifications to be evaluated must have an initial core of industry support, they must be generally non-proprietary, and they must contain elements that are suitable for standardization. These specifications are then implemented in NIST's laboratory environment and tested with production test data against a manufacturing scenario that operates physical and simulated manufacturing devices. The results of the implementation and testing form the basis for documented reviews of the specifications. These reviews address the internal consistency of each specification as well as the technical relationships among the specifications. These reviews are used as input to ongoing development within various consortia and they are used in the formal consensus building process within standards organizations. 


\section{Significant FY98/97 Accomplishments}

- Provided key technical contributions to the Object Management Group Manufacturing Domain Taskforce (MfgDTF) Product Data Management (PDM) Enablers specification.

- Provided technical contributions to the evolving Object Management Group MfgDTF standardization efforts for manufacturing execution systems, enterprise resource planning, and release for production.

- Established a formal liaison between the Object Management Group MfgDTF and the International Organization for Standardization Subcommittee on Industrial Data (ISO TC184/SC4).

- Participated in the development of a new preliminary work item (PWI) for inspection information in the Standard for Exchange of Product model (STEP - ISO 10303).

- Conducted testing on the Honeywell Advanced Process Control framework implementation in NIST's National Advanced Manufacturing Testbed.

- Completed testing of the capability of software based on Common Object Request Broker Architecture (CORBA) implementations to satisfy real-time control requirements.

- Publicly released the Manufacturer's CORBA Interface Testing Toolkit (MCITT) software.

Collaborations

- Advanced Micro Devices, for validation of the Advanced Process Control framework.

- Honeywell, for validation of the Advanced Process Control framework.

- Intelligent Automation Inc., for investigation of agent-based systems.

- Industrial Technology Institute, for development of CORBA-based interfaces.

- National Center for Manufacturing Sciences (NCMS), for development of product data management system interfaces.

- NIIIP (National Industrial Information Infrastructure Protocols), for analysis of manufacturing integration architectural approaches.

- SEMATECH, for investigation of integration methodologies and the computer-integrated manufacturing framework (CIMF).

- Software Engineering Institute, for investigation of real-time software issues.

- Technologies Enabling Agile Manufacturing (TEAM), for analysis of integration solutions.

- University of Cincinnati, for investigation of integration methodologies. 


\section{IS8: Operator Interfaces for Virtual and Distributed Manufacturing}

Principal Investigator: Ernie Kent

Telephone: (301) 975 - 3460

E-mail: ernest.kent@nist.gov

The objective of this project is to address human interface issues for development, planning, management, monitoring, and control of remote, distributed, or simulated manufacturing systems and their component activities. One approach being pursued addresses these issues in a laboratory setting using the Immersadesk virtual reality interface and other real-time graphics interfaces. A parallel approach has focused on the development of real-time, interactive, Internet-based, multi-user interfaces into manufacturing databases to support cooperative, remote access. A multi-user, realtime, interactive, shared-environment has been established that can be reached from anywhere on the Internet with PC-based equipment and standard phone lines. The general problem is to collect and present the relevant information, at the appropriate level of detail, and in the most efficient possible format, to a wide variety of remote users, operators, consultants, and decision-makers, and to allow them to singly or interactively view simulations, manipulate remote databases, examine remote situations, and cooperatively control remote environments.

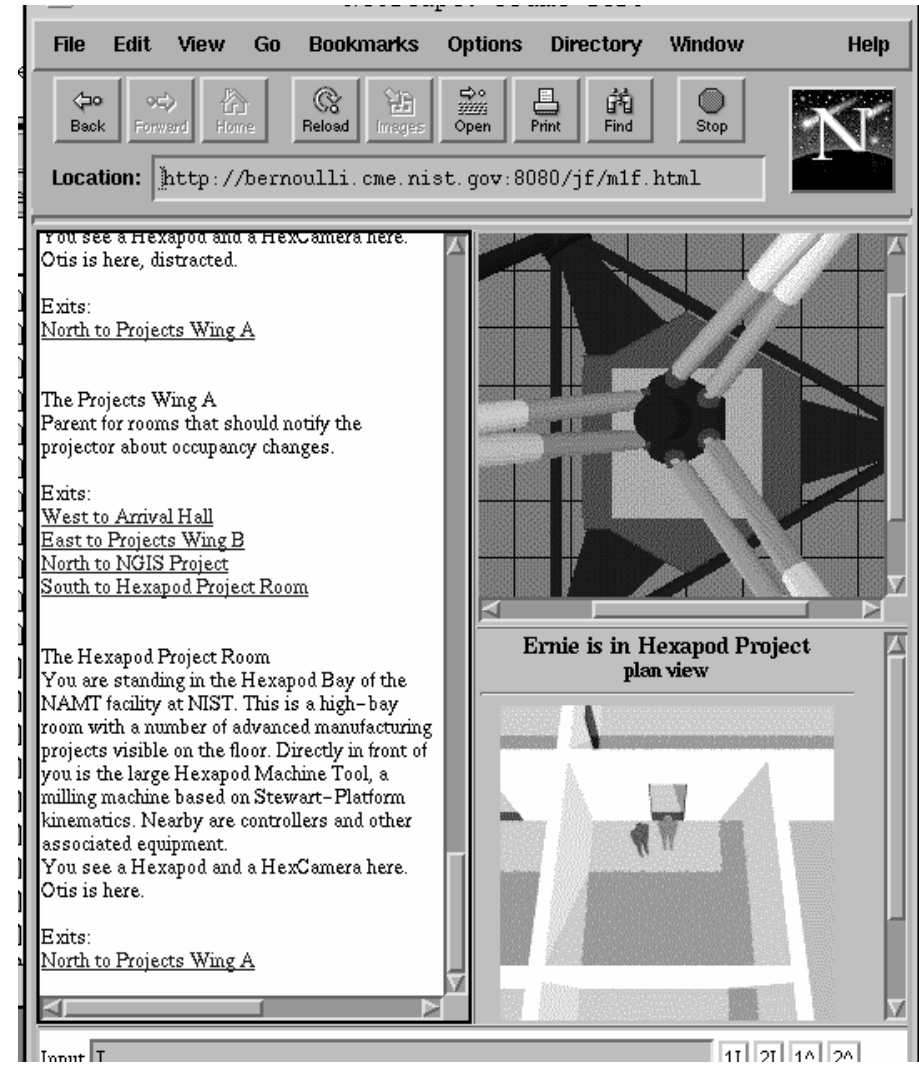

Prototype Web Interface for Hexapod Machine Tool

\section{Significant FY98/97 Accomplishments}

- Completed development of system for interfacing multiple, simultaneous, remote users to one another, to local operators, and to controlled systems using coordinated graphics and bidirectional, text-based interactions over the Internet. Demonstrated systems's functionality in the context of simulated control of an octahedral hexapod milling machine tool ("the hexapod").

- Demonstrated immersive display capabilities for hexapod workspace visualization and for observing calibration errors in laser range data.

\section{Collaborations}

- Clearwater Technical Services, for development of web-projector technology.

- Deneb Robotics, for technology transfer of Immersadesk interface software into their products.

- University of Illinois, to enhance Immersadesk capabilities. 


\section{IS9: Process Specification Language}

Principal Investigator: Craig Schlenoff

Telephone: (301) 975 - 6536

E-mail: craig.schlenoff@nist.gov

The objective of this project is to develop a process representation that is common to all manufacturing applications, generic enough to be decoupled from any given application, and robust enough to be able to represent process information for any given application. This representation, the Process Specification Language (PSL), will facilitate the automated exchange of process information

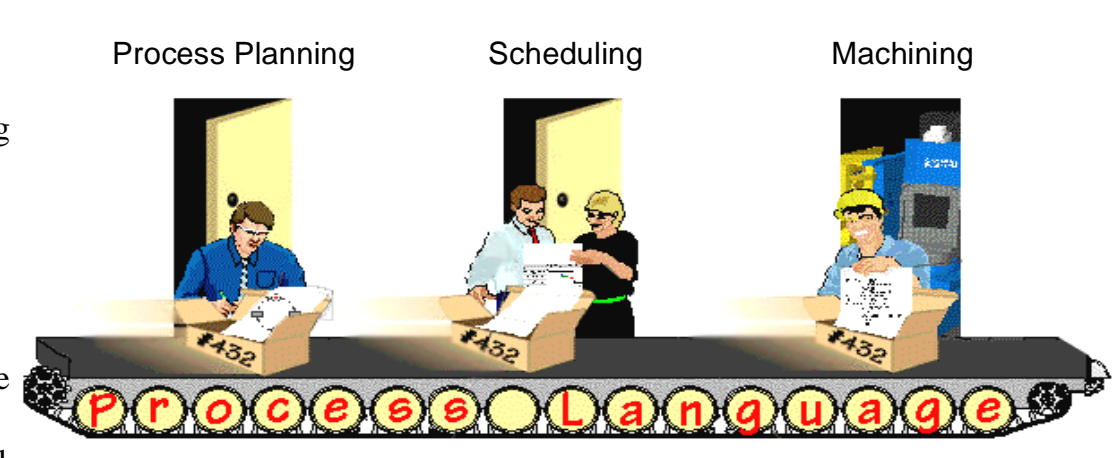

PSL-enabled information exchange among the many process-related applications found in the manufacturing environment. In the last decade, there has been an increase in the number and types of software applications that attempt to capture the essence of process. These range from tools that simply portray processes graphically to tools that enable simulation, analysis, and/or control of processes. As more of these automated applications are implemented and integrated, there must be a robust, standard, formal method for representing processes to allow for the exchange of process information. Key challenges in defining this neutral process representation include defining a common understanding of the meanings of terms (the semantics) describing process and developing multiple syntactic interpretations of these semantic descriptions to enable a mapping to various legacy applications. Several related efforts are underway to address these needs, including the Process Interchange Format (PIF) project, a DARPA-funded, informal consortium focusing on business processes. NIST is welcomed into this community as an organization that can coordinate efforts and offer expertise in manufacturing processes, in data exchange standards, and in standards development. This project is designed specifically to promote outreach and consensus through activities such as electronic discussion lists, active industry review and feedback, and on-line project status over the Internet. Already completed under this project are an indepth identification of requirements for specifying process, an analysis of existing process representations, definition of an initial core PSL, and identification and support of a community of researchers from academia and industry.

\section{Significant FY98/97 Accomplishments}

- Completed development of an initial, limited version of the Process Specification Language (PSL), which is available on the project web page (see http://ww.nist.gov/psl/).

- Conducted a "Process Information Technology" workshop in March 1998, bringing together researchers in the process specification field for the purposes of collectively addressing research issues in the field of process specification. One significant result of the workshop was to solidify the involvement of software vendors in pilot implementations of the PSL.

- Exploited the power of the Internet as the means to involve geographically dispersed reserachers in online discussion and analysis of process representations, resulting in the identification of the means to address the project's process representation requirements.

- Convened a two-day PSL roundtable meeting in April 1997, for experts from industry and academia to discuss issues central to the development of the initial version of the PSL. 


\section{Collaborations}

- Boeing Helicopter, for work with the Natural Language Processing group to develop a PSL encoding.

- Defense Advanced Research Projects Agency, for work with the DARPA-sponsored Process Interchange Format group.

- George Washington University, for investigation of process representation requirements, semantics, and scenarios.

- Knowledge Based Systems Inc., for work on the development of manufacturing semantics and pilot implementations.

- Raytheon Electronic Systems, for validation of the PSL requirements and manufacturing scenario development.

- STEP Tools Inc., for work on syntactic representations of the PSL as well as mappings to other languages.

- University of Edinburgh, for work with the Artificial Intelligence Application Institute on the development of manufacturing scenarios.

- University of Maryland, for work with the Institute for Systems Research on language development issues and the integration of formal ontologies.

- University of Toronto, for work with the Enterprise Integration Laboratory on the development of core language semantics. 


\section{IS10: Production and Product Data Management Applications}

Principal Investigator: Charles McLean

Telephone: (301) 975 - 3511

E-mail: charles.mclean@nist.gov

This project is addressing integration problems associated with product data management, production engineering, scheduling, and simulation systems. The project is developing process models, information models, interface specifications, databases, and extensions to commercial production software that resolve or facilitate system integration. After assessing industry needs, this project has selected and installed software applications that are used to engineer a production system, perform production scheduling, and simulate production.

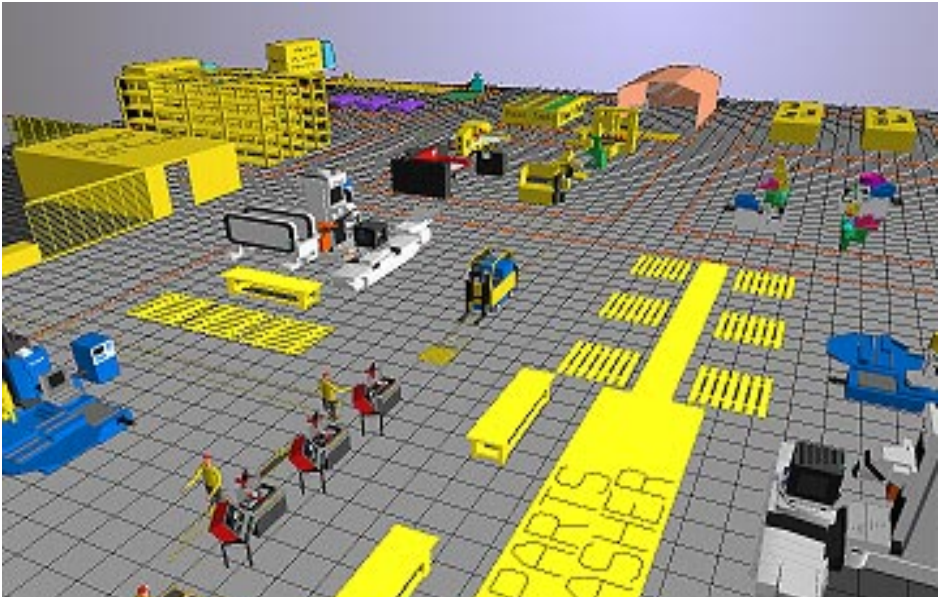

Simulated production facility

Prototype, integrated systems are being constructed from commercial products and industry-provided data. The principal elements of the technical approach are:

- identify and address critical industrial needs.

- develop solutions to integration problems for production software.

- construct prototype solutions using commercial products.

- validate results through industrial testing of system implementations.

- specify and promote needed industry standards.

- facilitate rapid commercialization of new technology.

Significant FY98/97 Accomplishments

- Developed a reactive scheduling testbed for validation of scheduling and shop floor data collection interfaces. The testbed incorporates numerous commercial software applications and employs interfaces for components developed in the Unified Modeling Language and communication among components is implemented using the Common Object Request Broker Architecture.

- Developed a supply chain simulation testbed modeling a two-level supply chain for the manufacture and distribution of personal computers. The simulation incorporates aspects of production planning, bill-of-material explosion, and master production scheduling.

- Developed a demonstration interface between assembly planning systems and a simulation of a miter saw production line.

- Provided key technical contributions to the development of the Object Management Group's Manufacturing Domain Taskforce specification for product data management interfaces.

- Submitted the SIMA Architecture Activity Models [16] to the Object Management Group's Manufacturing Domain Taskforce where it was accepted as the base roadmap document for interface standards development. 


\section{Collaborations}

- AMP, Inc., for integration of scheduling and shop floor data collection.

- Arizona State University, for development of a production systems engineering decision model.

- AutoSimulation Inc., for integration of scheduling and simulation applications with upstream and downstream applications.

- B. F. Goodrich Corp., for integration of scheduling and simulation applications with shop floor data collection and supply chain models.

- Black and Decker, to provide test parts and manufacturing data.

- Deneb Robotics, for integration of simulation applications with upstream and downstream applications.

- DLoG REMEX Inc., for integration of shop floor data collection software with upstream and downstream applications.

- Eindhoven University of Technology, for development of information models for interfaces to scheduling systems.

- Institut Francais de Mecanique Avancee, for development of infrastructure for distributed simulations.

- Intelligent Manufacturing Systems MISSION Project, for work with this international consortium on development of neutral interfaces for simulation software.

- Michigan Technological University, for development of interfaces between assembly process specification and simulation.

- Musahi University, for development of object-oriented simulation modeling and business process models for supply chain management.

- National Center for Manufacturing Sciences, for work with the Rapid Response Manufacturing (RRM) consortium on definition of product data management and manufacturing application interfaces.

- Ohio University, for engineering tool integration, simulation, and other system interfaces.

- Orca Computers Inc., for integration of simulation applications with upstream and downstream applications.

- Pennsylvania State University, for development of a routing specification interface for both scheduling and simulation.

- Politechno di Milano, for development of generic simulation objects for discrete event simulations.

- Pritsker Corporation, for integration of scheduling and simulation applications with upstream and downstream applications.

- SEMATECH, for definition of product data management and manufacturing application interfaces.

- Systems Modeling Corp., for integration of scheduling and simulation applications with upstream and downstream applications.

- University of Illinois, for development of interfaces for production systems engineering applications.

- University of Maryland, for development of information requirements and models for performance metrics for manufacturing system design.

- Universite de Nancy, for development of interfaces among scheduling, simulation, and shop floor data collection.

- Virginia Polytechnic Institute, for development of interfaces for production systems engineering applications.

- Wonderware Inc., for integrayion of shop floor data collection applications with upstream and downstream applications. 


\section{IS11: Reference Model Architecture}

Principal Investigator: Harry Scott

Telephone: (301) 975 - 3437

E-mail: harry.scott@nist.gov

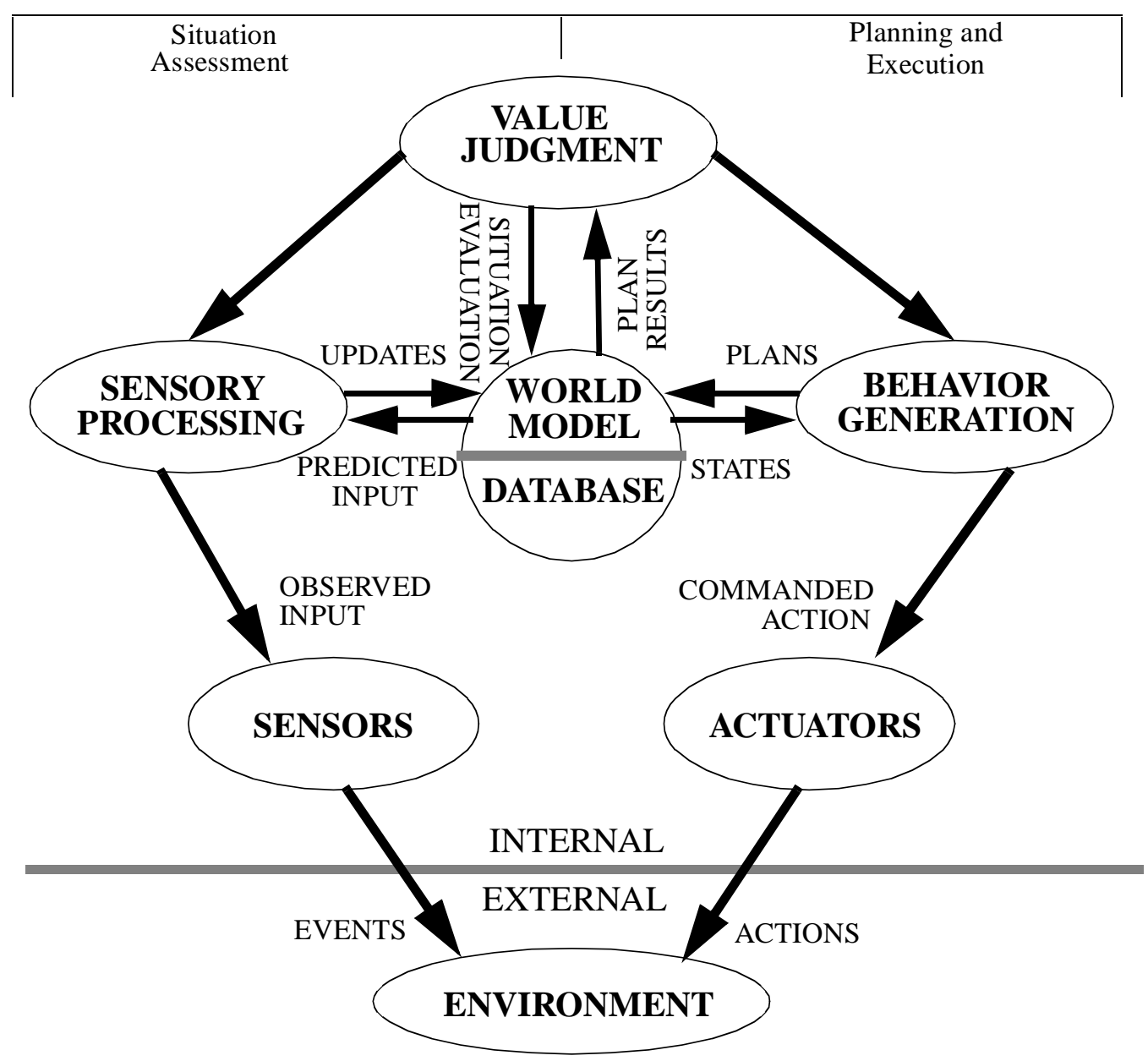

Abstract model of the architecture

The objectives of this project are to develop a detailed reference model architecture for intelligent control of manufacturing processes, and to demonstrate, validate, and evaluate the NIST Reference Model Architecture through analysis and performance measurements of a simulated and prototype implementation. The approach includes leveraging the work of other programs, such as the NIST Enhanced Machine Controller, in developing interface specifications among the architectural components, and working with industry in developing tools to support development of Reference Model Architecture-based system implementations. The goals of this work are to provide U.S. industry with state-of-the-art manufacturing architectures and models, foster the development and implementation of advanced manufacturing systems, and anticipate and address the needs of the U.S. manufacturing industry for the next generation of advanced systems and standards. 


\section{Significant FY98/97 Accomplishments}

- Completed implementation of the core functionality required for the generic control shell. Numerous improvements have been incorporated in this portion of the architecture implementation including modularization of the code structure to facilitate integration with other modules, performance measurement capabilities, and additional interfaces for planning and execution.

- Developed a testbed implementation for a coordinate measuring machine inspection workstation in which motion control and machine vision are integrated and in which features extracted from an image captured by the vision system are used to compute the actual location and orientation of the part.

- Demonstrated feature-based, inspection highlighting multi-level planning, generation of plans from feature representations, generation of coordinate measuring machine and machine tool control programs, and modularization of the architecture.

- Completed an initial version of a finite-state-machine package for the Open Modular Architecture Controller (OMAC) interface testbed.

- Hosted a meeting of the OMAC workgroup, including participation from General Motors and Boeing, in November 1997 that led to the finalization of the OMAC interface specifications.

- Participated in the formation of the Open Modular Architecture Controller Users Group in February 1997. Members include end users, integrators, and technology providers.

Collaborations

- Advanced Technology and Research Corp., for development of real-time control system software and supporting tools.

- Catholic University, for development of inspection-related software.

- Department of Energy, for work with the Technologies Enabling Agile Manufacturing (TEAM) Consortium on the development of message interfaces as part of the Intelligent Closed Loop Processing effort and for development of an enhanced machine controller (EMC).

- Enhanced Machine Controller Consortium, for development of software and hardware environments enabling implementation of Reference Model Architecture concepts.

- Drexel University, for development of experimental planning and learning components.

- National Center for Manufacturing Sciences (NCMS), for development of the Next Generation Inspection System control system.

- Open Modular Architecture Controller (OMAC) Users Group, for development of interface specifications for machine controllers.

- Real-time Innovations Inc., for investigation of control system design tools and technology transfer of architecture concepts.

- University of Illinois, for development of real-time scheduling capabilities in discrete-event systems.

- University of Maryland, for investigation of computational intelligence methodologies for learning systems and development of planner/learning functions. 


\section{IS12: STEP Conformance and Interoperability Testing}

Principal Investigator: Simon Frechette

Telephone: (301) 975 - 3335

E-mail: simon.frechette@nist.gov

This project is providing the means by which vendors' software products will be measured for conformance to the ISO 10303 (informally known as the STandard for the Exchange of Product model data, or "STEP") [12], and is promoting industry consensus on STEP implementation by identifying requirements for interoperable systems through participation in industry pilots. The project continues development of software tools for vendors to use during their product development process. With these tools, vendors gain confidence that their products can pass testing, can improve the quality of their products and reduce the costs of software testing, and gain in the expanded market that user confidence in testing brings. In

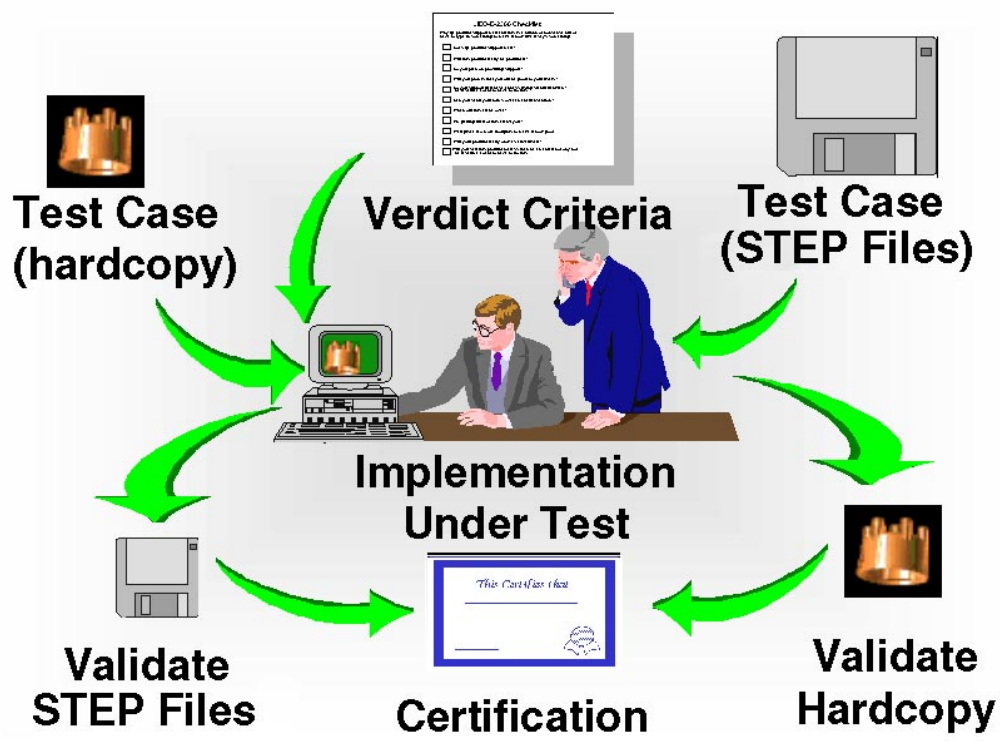

Conformance testing process addition, the project is participating in the formation of an industry-led certification authority for STEP implementations and is helping to ensure that U.S. certification procedures are compatible with foreign certification practices. Finally, through participation in industry pilots of STEP implementation, the project is helping to identify the data-exchange metrics, practices, and guidelines that will lead to improved interoperability between STEP implementations.

\section{Significant FY98/97 Accomplishments}

- Completed a revised release of the Expresso software toolkit ${ }^{1}$ which is used for validating STEP information models and the data corresponding to those models.

- Completed testing trials for a revised version of the STEP conformance testing tools with the participation of four major computer-aided design system vendors.

- Provided significant contributions to STEP testing standards, including abstract test suites as well as a technical corrigendum for ISO 10303-203 [17] (Configuration controlled 3-dimensional design).

- Participated in the formation of a U.S. certification control board for vendor implementations of STEP. The board includes representatives from the STEP user community and from the STEP implementer community as well as representation of a commercial test laboratory that will be conducting the actual certification tests.

- Developed evaluation metrics for data exchange trials conducted under the auspices of the AutoSTEP implementation pilot project and performed analyses of exchange results to isolate sources of errors.

1. For more information about Expresso see Program Products Newly Available in FY97-98 (p. 84 ). 


\section{Collaborations}

- Automotive Industry Action Group, for work on the evaluation of STEP capabilities in production environments.

- Boeing, for development of conformance testing and vendor certification requirements.

- Industrial Technology Institute, for development of STEP test systems and test methods.

- National Industrial Information Infrastructure Protocols, for investigation of protocols facilitating the establishment of virtual enterprises.

- PDES Inc., for validation of conformance testing tools through pilot implementation projects and for investigation of solutions to STEP interoperability issues.

- U.S. Army Tank Automotive Command, for investigation of STEP implementations for the defense supply chain.

- Wayne State University, for investigation of business issues related to STEP adoption. 


\section{Project Accomplishments}

\section{IS13: STEP for the Process Plant Industries}

Principal Investigator: Mark Palmer

Telephone: (301) 975 - 5858

E-mail: mark.palmer@nist.gov

This project is working with industry to develop, test, and demonstrate the ISO 10303 (informally known as the STandard for the Exchange of Product model data, or "STEP”) [12] application protocols (APs) needed for exchanging and sharing information during the design, construction, operations, and maintenance of process plants. The objectives of this project are:

- analyze the information exchange problems and needs of the process plant industries.

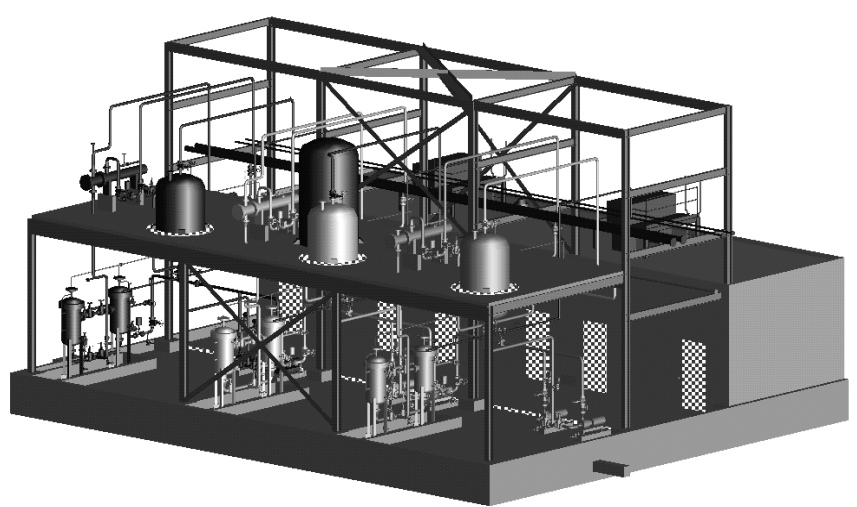

Process plant model

- define a strategy for the collaborative development of the STEP application protocols (APs) that meet the industries' requirements.

- work with industry to develop and validate the highest priority APs.

- demonstrate prototypes and support the industrial implementation of these APs as international standards.

Significant FY98/97 Accomplishments

- Completed the draft international standard version of the Plant Spatial Configuration application protocol specification (ISO 10303-227) [18].

- Completed the committe draft version of the Process Engineering Data application protocol specification (ISO 10303-231) [19].

- Provided significant technical contributions to the review of the committe draft ballot on the Functional Data and Schematic Representation for Process Plant application protocol specification (ISO 10303-221) [20].

- Completed an initial version of the Process Industry Executive for achieving Business Advantage using Standards for data Exchange (PIEBASE) Industry Activity Model; the model has since been adopted by mutiple ISO standards development projects.

- Established an implementers forum enabling users and developers of ISO 10303-227 to resolve ambiguities in the specifications in the context of industry trial implementations.

Collaborations

- Bechtel, for development, testing, and deployment of ISO 10303-227 as well as on PIEBASE efforts.

- Black \& Veatch, for development of ISO 10303-227 and on an industry roadmap for information exchange standards for the process and construction industries.

- DuPont, for development, testing, and deployment of ISO 10303-227 and ISO 10303-231 as well as on PIEBASE efforts.

- Merck, for development, testing, and deployment of ISO 10303-227 as well as on PIEBASE efforts.

- PIEBASE, for development of an industry roadmap for information exchange standards for the process and construction industries as well as the development of a common industry activity model.

- PlantSTEP Inc., for development of ISO 10303-227 and on development of test suites for that standard.

- POSC (Petrotechnical Open Software Corporation), to identify industry requirements for standards to support data sharing over the lifecycle of process plants.

- Process Data eXchange Institute of AIChE (pdXi), for development of ISO 10303-231 and on development of test suites for that standard. 


\section{IS14: Virtual Environments and Visualization for Manufacturing}

Principal Investigator: Sandy Ressler

Telephone: (301) 975 - 3549

E-mail: sressler@nist.gov

The objective of this project is to create new visualization environments that improve the usability of the data available from advanced manufacturing software. By creating prototypes of various virtual manufacturing worlds we will provide human interface guidelines to improve the effectiveness of those worlds. Existing proprietary software tools are being used as mechanisms to create portable, interoperable environments using non-proprietary standard representations such as the Virtual Reality Modeling Language (VRML) (ISO 14772). Finally, the introduction of virtual humans into the factory floor will revitalize the practice of ergonomic and human motiontime studies, a necessary factor in the design of production spaces.

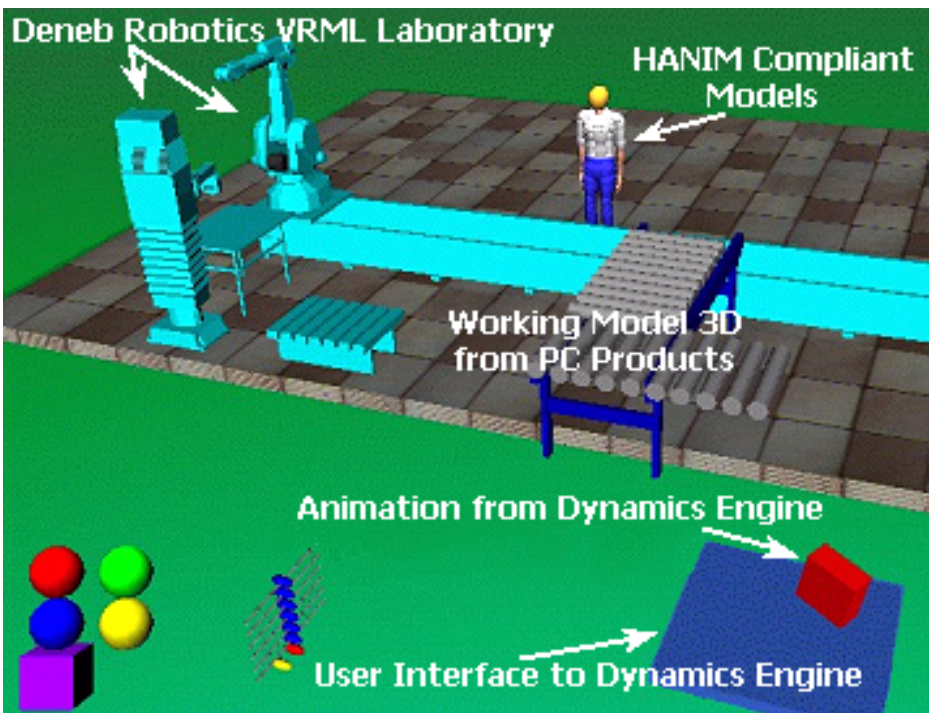

Simulation model of product assembly line

\section{Significant FY98/97 Accomplishments}

- Developed VRML translators enabling integration of multiple software vendors' virtual environment/simulation systems into a single virtual world. Knowledge Revolution has incorporated the NIST-developed translation capabilites into their commercial "Working Model 3D" product.

- Provided Internet access to a collection of children's anthropometric data originally developed by the Consumer Product Safety Commission in the 1970's. Through collaboration with Transom Technologies, this data has been incorporated into Transom's commercial "Jack" human ergonomic modeling product.

- Organized and conducted a workshop on Systems Anthropometry in conjunction with the Consumer Product Safety Commission in April 1997.

\section{$\underline{\text { Collaborations }}$}

- Black and Decker, for provision of manufacturing data and scenarios.

- Consumer Product Safety Commission, for investigation of human anthropometry issues.

- Deneb Robotics, for investigation of the use of VRML in conjunction with their software.

- Knowledge Revolution, for investigation of the use of VRML in conjunction with their software.

- Transom Technologies, for investigation of human modeling issues.

- University of Pennsylania, for investigation of human modeling issues. 


\section{Information Access Project Summaries}

\section{IA1: Analysis Tools for Assessment and Optimization of Process and Product Design}

Principal Investigator: James Filliben

Telephone: (301) 975 - 2855

E-mail: filliben@cam.nist.gov

The objective of this project is to develop an integrated computer environment that provides a design/manufacturing engineer immediate on-line access to those statistical analysis tools necessary for characterizing, modeling, monitoring, and optimizing a process or product. This is achieved by creating an engineering-friendly, integrated system with the following capabilities:

- ready access to an on-line "statistics for engineering" handbook with state-of-the-art discussion/exposition of statistical solutions for everyday engineering problems.

- an on-line translator that maps engineering problems into appropriate statistical counterparts.

- an on-line solver that identifies via its structure what the optimal statistical methodology is for a given engineering problem.

- an on-line environment that has seamless and simultaneous access to both the engineer's data and to an appropriate analysis engine so

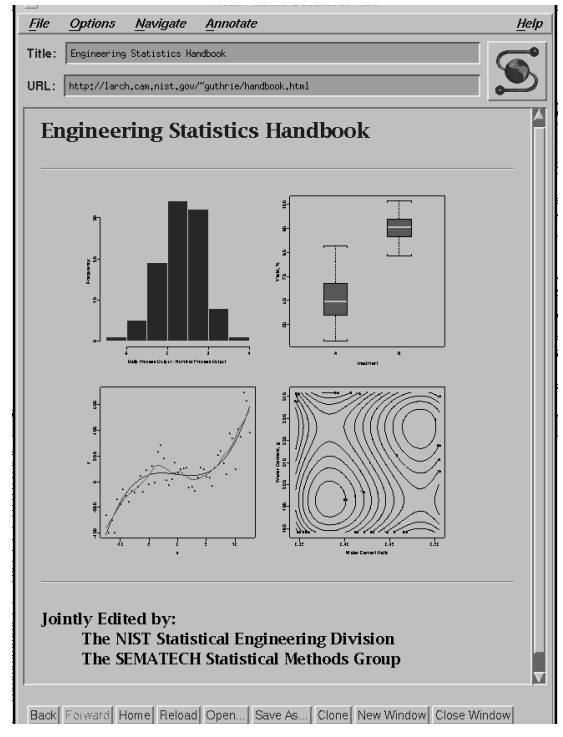

Web interface to handbook as to automatically and immediately apply the correct methodology to the engineer's data.

- an on-line interpreter that translates the output of the statistical methodology tools into conclusions that are significant and meaningful to the engineer.

\section{Significant FY98/97 Accomplishments}

- Augmented Dataplot statistical software engine for easier access from Windows and Windows NT platforms.

- Developed draft version of revised Dataplot statistical software reference manual. Tested options for transforming the manual into an Internet-accessible version.

- Implemented a prototype version of an on-line "graphics gallery" providing a resource for common graphical data analysis techniques referred to and recommended during handbook usage.

- Implemented an initial on-line resource consisting of frequently-asked-questions on Dataplot usage.

- Implemented an initial version of an on-line glossary to reduce terminology ambiguities that may arise between statistical and engineering disciplines.

- Developed and evaluated alternatives in the handbook organization, structure, and visual design.

- Implemented prototype versions of parts of selected chapters to identify issues of dynamics and navigation.

- Developed a compact navigation bar and uniform layout to apply to all handbook pages.

- Converted prototype handbook text, equation, and graphics input from multiple platform sources. Evaluated different text to hypertext markup language (HTML) processing systems. Started investigation to allow direct HTML entry via HTML template to obviate conversion problems and increase flexibility and uniformity of page appearance. 


\section{Collaborations}

- Advanced Micro Devices, to co-author the Engineering Statistics Handbook.

- Arizona State University, to co-author the Engineering Statistics Handbook.

- Motorola, to co-author the Engineering Statistics Handbook.

- SEMATECH, to co-author the Engineering Statistics Handbook.

- University of Texas, to co-author the Engineering Statistics Handbook. 


\section{IA2: Web-based Testing Service for Coordinate Measuring Machine (CMM) Software}

Principal Investigator: Neil Christopher

Telephone: (301) 975 - 3888

E-mail: neil.christopher@nist.gov

Initiated in 1998, this project is working to provide a web-accessible testing service for coordinate measuring machine (CMM) software. The web-based service will be implemented using NIST's existing Special Test Service, which is currently providing industry with assessment of the accuracy of the geometric algorithms embedded in CMMs. CMMs are used in the discrete parts industry to determine whether manufactured parts meet tolerance specifications. The webbased calibration service will give CMM users the capability of performing CMM

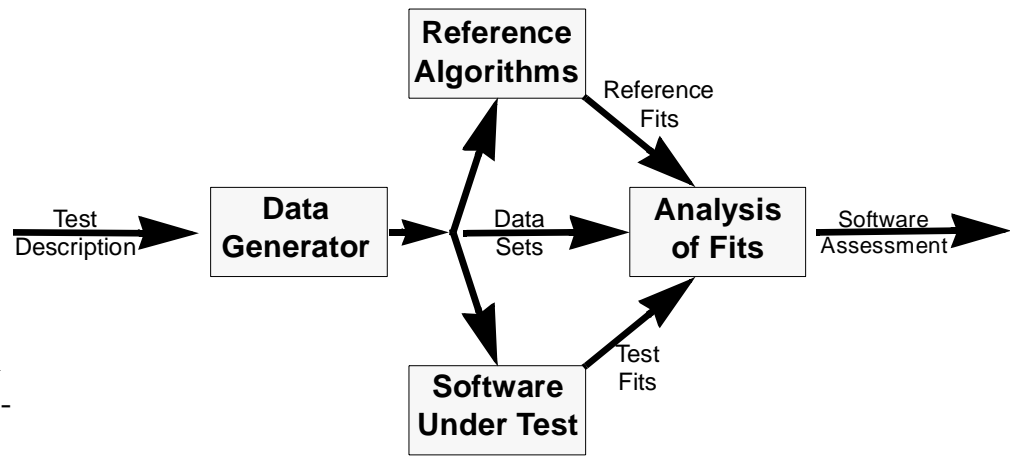

CMM software testing process software validation tests readily in house while still acquiring official results from NIST. The dimensional metrology community, users, vendors, and manufacturers of CMMs need formal mechanisms for testing and evaluating the performance of data analysis software embedded in CMMs. This service will help industry reduce inspection costs, improve procurement methods, and decrease measurement uncertainties, while providing traceability of measured results to national standards.

\section{Significant FY98/97 Accomplishments}

- Documented initial requirements for web-based testing-service capabilities, documented design specifications, and specified user interface characteristics.

- Developed initial testing-service database, demonstrating an interface to an underlying commercial database management system and an interface to a commercial mathematical analysis software application.

\section{Collaborations}

- Computer Data Systems Inc., for implementation of the web interface to the existing special test service. 


\section{$\underline{\text { Standard Reference Data Delivery and Use Projects }}$}

Project Coordinator: John Rumble

Telephone: (301) 975 - 2200

E-mail: john.rumble@nist.gov

Critical decisions in manufacturing and engineering depend on reliable data. The NIST Standard Reference Data Program (SRDP) provides numeric data, critically evaluated in data centers throughout the NIST laboratories. The thrust of this group of SIMA projects is to make that data more readily available to engineers and scientists in U.S. industry. The breadth of the NIST data program and the diverse expectations of the industrial community require that NIST provide tools to help users find the data they need. Project participants are creating ways to reuse existing structures and algorithms and generating new algorithms where necessary to deliver existing and future NIST data so

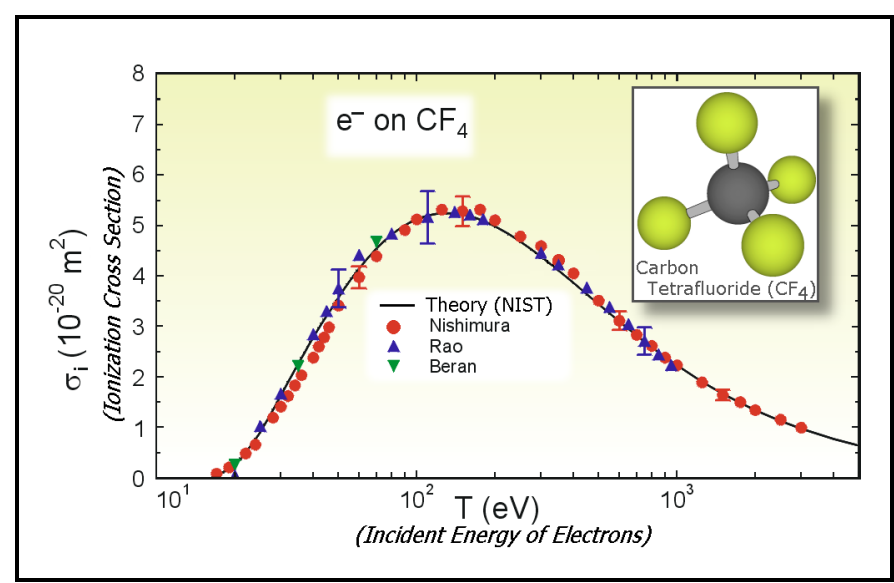

Data plot from the NIST ionization cross section database that the data are both accessible on-line to individuals and freely exchangeable among instruments. SIMA efforts are taking place in three NIST laboratories, the Chemical Science and Technology Laboratory, the Materials Science and Engineering Laboratory, and the Physics Laboratory. These SIMA efforts are coordinated and jointly supported by SRDP. Recently released or revised on-line sources of standard reference data (SRD) information are detailed in Appendix D, "Program Products Newly Available in FY97-98" on page 84.

\section{IA3: Computerized Access to Full Structural Crystallographic Data}

Principal Investigator: Vicky Lynn Karen

Telephone: (301) 975 - 6255

E-mail: vicky.karen@ nist.gov

Initiated in 1998, this project is working to make the inorganic crystal structure database readily accessible via the Internet using a modern database management system and to offer additional functionality through the development of software tools for the calculation and standardization of derived data items as well as modules for intelligent access of scientific data.

Significant FY98/97 Accomplishments

- Created initial relational database structure from existing inorganic crystal structure data files.

- Completed preliminary design for a graphical user interface based on the periodic table of the elements.

Collaborations

- Fachinformationszentrum Karlsruhe Gesellschaft für wissenshaftlich-technische Information mbH (FIZ Karlsruhe), for development of the inorganic crystal structure database.

- Max-Planck Gesellschaft zur Förderung der Wissenschaften e.V., (the Max Planck Society for the Advancement of the Sciences) for development of the inorganic crystal structure database. 


\section{IA4: Green's Function Library for Advanced Materials Applications with Web Access}

Principal Investigator: Vinod Tewary

Telephone: (303) 497 - 5753

E-mail: tewary@boulder.nist.gov

The objective of this project is to develop an Internet-accessible tool for using Green's function and boundary element methods in analysis of components made with advanced materials. With the Green's functions approach, problems in stress analysis, ultrasonics, and acoustics involving anisotropic materials can be analyzed more efficiently than with conventional approaches.

\section{Significant FY98/97 Accomplishments}

- Completed a Green's Function Library capability to calculate and visually display farfield ultrasonic data for scattering of ultrasonic waves from buried flaws in linear, isotropic, and elastic structures.

- Completed a Green's Function Library capability to calculate and display results for intact and damaged composite material models.

Collaborations

- Colorado School of Mines, for development of the library and the user interface to the library.

- Iowa State university, for development of the library in the context of specialized applications.

\section{IA5: Integration of NIST Standard Reference Data into Information Networks}

Principal Investigator: Edward Saloman

Telephone: (301) 975 - 5554

E-mail: edward.saloman@ nist.gov

The objective of this project is to make physical reference data available via the Internet (http://physics.nist.gov/data) and in so doing demonstrate a prototypical framework for making the full range of scientific and engineering information available to application systems.

\section{Significant FY98/97 Accomplishments}

- Released the NIST standard reference database for photon cross sections for use via the Internet. This database can be used to determine photon cross sections for scattering, photoelectric absorption, and pair production as well as total attenuation coefficients in any element, compound or mixture. The database provides both graphic and tabular results as well as providing users with the capability to upload a set of energies for which tabular results will be calculated. These data are used in many scientific and engineering applications as well as in medical applications.

- Revised and upgraded both the database of fundamental physical constants and the bibliographic database of fundamental physical constants. The latter database has provided citations for important theoretical and experimental publications relevant to the fundamental physical constants and related precision measurements since the mid 1980s. For both databases, new user interfaces were developed, new references were added, and the capability to "cut and paste" materials from the database was added.

- Released the database of electron-impact ionization cross sections for use via the Internet. The database provides the analytic formula and a means of calculating cross sections at given energies with results presented in both tabular and graphical forms. These data are used in the modeling of plasmas used in semiconductor processing, design of flourescent lamps, and in modeling radiation effects on materials. 


\section{Collaborations}

- Harvard-Smithsonian Center for Astrophysics, for development of the atomic spectroscopy database.

- University of Melbourne, for development of the X-ray form factor, attenuation, and scattering database.

- University of New Brunswick, for development of a database of ground state energy levels for certain small molecules.

\section{IA6: NIST Ceramics WebBook}

Principal Investigator: Ed Begley

Telephone: (301) 975 - 6118

E-mail: edwin.begley@nist.gov

The objective of this project is to make NIST ceramics-related reference databases, topical data sets, data guides and advisories, tools, and references to other resources related to advanced ceramics materials accessible via the Internet (http://www.ceramics.nist.gov/webbook/webbook.htm).

\section{Significant FY98/97 Accomplishments}

- Released the structural ceramics database for use via the Internet. Structural ceramics are used in designs of high efficiency, high temperature heat exchangers, corrosion resistant components, and electronic packaging. The database contains high temperature mechanical, thermal, and corrosion materials property data for a wide variety of boride, carbide, nitride, oxide, and oxynitride materials.

- Released the high temperature superconducting materials database for use via the internet. High temperature superconductivity remains a field of great interest to scientists and engineers. This database provides physical and materials characteristics for oxide superconductors.

\section{IA7: Online Access to NIST Chemical Reference Data}

Principal Investigator: Gary Mallard

Telephone: (301) 975 - 2564

E-mail: gary.mallard@nist.gov

The objective of this project is to make NIST chemical reference data available via the Internet (http:// webbook.nist.gov/chemistry/) and to develop the tools and mechanisms necessary to make all NIST chemical data uniformly accessible.

\section{Significant FY98/97 Accomplishments}

- Released three new versions of the NIST Chemistry WebBook in the last two years.

- Augmented capabilities for searching by chemical substructures by enabling input of industry standard file formats as well as by specification of structures through an interactive drawing applet.

- Provided new data types, including Henry's Law constants (solubility of gas in water), fundamental infrared frequencies, and high accuracy fluid properties.

- Enhanced tools for acquiring Chemical Abstract Service registry numbers from files for more rapid processing.

- Improved equation handling capabilities as well as the graphical display of equations. Developed browserindependent and operating system-independent mechanisms for display of Greek and scientific characters. 


\section{Collaborations}

- Dow Chemical, for development of prediction techniques.

- Long Island University, for evaluation of data for hydrogenation reactions.

- Monsanto Chemical Company, for evaluation of data for phosphorous compounds.

- Pacific Northwest Laboratory, for development of prediction techniques.

- University of Canterbury, for evaluation of ion cluster data.

- University of Maryland, for evaluation of data for chemical thermodynamics.

- University of Tennessee, for evaluation of data for ion thermochemistry.

\section{IA8: Standards for Exchange of Instrument Data and NIST Chemical Reference Data}

Principal Investigator: Gary Kramer

Telephone: (301) 975 - 4132

E-mail: gary.kramer@nist.gov

The objective of this project is to develop information models supporting data exchange standards in analytical chemistry for instrument-to-instrument, instrument-to-application, and application-to-application interchanges and to evaluate current industry standards for NIST reference data interchange.

Significant FY98/97 Accomplishments

- Extended the device capability dataset for laboratory instruments with the notion of system-level capabilities. Initiated prototype implementation for these instrument interfaces using a spectrophotometer as the basis for validation.

- Presented project results at several significant events, including a keynote address on laboratory automation at Eastman Chemical's Annual Analytical Technology Forum and award-winning poster presentations at the LabAutomation 1998 Conference in San Diego, CA.

- Advanced several specifications further in the ASTM standardization process, including the Laboratory Equipment Communication Interface Specification and the Analytical Data Interchange Standard.

\section{Collaborations}

- Fachhochschule Wiesbaden, for development of instrument control interface models.

- Hypertek Inc., for development of software for control of laboratory instruments.

- Information Management Resources, for development of databases supporting data sharing among instruments.

- Los Alamos National Laboratory, for implementation and validation of instrument control interface specifications.

\section{IA9: Web-Based Bioinformatics Databases}

Principal Investigator: Michael Gilson

Telephone: (301) 738 - 6217

E-mail: michael.gilson@ nist.gov

Principal Investigator: Gary Gilliland

Telephone: (301) 975 - 2629

E-mail: gary.gilliland@ nist.gov

The objective of this project is to provide access to two databases of importance to biotechnology and that contain evaluated data on the properties, structures, and interactions of biological macromolecules. One database focuses on data characterizing the recognition by one molecule of a suitable reaction site on another; this database will also feature an online contribution facility. The second database is the Protein Data Bank, an international archive. This second database will also will be coupled with internet-accessible data evaluation software. 


\section{Significant FY98/97 Accomplishments}

- Formed the Research Collaboratory for Structural Bioinformatics (RCSB) as a non-profit consortium dedicated to improving the understanding of biological systems through knowledge of 3-dimensional biological macromolecular structures. Other members are Rutgers University and the University of California.

- Developed comprehensive plans for the scope, implementation, and management of the molecular recognition database were developed in conjunction with bioinformatics groups at Rutgers University and the University of California.

- Completed work to adapt the software programs MAXIT and mmCIF Input Tool to allow their use in the evaluation and conversion of protein data structures.

- Completed the evaluation and conversion of all structures in one family of proteins and initiated work on the evaluation and conversion of proteases, immunoglobins, and hemoglobins; together these represent a significant fraction of the Protein Data Bank.

- Hosted a workshop on molecular recognition issues, August 1997. The workshop helped to establish a preliminary data model, the scope of data to be included in the molecular recognition database, preliminary guidelines for the user interface to the database, and future collaborative work. Participants included representatives from pharmaceutical companies, academic institutions, and other government agencies.

\section{$\underline{\text { Collaborations }}$}

- DuPont Merck Pharmaceutical Company, for development of the molecular recognition database.

- Robert Wood Johnson Medical School, for development of the molecular recognition database.

- Rutgers University, for development of the molecular recognition database.

- University of California, for work with the San Diego Supercomputer Center on development of the molecular recognition database.

- University of Pittsburgh, for investigation of molecular recognition involving small organic molecules. 


\section{Collaboration Mechanisms Project Summaries}

\section{CM1: NIST Manufacturing Collaboratory}

Principal Investigator: Michelle Steves

Telephone: (301) 975 - 3537

E-mail: michelle.steves@ nist.gov

Principal Investigator: Amy Knutilla

Telephone: (301) 975 - 3514

E-mail: amy.knutilla@nist.gov

The objective of this project is to enable individuals and groups of manufacturing researchers to gain access to, as well as contribute to, the collective knowledge regarding advanced manufacturing research and standards in a coherent, unencumbered fashion. The project will work to address manufacturing domainspecific issues for collaboratories and collaboratory technologies. A testbed for research in collaboratory technology for manufacturing will be developed. The testbed will provide an environment to test the applicability of humancentered design when applied to manufacturing requirements. In the longer term there is the expectation that deployment of collaboration technologies in the manufacturing environment will lead to new business processes and these in turn will lead to the identification of new manufacturing software integration requirements.

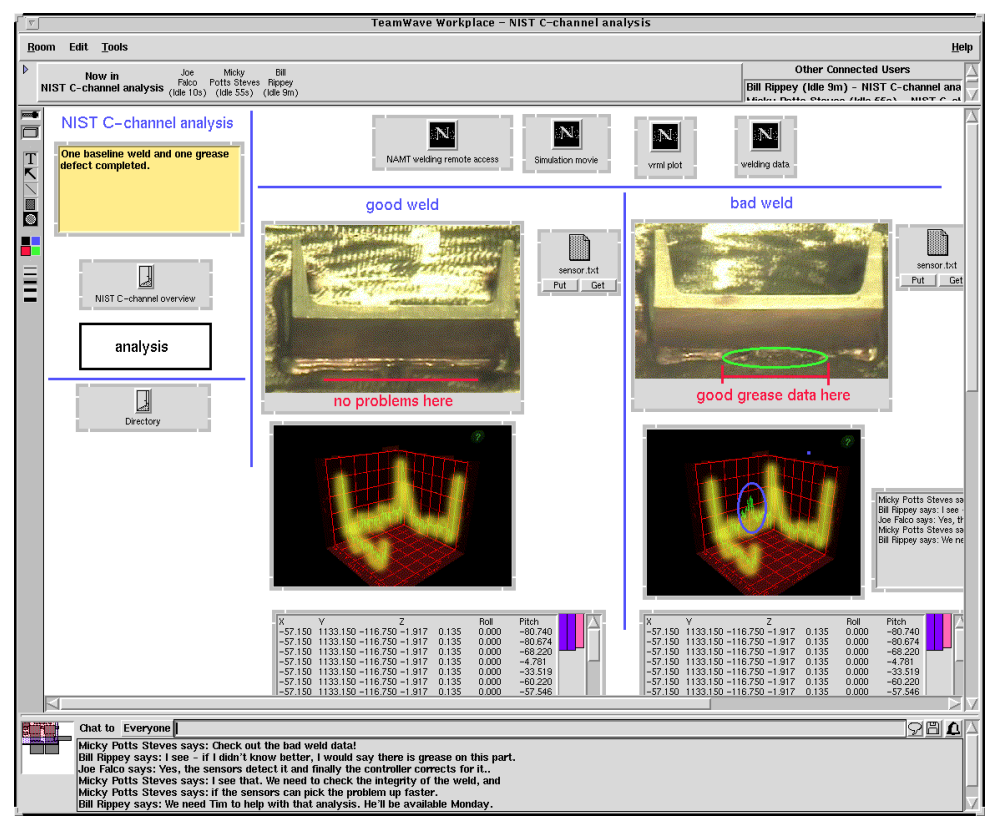

Remote welding collaboration demonstration

\section{Significant FY98/97 Accomplishments}

- Identified and analyzed initial user requirements for systems and tools to be included in the initial collaborative environment. Selected commercial off-the-shelf tools and customized them according to user needs.

- Deployed a pilot collaboratory for robotic arc welding researchers developing standards for automated robotic gas-metal arc welding. The pilot environment enables synchronous and asynchronous collaborations, exchange of mutiple diverse data formats, and remote collaborations. Participating researchers are located on the NIST Gaithersburg (Maryland) campus and the NIST Boulder (Colorado) campus as well as at industrial sites in Illinois, Michigan, and Ohio.

- Initiated investigations into how to assess the effectiveness of collaborations in the robotic arc welding pilot.

Collaborations

- General Motors Corporation, for investigation of robotic arc welding collaboratory capabilities for troubleshooting problems on the shop floor.

- Sun Microsystems, for implementation and analysis of the pilot collaboratory.

- TeamWave Software, Ltd., for implementation and assessment of collaboration systems.

- University of Michigan, for development, piloting, and analysis of collaboratories in the manufacturing domain. 


\section{CM2: Virtual National Advanced Manufacturing Testbed (VNAMT)}

Principal Investigator: Keith Stouffer

Telephone: (301) 975 - 3877

E-mail: keith.stouffer@nist.gov

Initiated in 1998, this project is working to provide an Internetaccessible version of NIST's

National Advanced

Manufacturing Testbed (NAMT) bringing the capabilities of the NAMT and results stemming from NAMT projects to interested researchers and collaborators. The multimedia VNAMT environment will provide access to live and stored video, control of cameras in NAMT project laboratories, interactive manipulation of virtual reality models of equipment, and relevant project information.

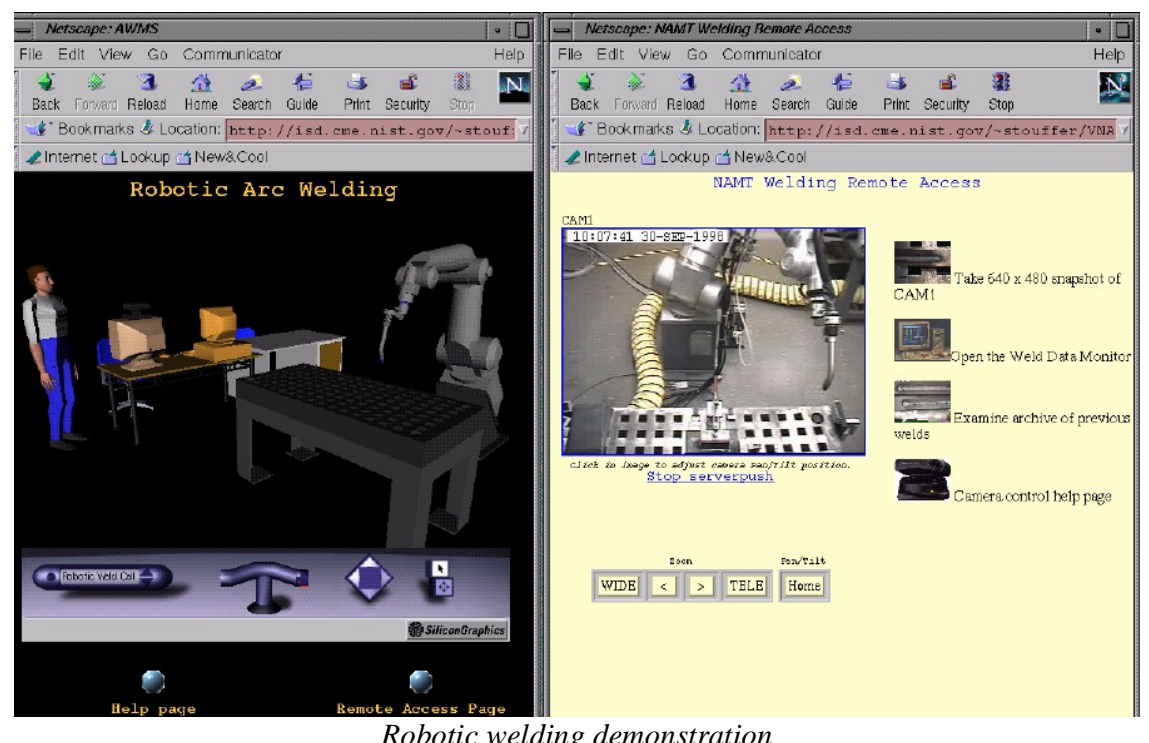

Significant FY98/97 Accomplishments

- Developed a prototype VNAMT environment illustrating capabilities to provide live video from welding experiments, client control of cameras, controller interfaces, and interactive models of NIST's octahedral hexapod machine tool.

\section{Supported Projects}

- Nanomanufacturing of Atom-Based Dimensional Standards http://www.mel.nist.gov/namt/projects/nano/nano1.htm

- Characterization, Remote Access, and Simulation of Hexapod Machines http://www.mel.nist.gov/namt/projects/hexapod/hex1.htm

- Interface Standards and Internet Technologies for Robotic Arc Welding http://www.mel.nist.gov/namt/projects/weld/weld1.htm 


\section{Conclusion}

The premise of the SIMA Program is that the multitude of software systems used in manufacturing activities do not interoperate as well as required. The SIMA Program's project leaders work with their industrial partners to identify information needs among manufacturing enterprise activities, the contexts for those needs, in order to identify the information representation issues between the software systems used in those activities, and to define mechanisms appropriate to resolving those issues. By maintaining a neutral perspective in the testing of information interfaces for engineering and manufacturing, the Program ensures that validated solutions addressing the common requirements of both users and software providers can be adopted.

\section{References}

[1] "Technical Program Description Systems Integration for Manufacturing," Bloom, H., NISTIR 5476, NIST, Gaithersburg, MD, July 1994.

[2] "Systems Integration for Manufacturing Applications Technical Program Plan,” Fowler, J., NISTIR 5986, NIST, Gaithersburg, MD, March 1997.

[3] "Systems Integration for Manufacturing Applications Program 1995 Annual Report," Fowler, J., Luce, M., NISTIR 5839, Gaithersburg, MD, May 1996.

[4] "Systems Integration for Manufacturing Applications Program 1996 Annual Report," Fowler, J., NISTIR 6026, Gaithersburg, MD, May 1997.

[5] "High Performance Computing and Communications: Toward a National Information Infrastructure," Report by the Committee on Physical, Mathematical, and Engineering Sciences, Federal Coordinating Council for Science, Engineering, and Technology, Office of Science and Technology Policy, published by the National Coordination Office for HPCC, 1994.

[6] "Information Infrastructure Technology and Applications," Report of the IITA Task Group, High Performance Computing, Communications and Information Technology Subcommittee, Federal Coordinating Council for Science, Engineering, and Technology, Office of Science and Technology Policy, published by the National Coordination Office for HPCC, February 1994.

[7] "HPCC FY95 Implementation Plan," Office of Science and Technology Policy, published by the National Coordination Office for HPCC, April 1994.

[8] "High Performance Computing and Communications: Advancing the Frontiers of Information Technology," Report by the Committee on Computing, Information, and Communications, National Science and Technology Council, published by the National Coordination Office for Computing, Information, and Communications, 1996.

[9] "Networked Computing for the 21st Century," Report by the Subcommittee on Computing, Information, and Communications, Committee on Technology, National Science and Technology Council, published by the National Coordination Office for Computing, Information, and Communications, 1998.

[10] "Initial Manufacturing Exchange Specification (IMES) Concept Document For Manufacturing Systems Integration,” Kemmerer, S., Fowler, J., ed., NISTIR 5978, NIST, Gaithersburg, MD, February 1997.

[11] "Interoperability Cost Analysis of the U.S. Automotive Supply Chain," 99-1 Planning Report, Prepared by the Research Triangle Instutute for the National Institute of Standards and Technology, March, 1999.

[12] ISO 10303-1:1994, "Industrial automation systems and integration - Product data representation and exchange - Part 1: Overview and fundamental principles," International Organization for Standardization, Geneva, Switzerland. 


\section{References}

[13] ISO 8879:1986, "Information processing -- Text and office systems -- Standard Generalized Markup Language (SGML), International Organization for Standardization, Geneva, Switzerland.

[14] ISO/IEC/DIS 10303-210 "Industrial automation systems and integration -- Product data representation and exchange -- Part 210: Electronic assembly, interconnect and packaging design,” International Organization for Standardization, Geneva, Switzerland.

[15] ISO/DIS 10303-213 "Industrial automation systems and integration -- Product data representation and exchange -- Part 213: Application protocol: Numerical control process plans for machined parts," International Organization for Standardization, Geneva, Switzerland.

[16] "SIMA Reference Architecture Part I: Activity Models," NISTIR 5939, National Institute of Standards and Technology, Gaithersburg, MD, 1997.

[17] ISO 10303-203:1994, "Industrial automation systems and integration -- Product data representation and exchange -- Part 203: Application protocol: Configuration controlled design,” International Organization for Standardization, Geneva, Switzerland.

[18] ISO/DIS 10303-227 "Industrial automation systems and integration -- Product data representation and exchange -- Part 227: Plant spatial configuration,” International Organization for Standardization, Geneva, Switzerland.

[19] ISO/CD 10303-231 "Industrial automation systems and integration -- Product data representation and exchange -- Part 231: Process engineering data: Process design and process specification of major equipment," International Organization for Standardization, Geneva, Switzerland.

[20] ISO/CD 10303-221 "Industrial automation systems and integration -- Product data representation and exchange -- Part 221: Functional data and their schematic representation for process plants," International Organization for Standardization, Geneva, Switzerland. 


\section{Appendix A: Program Organization}

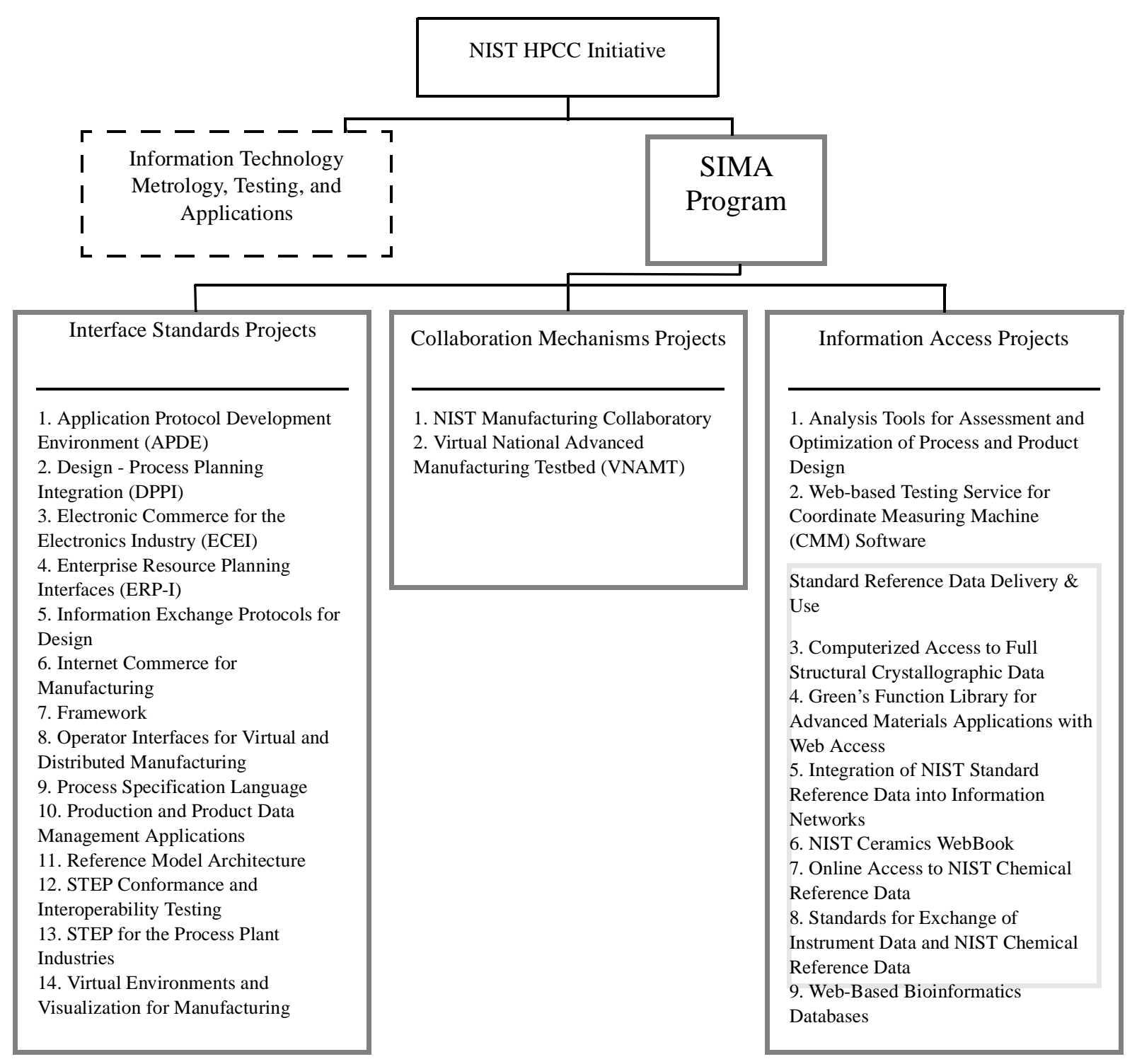

\section{Figure 4. Organization of NIST's CIC Efforts}

The SIMA Program was one of two CIC initiative efforts underway at NIST in FY97-98 (see Figure 4). The SIMA Program is directed by a manager in the Manufacturing Systems Integration Division (MSID) of NIST's Manufacturing Engineering Laboratory (MEL). Individual SIMA projects are led by NIST research staff. The projects are organized into the technology areas briefly described below. 


\section{Program Technology Areas}

To align the resources of the program with the needs defined by industry, the SIMA Program organizes projects into one of three program areas: (1) Interface Standards, (2) Information Access, and (3) Collaboration Mechanisms. Activities within each area satisfy a unique NIST role in support of CIC goals and address the major technology and standards issues outlined in the IITA program report [6]. The focus of these technology areas are as follows.

\section{Interface Standards (IS)}

These SIMA projects continue work leading to the definition and creation of standards facilitating the exchange of manufacturing data within and across all levels of the product realization process. Objectives include the establishment of:

- rigorous methods for defining and testing interoperability solutions.

- standards specifying information to be exchanged as well as the interface mechanisms necessary to do so.

- tests validating potential standards solutions and implementations.

\section{Information Access (IA)}

SIMA-supported efforts in this area are providing greatly broadened access to large amounts of authoritative scientific engineering data in NIST databases by initiating effective Internet access to those databases through userfriendly interfaces and sophisticated search techniques.

\section{Collaboration Mechanisms (CM)}

By supporting the establishment and evolution of computer-supported collaboration mechanisms for NIST researchers to work with each other and with external partners, the SIMA program aims to:

- improve the effectiveness of the researchers' work.

- evaluate and, where benefical, adapt and refine collaborative technologies.

- identify and address interaction issues resulting from remote collaborations.

\section{Participating NIST Organizational Units}

All of NIST's intramural, technical organizational units participate in the SIMA Program. The following descriptions briefly summarize the mission of each participating NIST organization ${ }^{1}$.

\section{Building and Fire Research Laboratory (BFRL)}

BFRL works to enhance the competitiveness of U.S. industry and public safety through performance prediction and measurement technologies and technical advances that improve the lifecycle quality of constructed facilities.

\section{Chemical Science and Technology Laboratory (CSTL)}

As the Nation's Reference Laboratory, CSTL performs cutting edge research in measurement science. The Laboratory develops and maintains measurement methods, standards, and reference data; and develops models for chemical, biochemical, and physical properties and processes.

1. More information about NIST Laboratories can be found at http://www.nist.gov/labs2.html. 
Information Technology Laboratory (ITL)

ITL develops, demonstrates, and supplies high quality information technology, metrology, and standards that enable U.S. industry to develop usable, reliable, interoperable products. In doing so, the ITL serves as a neutral agent to accelerate acceptance and use of information technology that will promote economic competitiveness and the public good. ITL provides leadership and collaborative research to NIST programs in the areas of mathematics, statistics, and information technology use and services to enable NIST to maintain its status as a world class institution.

\section{Electronic and Electrical Engineering Laboratory (EEEL)}

EEEL promotes U.S. economic growth through improved international competitiveness, by providing measurement capability of high economic impact focused primarily on the critical needs of the U.S. electronics and electricalequipment industries.

\section{Manufacturing Engineering Laboratory (MEL)}

MEL works to improve the competitiveness of U.S. manufacturing by working with industry to develop and apply infrastructural technology, measurements, and standards for manufacturing.

\section{Material Science and Engineering Laboratory (MSEL)}

MSEL works to stimulate the more effective production and use of materials by working with materials suppliers and users to assure the development and implementation of the measurements and standards infrastructure for materials.

\section{Physics Laboratory (PL)}

PL supports U.S. industry by providing measurement services and research for electronic, optical, and radiation technology.

\section{Technology Services (TS)}

TS provides a wide variety of services and programs to help U.S. industry improve its international competitiveness. TS supplies NIST reference materials, data, and calibrations to help industry maintain production quality control. TS also provides information and assistance concerning national and international voluntary and regulatory product standards and certification systems. 


\section{Appendix B: Collaborators}

\begin{tabular}{|c|c|c|c|}
\hline \multicolumn{4}{|c|}{ Consortia, National Programs, Professional and Trade Associations } \\
\hline Name & Location & Description & $\begin{array}{l}\text { Collaborating } \\
\text { Project(s) }\end{array}$ \\
\hline $\begin{array}{l}\text { Automotive Industry Action } \\
\text { Group (AIAG) }\end{array}$ & $\begin{array}{l}\text { Southfield, } \\
\text { MI }\end{array}$ & $\begin{array}{l}\text { An automotive trade association addressing industry } \\
\text { issues in supply, manufacturing, engineering, quality, } \\
\text { and finance. The association has over } 1000 \text { member } \\
\text { companies and includes Chrysler, Ford, and General } \\
\text { Motors. }\end{array}$ & $\begin{array}{l}\text { STEP Conform- } \\
\text { ance and } \\
\text { Interoperability } \\
\text { Testing (p. 33) }\end{array}$ \\
\hline $\begin{array}{l}\text { CAD Framework Initiative, } \\
\text { Inc. }\end{array}$ & Austin, TX & $\begin{array}{l}\text { An international, not-for-profit consortium whose mis- } \\
\text { sion is to facilitate and promote the adoption of open } \\
\text { electronic design automation technologies that improve } \\
\text { designer productivity. CFI's membership includes over } \\
40 \text { companies comprised of electronic design automation } \\
\text { designers and suppliers of high performance semi-cus- } \\
\text { tom silicon in North America, Europe, and Asia. }\end{array}$ & $\begin{array}{l}\text { Electronic Com- } \\
\text { merce for the } \\
\text { Electronics } \\
\text { Industry (ECEI) } \\
\text { (p. 17) }\end{array}$ \\
\hline CommerceNet & $\begin{array}{l}\text { Palo Alto, } \\
\text { CA }\end{array}$ & $\begin{array}{l}\text { An international, not-for-profit organization meeting the } \\
\text { evolving needs of companies doing electronic com- } \\
\text { merce. }\end{array}$ & $\begin{array}{l}\text { Internet Com- } \\
\text { merce for Man- } \\
\text { ufacturing (p. } \\
\text { 22) }\end{array}$ \\
\hline $\begin{array}{l}\text { Component Information Repre- } \\
\text { sentation European Project } \\
\text { (CIREP) }\end{array}$ & $\begin{array}{l}\text { Orsay, } \\
\text { France }\end{array}$ & $\begin{array}{l}\text { An effort funded by ESPRIT to build a complete infor- } \\
\text { mation system for the electronic exchange of standard- } \\
\text { ized libraries of Component Information } \\
\text { Representations (CIR). }\end{array}$ & $\begin{array}{l}\text { Electronic Com- } \\
\text { merce for the } \\
\text { Electronics } \\
\text { Industry (ECEI) } \\
\text { (p. 17) }\end{array}$ \\
\hline $\begin{array}{l}\text { Electronics Industries Associa- } \\
\text { tion (EIA) }\end{array}$ & $\begin{array}{l}\text { Arlington, } \\
\text { VA }\end{array}$ & $\begin{array}{l}\text { A trade association representing the U.S. high technol- } \\
\text { ogy community. EIA has created a host of activities to } \\
\text { enhance the competitiveness of the American producer } \\
\text { including such valuable services as technical standards } \\
\text { development, market analysis, government relations, } \\
\text { trade shows and seminar programs. }\end{array}$ & $\begin{array}{l}\text { Electronic Com- } \\
\text { merce for the } \\
\text { Electronics } \\
\text { Industry (ECEI) } \\
\text { (p. 17) }\end{array}$ \\
\hline $\begin{array}{l}\text { Enhanced Machine Controller } \\
\text { (EMC) Consortium }\end{array}$ & $\begin{array}{l}\text { Gaithers- } \\
\text { burg, MD }\end{array}$ & $\begin{array}{l}\text { Provides initial open-architecture control system and } \\
\text { development environment hardware and software con- } \\
\text { figuration, base controller template, Java-based operator } \\
\text { tools and communications mechanism for Joint Archi- } \\
\text { tecture project implementation testbeds }\end{array}$ & $\begin{array}{l}\text { Reference } \\
\text { Model Architec- } \\
\text { ture (p. 31) }\end{array}$ \\
\hline $\begin{array}{l}\text { Institute for Interconnecting } \\
\text { and Packaging Electronics Cur- } \\
\text { cuits (IPC) }\end{array}$ & $\begin{array}{l}\text { North- } \\
\text { brook, IL }\end{array}$ & $\begin{array}{l}\text { Trade association for companies in the electronic inter- } \\
\text { connection industry. }\end{array}$ & $\begin{array}{l}\text { Internet Com- } \\
\text { merce for Man- } \\
\text { ufacturing (p. } \\
\text { 22) }\end{array}$ \\
\hline
\end{tabular}




\begin{tabular}{|c|c|c|c|}
\hline \multicolumn{4}{|c|}{ Consortia, National Programs, Professional and Trade Associations } \\
\hline Name & Location & Description & $\begin{array}{l}\text { Collaborating } \\
\text { Project(s) }\end{array}$ \\
\hline $\begin{array}{l}\text { Institute of Advanced Manu- } \\
\text { facturing Sciences (IAMS) }\end{array}$ & $\begin{array}{l}\text { Cincinnati, } \\
\mathrm{OH}\end{array}$ & $\begin{array}{l}\text { Not-for-profit organization for manufacturers, offering } \\
\text { solution-focused implementation of change in manufac- } \\
\text { turing operations. }\end{array}$ & $\begin{array}{l}\text { Design - Process } \\
\text { Planning Inte- } \\
\text { gration (DPPI) } \\
\text { (p. 16) } \\
\text { Information } \\
\text { Exchange Proto- } \\
\text { cols for Design } \\
\text { (p. 20) }\end{array}$ \\
\hline $\begin{array}{l}\text { Intelligent Manufacturing Sys- } \\
\text { tems (IMS) MISSION Project }\end{array}$ & $\begin{array}{l}\text { Tokyo, } \\
\text { Japan }\end{array}$ & $\begin{array}{l}\text { The primary objective of MISSION is a bridge from } \\
\text { today's tools and regionally-oriented factory design pro- } \\
\text { cesses into those needed for extended enterprises and/or } \\
\text { virtual enterprise networks. }\end{array}$ & $\begin{array}{l}\text { Production and } \\
\text { Product Data } \\
\text { Management } \\
\text { Applications (p. } \\
\text { 29) }\end{array}$ \\
\hline Knowledge-based Organization & $\mathrm{n} / \mathrm{a}$ & $\begin{array}{l}\text { A loosely based conglomerate of companies dedicated to } \\
\text { incorporating knowledged-based systems into their busi- } \\
\text { nesses. }\end{array}$ & $\begin{array}{l}\text { Information } \\
\text { Exchange Proto- } \\
\text { cols for Design } \\
\text { (p. 20) }\end{array}$ \\
\hline $\begin{array}{l}\text { National Electronics Manufac- } \\
\text { turing Initiative }\end{array}$ & $\begin{array}{l}\text { Herndon, } \\
\text { VA }\end{array}$ & $\begin{array}{l}\text { Consortium dedicated to facilitating long-term North } \\
\text { American leadership in volume electronics manufactur- } \\
\text { ing. }\end{array}$ & $\begin{array}{l}\text { Electronic Com- } \\
\text { merce for the } \\
\text { Electronics } \\
\text { Industry (ECEI) } \\
\text { (p. 17) }\end{array}$ \\
\hline $\begin{array}{l}\text { National Industrial Informa- } \\
\text { tion Infrastructure Protocols } \\
\text { (NIII) }\end{array}$ & $\begin{array}{l}\text { Stamford, } \\
\text { CT }\end{array}$ & $\begin{array}{l}\text { The NIIIP consortium's objective is to develop open } \\
\text { industry software protocols that will make it possible for } \\
\text { manufacturers and their suppliers to interoperate effec- } \\
\text { tively as if they were part of the same enterprise. The } \\
\text { consortium includes IBM, Digital Equipment Corpora- } \\
\text { tion, Enterprise Integration Technologies, General } \\
\text { Dynamics, Lockheed Aeronautical Systems, Magnavox, } \\
\text { Texas Instruments, and other participants. }\end{array}$ & $\begin{array}{l}\text { Enterprise } \\
\text { Resource Plan- } \\
\text { ning Interfaces } \\
\text { (ERP-I) (p. 19) } \\
\text { Framework (p. } \\
\text { 24) } \\
\text { STEP Conform- } \\
\text { ance and } \\
\text { Interoperability } \\
\text { Testing (p. 33) }\end{array}$ \\
\hline $\begin{array}{l}\text { Next Generation Inspection } \\
\text { System Program }\end{array}$ & $\begin{array}{l}\text { Ann Arbor, } \\
\text { MI }\end{array}$ & $\begin{array}{l}\text { NGIS is a program of the National Center for Manufac- } \\
\text { turing Sciences, Production Equipment and Systems } \\
\text { Special Interest Group. The objective is to develop next- } \\
\text { generation inspection capabilities on coordinate measur- } \\
\text { ing machines and machine tools. }\end{array}$ & $\begin{array}{l}\text { Reference } \\
\text { Model Architec- } \\
\text { ture (p. } 31 \text { ) }\end{array}$ \\
\hline $\begin{array}{l}\text { Open Modular Architecture } \\
\text { Control (OMAC) }\end{array}$ & $\begin{array}{l}\text { Oak Ridge, } \\
\text { TN }\end{array}$ & $\begin{array}{l}\text { OMAC seeks to develop an Open Architecture, Applica- } \\
\text { tion Programming Interface (API) for machine control- } \\
\text { lers }\end{array}$ & $\begin{array}{l}\text { Reference } \\
\text { Model Architec- } \\
\text { ture (p. } 31 \text { ) }\end{array}$ \\
\hline
\end{tabular}




\begin{tabular}{|c|c|c|c|}
\hline \multicolumn{4}{|c|}{ Consortia, National Programs, Professional and Trade Associations } \\
\hline Name & Location & Description & $\begin{array}{l}\text { Collaborating } \\
\text { Project(s) }\end{array}$ \\
\hline PDES, Inc. & $\begin{array}{l}\text { Charles- } \\
\text { ton, SC }\end{array}$ & $\begin{array}{l}\text { The PDES, Inc. consortium's objective is to accelerate } \\
\text { the development and implementation of STEP. The con- } \\
\text { sortium includes the South Carolina Research Authority, } \\
\text { Boeing, Ford, General Motors, Hughes, Lockheed Mar- } \\
\text { tin, Northrop Grumman, and other participants. }\end{array}$ & $\begin{array}{l}\text { Application Pro- } \\
\text { tocol Develop- } \\
\text { ment } \\
\text { Environment } \\
\text { (APDE) (p. 14) } \\
\text { Design - Process } \\
\text { Planning Inte- } \\
\text { gration (DPPI) } \\
\text { (p. 16) } \\
\text { Electronic Com- } \\
\text { merce for the } \\
\text { Electronics } \\
\text { Industry (ECEI) } \\
\text { (p. 17) } \\
\text { STEP Conform- } \\
\text { ance and } \\
\text { Interoperability } \\
\text { Testing (p. 33) }\end{array}$ \\
\hline $\begin{array}{l}\text { PIEBASE (Process Industry } \\
\text { Executive for achieving Busi- } \\
\text { ness Advantage using Stan- } \\
\text { dards for data Exchange) }\end{array}$ & $\begin{array}{l}\text { London, } \\
\text { UK }\end{array}$ & $\begin{array}{l}\text { PIEBASE is a global umbrella that coordinates develop- } \\
\text { ment and implementation of data exchange and data- } \\
\text { sharing standards for the process plant industry consortia } \\
\text { and member companies. }\end{array}$ & $\begin{array}{l}\text { STEP for the } \\
\text { Process Plant } \\
\text { Industries (p. } \\
\text { 35) }\end{array}$ \\
\hline PlantSTEP, Inc. & $\begin{array}{l}\text { Wilming- } \\
\text { ton, DE }\end{array}$ & $\begin{array}{l}\text { PlantSTEP, Inc. is a consortium working to support the } \\
\text { development of information exchange standards to } \\
\text { advance the capabilities of process plant and construc- } \\
\text { tion industries. Members include DuPont, Merck, Black } \\
\& \text { Veach, Bechtel, Intergraph, Computervision, and } \\
\text { CAD Centre. }\end{array}$ & $\begin{array}{l}\text { Application Pro- } \\
\text { tocol Develop- } \\
\text { ment } \\
\text { Environment } \\
\text { (APDE) (p. 14) } \\
\text { STEP for the } \\
\text { Process Plant } \\
\text { Industries (p. } \\
\text { 35) }\end{array}$ \\
\hline $\begin{array}{l}\text { POSC (Petrotechnical Open } \\
\text { Software Corporation) }\end{array}$ & $\begin{array}{l}\text { Houston, } \\
\text { TX }\end{array}$ & $\begin{array}{l}\text { A not-for-profit corporation dedicated to facilitating } \\
\text { integrated business processes and computing technology } \\
\text { for the exploration and production segment of the inter- } \\
\text { national petroleum industry. }\end{array}$ & $\begin{array}{l}\text { STEP for the } \\
\text { Process Plant } \\
\text { Industries (p. } \\
\text { 35) }\end{array}$ \\
\hline $\begin{array}{l}\text { Process Data eXchange Insti- } \\
\text { tute of AIChE (pdXi) }\end{array}$ & $\begin{array}{l}\text { New York, } \\
\text { NY }\end{array}$ & $\begin{array}{l}\text { pdXi is an industry trade group working to develop and } \\
\text { maintain open approaches to electronic data exchange } \\
\text { and management of process engineering data. Members } \\
\text { include DuPont, Exxon, and Simulation Sciences, Union } \\
\text { Carbide, and others. }\end{array}$ & $\begin{array}{l}\text { STEP for the } \\
\text { Process Plant } \\
\text { Industries (p. } \\
\text { 35) }\end{array}$ \\
\hline $\begin{array}{l}\text { Process Interchange Format } \\
\text { Group }\end{array}$ & Manoa, HI & Informal industry and academic consortium. & $\begin{array}{l}\text { Process Specifi- } \\
\text { cation Lan- } \\
\text { guage (p. } 27)\end{array}$ \\
\hline $\begin{array}{l}\text { Rapid Prototyping Association } \\
\text { of the Society of Manufactur- } \\
\text { ing Engineers }\end{array}$ & $\begin{array}{l}\text { Dearborn, } \\
\text { MI }\end{array}$ & $\begin{array}{l}\text { Association seeking to communicate the vision and } \\
\text { direction of rapid prototyping technology to users. }\end{array}$ & $\begin{array}{l}\text { Information } \\
\text { Exchange Proto- } \\
\text { cols for Design } \\
\text { (p. 20) }\end{array}$ \\
\hline
\end{tabular}




\begin{tabular}{|c|c|c|c|}
\hline \multicolumn{4}{|c|}{ Consortia, National Programs, Professional and Trade Associations } \\
\hline Name & Location & Description & $\begin{array}{l}\text { Collaborating } \\
\text { Project(s) }\end{array}$ \\
\hline Rapid Response Manufacturing & $\begin{array}{l}\text { Ann Arbor, } \\
\text { MI }\end{array}$ & $\begin{array}{l}\text { The RRM consortium's objective is to increase first } \\
\text { product quality while decreasing design to manufactur- } \\
\text { ing cycle time. The RRM consortium includes the } \\
\text { National Center for Manufacturing Sciences (NCMS), } \\
\text { General Motors, Ford Motor, Texas Instruments, United } \\
\text { Technologies, Lockheed Martin Energy Systems, and } \\
\text { other participants. }\end{array}$ & $\begin{array}{l}\text { Information } \\
\text { Exchange Proto- } \\
\text { cols for Design } \\
\text { (p. 20) } \\
\text { Framework (p. } \\
24 \text { ) } \\
\text { Production and } \\
\text { Product Data } \\
\text { Management } \\
\text { Applications (p. } \\
\text { 29) }\end{array}$ \\
\hline $\begin{array}{l}\text { Research Collaboratory for } \\
\text { Structural Bioinformatics } \\
(\text { RCSB) }\end{array}$ & $\begin{array}{l}\text { Piscat- } \\
\text { away, NJ }\end{array}$ & $\begin{array}{l}\text { A non-profit consortium dedicated to improving our } \\
\text { understanding of the function of biological systems } \\
\text { through an understanding of 3-dimensional biological } \\
\text { macromolecular structure. }\end{array}$ & $\begin{array}{l}\text { Web-Based Bio- } \\
\text { informatics } \\
\text { Databases (p. } \\
43 \text { ) }\end{array}$ \\
\hline RosettaNet & $\begin{array}{l}\text { Los Ange- } \\
\text { les, CA }\end{array}$ & $\begin{array}{l}\text { Consortium dedicated to development of industry-wide } \\
\text { electronic business operability standards. }\end{array}$ & $\begin{array}{l}\text { Internet Com- } \\
\text { merce for Man- } \\
\text { ufacturing (p. } \\
\text { 22) }\end{array}$ \\
\hline SEMATECH & Austin, TX & $\begin{array}{l}\text { The SEMATECH consortium's objective is to sponsor } \\
\text { and conduct research aimed at assuring leadership in } \\
\text { semiconductor manufacturing technology for the U.S. } \\
\text { semiconductor industry. The consortium includes } \\
\text { Advanced Micro Devices, Digital Equipment Corpora- } \\
\text { tion, Hewlett-Packard, Intel, IBM, Lucent Technologies, } \\
\text { Motorola, National Semiconductor Corporation, Rock- } \\
\text { well International, and Texas Instruments. }\end{array}$ & $\begin{array}{l}\text { Electronic Com- } \\
\text { merce for the } \\
\text { Electronics } \\
\text { Industry (ECEI) } \\
\text { (p. 17) } \\
\text { Framework (p. } \\
\text { 24) } \\
\text { Production and } \\
\text { Product Data } \\
\text { Management } \\
\text { Applications (p. } \\
\text { 29) } \\
\text { Analysis Tools } \\
\text { for Assessment } \\
\text { and Optimiza- } \\
\text { tion of Process } \\
\text { and Product } \\
\text { Design (p. 37) }\end{array}$ \\
\hline Silicon Integration Initiative & Austin, TX & $\begin{array}{l}\text { Organization of industry-leading silicon systems and } \\
\text { tool companies focused on improving productivity and } \\
\text { reducing cost in creating and producing integrated sili- } \\
\text { con systems. }\end{array}$ & $\begin{array}{l}\text { Electronic Com- } \\
\text { merce for the } \\
\text { Electronics } \\
\text { Industry (ECEI) } \\
\text { (p. 17) }\end{array}$ \\
\hline $\begin{array}{l}\text { Software Engineering Institute } \\
\text { (SEI) }\end{array}$ & $\begin{array}{l}\text { Pittsburgh, } \\
\text { PA }\end{array}$ & $\begin{array}{l}\text { Department of Defense-funded R\&D center tasked to } \\
\text { provide leadership in advancing the state of the practice } \\
\text { of software engineering to improve the quality of sys- } \\
\text { tems that depend on software. }\end{array}$ & $\begin{array}{l}\text { Framework (p. } \\
24)\end{array}$ \\
\hline
\end{tabular}




\begin{tabular}{|c|c|c|c|}
\hline \multicolumn{4}{|c|}{ Consortia, National Programs, Professional and Trade Associations } \\
\hline Name & Location & Description & $\begin{array}{l}\text { Collaborating } \\
\text { Project(s) }\end{array}$ \\
\hline $\begin{array}{l}\text { Surface Mount Equipment } \\
\text { Manufacturers Association } \\
\text { (SMEMA) }\end{array}$ & $\begin{array}{l}\text { Highland } \\
\text { Park, IL }\end{array}$ & $\begin{array}{l}\text { A non-profit organization of companies manufacturing } \\
\text { equipment or producing software for surface mount } \\
\text { board production. }\end{array}$ & $\begin{array}{l}\text { Electronic Com- } \\
\text { merce for the } \\
\text { Electronics } \\
\text { Industry (ECEI) } \\
\text { (p. 17) } \\
\text { Internet Com- } \\
\text { merce for Man- } \\
\text { ufacturing (p. } \\
22 \text { ) }\end{array}$ \\
\hline Supply Chain Council & $\begin{array}{l}\text { Pittsburgh, } \\
\text { PA }\end{array}$ & $\begin{array}{l}\text { A cross-industry consortium formed to establish a } \\
\text { framework to enable manufacturers and their supply- } \\
\text { chain vendors to build a stronger supply chain and reap } \\
\text { the competitive rewards of improved supply-chain man- } \\
\text { agement. }\end{array}$ & $\begin{array}{l}\text { Enterprise } \\
\text { Resource Plan- } \\
\text { ning Interfaces } \\
(\text { ERP-I) (p. 19) }\end{array}$ \\
\hline $\begin{array}{l}\text { Technologies Enabling Agile } \\
\text { Manufacturing (TEAM) }\end{array}$ & $\begin{array}{l}\text { Oak Ridge, } \\
\text { TN }\end{array}$ & $\begin{array}{l}\text { The TEAM consortium's objective is to enhance } \\
\text { national industrial competitiveness by advancing and } \\
\text { deploying manufacturing technologies that promote agil- } \\
\text { ity. The consortium includes American firms and consor- } \\
\text { tia representing many industrial sectors including } \\
\text { aerospace, automotive, consumer electronics, and soft- } \\
\text { ware along with multiple federal agencies and facilities. }\end{array}$ & $\begin{array}{l}\text { Design - Process } \\
\text { Planning Inte- } \\
\text { gration (DPPI) } \\
\text { (p. 16) } \\
\text { Information } \\
\text { Exchange Proto- } \\
\text { cols for Design } \\
\text { (p. 20) } \\
\text { Framework (p. } \\
\text { 24) } \\
\text { Reference } \\
\text { Model Architec- } \\
\text { ture (p. 31) }\end{array}$ \\
\hline VSI Alliance & $\begin{array}{l}\text { Los Gatos, } \\
\text { CA }\end{array}$ & $\begin{array}{l}\text { The VSI Alliance is chartered to define, develop, autho- } \\
\text { rize, test, and promote open standard specifications relat- } \\
\text { ing to data formats, test methodologies, and interfaces. } \\
\text { These standards are to facilitate the mix and match and } \\
\text { the reuse of blocks of electronic circuit functions from } \\
\text { different sources in the design and development of sys- } \\
\text { tem-level ICs. }\end{array}$ & $\begin{array}{l}\text { Electronic Com- } \\
\text { merce for the } \\
\text { Electronics } \\
\text { Industry (ECEI) } \\
\text { (p. 17) }\end{array}$ \\
\hline
\end{tabular}




\begin{tabular}{|c|c|c|c|}
\hline \multicolumn{4}{|c|}{ Individual Companies } \\
\hline Name & Location & Description & $\begin{array}{l}\text { Collaborating } \\
\text { Project(s) }\end{array}$ \\
\hline $\begin{array}{l}\text { Advanced Manufacturing } \\
\text { Research }\end{array}$ & $\begin{array}{l}\text { Boston, } \\
\text { MA }\end{array}$ & $\begin{array}{l}\text { Industry and market analysis firm specializing in enter- } \\
\text { prise applications and related trends and technologies. }\end{array}$ & $\begin{array}{l}\text { Enterprise } \\
\text { Resource Plan- } \\
\text { ning Interfaces } \\
(\text { ERP-I) (p. 19) }\end{array}$ \\
\hline Advanced Micro Devices, Inc. & Austin, TX & $\begin{array}{l}\text { Supplier of integrated circuits for the computer and com- } \\
\text { munications markets. }\end{array}$ & $\begin{array}{l}\text { Framework (p. } \\
\text { 24) } \\
\text { Analysis Tools } \\
\text { for Assessment } \\
\text { and Optimiza- } \\
\text { tion of Process } \\
\text { and Product } \\
\text { Design (p. 37) }\end{array}$ \\
\hline $\begin{array}{l}\text { Advanced Technology and } \\
\text { Research Corporation }\end{array}$ & $\begin{array}{l}\text { Burtons- } \\
\text { ville, MD }\end{array}$ & $\begin{array}{l}\text { Consultants specializing in research and development of } \\
\text { intelligent control systems, automation, robotics, simula- } \\
\text { tion, engineering analysis, and computer science. }\end{array}$ & $\begin{array}{l}\text { Reference } \\
\text { Model Architec- } \\
\text { ture (p. 31) }\end{array}$ \\
\hline AlliedSignal Kansas City Plant & $\begin{array}{l}\text { Kansas } \\
\text { City, MO }\end{array}$ & $\begin{array}{l}\text { Manufacturer of electrical, mechanical, and engineered } \\
\text { materials for weapons production. }\end{array}$ & $\begin{array}{l}\text { Information } \\
\text { Exchange Proto- } \\
\text { cols for Design } \\
\text { (p. 20) }\end{array}$ \\
\hline AMP, Inc. & $\begin{array}{l}\text { Harris- } \\
\text { burg, PA }\end{array}$ & Manufacturer of electronic connectors. & $\begin{array}{l}\text { Production and } \\
\text { Product Data } \\
\text { Management } \\
\text { Applications (p. } \\
\text { 29) }\end{array}$ \\
\hline Automata Design, Inc. & $\begin{array}{l}\text { Herndon, } \\
\text { VA }\end{array}$ & $\begin{array}{l}\text { Vendor of software simulating circuit board design and } \\
\text { production processes. }\end{array}$ & $\begin{array}{l}\text { Internet Com- } \\
\text { merce for Man- } \\
\text { ufacturing (p. } \\
22 \text { ) }\end{array}$ \\
\hline AutoSimulation, Inc. & $\begin{array}{l}\text { Bountiful, } \\
\text { UT }\end{array}$ & Vendor of simulation and scheduling software. & $\begin{array}{l}\text { Production and } \\
\text { Product Data } \\
\text { Management } \\
\text { Applications (p. } \\
\text { 29) }\end{array}$ \\
\hline Bechtel & $\begin{array}{l}\text { San Fran- } \\
\text { cisco, CA }\end{array}$ & $\begin{array}{l}\text { Provider of services to develop, engineer, construct, and } \\
\text { manage capital projects and facilities worldwide. }\end{array}$ & $\begin{array}{l}\text { STEP for the } \\
\text { Process Plant } \\
\text { Industries (p. } \\
35)\end{array}$ \\
\hline B.F. Goodrich Corporation & $\begin{array}{l}\text { Cleveland, } \\
\mathrm{OH}\end{array}$ & Aerospace and performance products manufacturer. & $\begin{array}{l}\text { Production and } \\
\text { Product Data } \\
\text { Management } \\
\text { Applications (p. } \\
\text { 29) }\end{array}$ \\
\hline
\end{tabular}




\begin{tabular}{|c|c|c|c|}
\hline \multicolumn{4}{|c|}{ Individual Companies } \\
\hline Name & Location & Description & $\begin{array}{l}\text { Collaborating } \\
\text { Project(s) }\end{array}$ \\
\hline Black and Decker & $\begin{array}{l}\text { Towson, } \\
\text { MD }\end{array}$ & $\begin{array}{l}\text { Manufacturer of portable power tools and household } \\
\text { appliances. }\end{array}$ & $\begin{array}{l}\text { Information } \\
\text { Exchange Proto- } \\
\text { cols for Design } \\
\text { (p. 20) } \\
\text { Production and } \\
\text { Product Data } \\
\text { Management } \\
\text { Applications (p. } \\
\text { 29) } \\
\text { Virtual Environ- } \\
\text { ments and Visu- } \\
\text { alization for } \\
\text { Manufacturing } \\
\text { (p. 36) }\end{array}$ \\
\hline Black \& Veatch & $\begin{array}{l}\text { Kansas } \\
\text { City, MO }\end{array}$ & An engineering construction company. & $\begin{array}{l}\text { STEP for the } \\
\text { Process Plant } \\
\text { Industries (p. } \\
\text { 35) }\end{array}$ \\
\hline Boeing & $\begin{array}{l}\text { Seattle, } \\
\text { WA }\end{array}$ & Aerospace manufacturer. & $\begin{array}{l}\text { Application Pro- } \\
\text { tocol Develop- } \\
\text { ment } \\
\text { Environment } \\
\text { (APDE) (p. 14) } \\
\text { Information } \\
\text { Exchange Proto- } \\
\text { cols for Design } \\
\text { (p. 20) }\end{array}$ \\
\hline $\begin{array}{l}\text { Boeing Commercial Airplane } \\
\text { Group }\end{array}$ & $\begin{array}{l}\text { Seattle, } \\
\text { WA }\end{array}$ & Manufacturer of commercial aircraft. & $\begin{array}{l}\text { STEP Conform- } \\
\text { ance and } \\
\text { Interoperability } \\
\text { Testing (p. 33) }\end{array}$ \\
\hline Boeing Helicopters & $\begin{array}{l}\text { Philadel- } \\
\text { phia, PA }\end{array}$ & Manufacturer of rotary-wing aircraft. & $\begin{array}{l}\text { Process Specifi- } \\
\text { cation Lan- } \\
\text { guage (p. 27) }\end{array}$ \\
\hline CAMAX & $\begin{array}{l}\text { Eugene, } \\
\text { OR }\end{array}$ & Vendor of computer-aided manufacturing software. & $\begin{array}{l}\text { Design - Process } \\
\text { Planning Inte- } \\
\text { gration (DPPI) } \\
\text { (p. 16) }\end{array}$ \\
\hline Caterpillar & Peoria, IL & Manufacturer of heavy earth-moving equipment. & $\begin{array}{l}\text { Information } \\
\text { Exchange Proto- } \\
\text { cols for Design } \\
\text { (p. 20) }\end{array}$ \\
\hline CIMx & $\begin{array}{l}\text { Cincinnati, } \\
\mathrm{OH}\end{array}$ & $\begin{array}{l}\text { Vendor of software systems for discrete manufacturing } \\
\text { applications. }\end{array}$ & $\begin{array}{l}\text { Design - Process } \\
\text { Planning Inte- } \\
\text { gration (DPPI) } \\
\text { (p. 16) }\end{array}$ \\
\hline
\end{tabular}




\section{Collaborators}

\begin{tabular}{|c|c|c|c|}
\hline \multicolumn{4}{|c|}{ Individual Companies } \\
\hline Name & Location & Description & $\begin{array}{l}\text { Collaborating } \\
\text { Project(s) }\end{array}$ \\
\hline Clearwater Technical Services & $\begin{array}{l}\text { Yung- } \\
\text { aburra, } \\
\text { Australia }\end{array}$ & $\begin{array}{l}\text { A consulting firm specializing in custom software devel- } \\
\text { opment and network support. }\end{array}$ & $\begin{array}{l}\text { Operator Inter- } \\
\text { faces for Virtual } \\
\text { and Distributed } \\
\text { Manufacturing } \\
\text { (p. 26) }\end{array}$ \\
\hline CNC Software, Inc. & $\begin{array}{l}\text { Tolland, } \\
\text { CT }\end{array}$ & $\begin{array}{l}\text { Vendor of software tools for the CAD/CAM manufactur- } \\
\text { ing markets. }\end{array}$ & $\begin{array}{l}\text { Design - Process } \\
\text { Planning Inte- } \\
\text { gration (DPPI) } \\
\text { (p. 16) }\end{array}$ \\
\hline Computer Data Systems, Inc. & $\begin{array}{l}\text { Rockville, } \\
\text { MD }\end{array}$ & $\begin{array}{l}\text { Provides data processing and professional computer ser- } \\
\text { vices and products. }\end{array}$ & $\begin{array}{l}\text { Web-based Test- } \\
\text { ing Service for } \\
\text { Coordinate } \\
\text { Measuring } \\
\text { Machine } \\
\text { (CMM) Soft- } \\
\text { ware (p. 39) }\end{array}$ \\
\hline $\begin{array}{l}\text { Concurrent Technologies Cor- } \\
\text { poration }\end{array}$ & $\begin{array}{l}\text { Johnstown, } \\
\text { PA }\end{array}$ & $\begin{array}{l}\text { A non-profit company chartered to take technology from } \\
\text { research labs to the commercial workplace. }\end{array}$ & $\begin{array}{l}\text { Application Pro- } \\
\text { tocol Develop- } \\
\text { ment } \\
\text { Environment } \\
\text { (APDE) (p. 14) }\end{array}$ \\
\hline Delphi Delco & $\begin{array}{l}\text { Indianapo- } \\
\text { lis, IN }\end{array}$ & Electronics manufacturer. & $\begin{array}{l}\text { Application Pro- } \\
\text { tocol Develop- } \\
\text { ment } \\
\text { Environment } \\
\text { (APDE) (p. 14) }\end{array}$ \\
\hline Deneb Robotics & $\begin{array}{l}\text { Auburn } \\
\text { Hills, MI }\end{array}$ & $\begin{array}{l}\text { Vendor of 3D graphics-based factory simulation, telero- } \\
\text { botic, and virtual reality software. }\end{array}$ & $\begin{array}{l}\text { Operator Inter- } \\
\text { faces for Virtual } \\
\text { and Distributed } \\
\text { Manufacturing } \\
\text { (p. 26) } \\
\text { Production and } \\
\text { Product Data } \\
\text { Management } \\
\text { Applications (p. } \\
\text { 29) } \\
\text { Virtual Environ- } \\
\text { ments and Visu- } \\
\text { alization for } \\
\text { Manufacturing } \\
\text { (p. 36) }\end{array}$ \\
\hline $\begin{array}{l}\text { D.H. Brown Associates } \\
\text { (DHBA) }\end{array}$ & $\begin{array}{l}\text { Port Ches- } \\
\text { ter, NY }\end{array}$ & $\begin{array}{l}\text { DHBA is a research analysis firm specializing in analy- } \\
\text { sis of technologies to support computer environments for } \\
\text { engineering, manufacturing, design, and open systems. }\end{array}$ & $\begin{array}{l}\text { Information } \\
\text { Exchange Proto- } \\
\text { cols for Design } \\
\text { (p. 20) }\end{array}$ \\
\hline
\end{tabular}




\begin{tabular}{|c|c|c|c|}
\hline \multicolumn{4}{|c|}{ Individual Companies } \\
\hline Name & Location & Description & $\begin{array}{l}\text { Collaborating } \\
\text { Project(s) }\end{array}$ \\
\hline DLOG Corporation & $\begin{array}{l}\text { Chicago, } \\
\text { IL }\end{array}$ & Vendor of shop floor data collection software. & $\begin{array}{l}\text { Production and } \\
\text { Product Data } \\
\text { Management } \\
\text { Applications (p. } \\
\text { 29) }\end{array}$ \\
\hline Dow Chemical Company & $\begin{array}{l}\text { Midland, } \\
\text { MI }\end{array}$ & $\begin{array}{l}\text { The Dow Chemical Company provides chemicals, plas- } \\
\text { tics, energy, agricultural products, consumer goods and } \\
\text { environmental services. }\end{array}$ & $\begin{array}{l}\text { Online Access } \\
\text { to NIST Chemi- } \\
\text { cal Reference } \\
\text { Data (p. 42) }\end{array}$ \\
\hline Dupont & $\begin{array}{l}\text { Wilming- } \\
\text { ton, DE }\end{array}$ & An energy and chemistry-based company. & $\begin{array}{l}\text { STEP for the } \\
\text { Process Plant } \\
\text { Industries }(\mathrm{p} \text {. } \\
\text { 35) }\end{array}$ \\
\hline $\begin{array}{l}\text { Dupont-Merck Pharmaceutical } \\
\text { Co. }\end{array}$ & $\begin{array}{l}\text { Wilming- } \\
\text { ton, DE }\end{array}$ & $\begin{array}{l}\text { A company focusing on research, development and } \\
\text { delivery of pharmaceuticals to treat currently unmet } \\
\text { medical needs }\end{array}$ & $\begin{array}{l}\text { Web-Based Bio- } \\
\text { informatics } \\
\text { Databases (p. } \\
\text { 43) }\end{array}$ \\
\hline $\begin{array}{l}\text { Fachinformationszentrum } \\
\text { Karlsruhe Gesellschaft für wis- } \\
\text { senschaftlich-technische Infor- } \\
\text { mation mbH }\end{array}$ & $\begin{array}{l}\text { Karlsruhe, } \\
\text { Germany }\end{array}$ & $\begin{array}{l}\text { A non-profit organization set up to provide information } \\
\text { and information services for academic and industrial } \\
\text { research \& development, as well as for business and } \\
\text { administration. }\end{array}$ & $\begin{array}{l}\text { Computerized } \\
\text { Access to Full } \\
\text { Structural Crys- } \\
\text { tallographic } \\
\text { Data (p. 40) }\end{array}$ \\
\hline Gartner Group & $\begin{array}{l}\text { Stamford, } \\
\text { CT }\end{array}$ & $\begin{array}{l}\text { Research and consulting firm specializing in the infor- } \\
\text { mation technology arena. }\end{array}$ & $\begin{array}{l}\text { Enterprise } \\
\text { Resource Plan- } \\
\text { ning Interfaces } \\
(\text { ERP-I) (p. 19) }\end{array}$ \\
\hline $\begin{array}{l}\text { General Engineering and Sys- } \\
\text { tems Analysis Co. (GESAC) }\end{array}$ & $\begin{array}{l}\text { Boons- } \\
\text { boro, MD }\end{array}$ & $\begin{array}{l}\text { Engineering consulting firm and manufacturer of crash } \\
\text { test dummies. }\end{array}$ & $\begin{array}{l}\text { Information } \\
\text { Exchange Proto- } \\
\text { cols for Design } \\
\text { (p. 20) }\end{array}$ \\
\hline General Motors Corporation & Detroit, MI & Large industrial corporation and vehicle manufacturer. & $\begin{array}{l}\text { NIST Manufac- } \\
\text { turing Collabo- } \\
\text { ratory (p. } 45)\end{array}$ \\
\hline GenRad, Inc. & $\begin{array}{l}\text { Westford, } \\
\text { MA }\end{array}$ & $\begin{array}{l}\text { Supplies electronics OEMs and their customers with } \\
\text { hardware, software, inspection systems and services to } \\
\text { optimize design, manufacturing and aftermarket service } \\
\text { productivity. }\end{array}$ & $\begin{array}{l}\text { Internet Com- } \\
\text { merce for Man- } \\
\text { ufacturing (p. } \\
\text { 22) }\end{array}$ \\
\hline Hewlett-Packard & $\begin{array}{l}\text { Palo Alto, } \\
\text { CA }\end{array}$ & $\begin{array}{l}\text { Producer of Computers and test and measurement equip- } \\
\text { ment. }\end{array}$ & $\begin{array}{l}\text { Internet Com- } \\
\text { merce for Man- } \\
\text { ufacturing }(p . \\
22)\end{array}$ \\
\hline Honeywell & $\begin{array}{l}\text { Minneapo- } \\
\text { lis, MN }\end{array}$ & $\begin{array}{l}\text { Supplier of automation and control systems, compo- } \\
\text { nents, software, products and services for homes, indus- } \\
\text { try, and aerospace. }\end{array}$ & $\begin{array}{l}\text { Framework (p. } \\
\text { 24) }\end{array}$ \\
\hline
\end{tabular}




\section{Collaborators}

\begin{tabular}{|c|c|c|c|}
\hline \multicolumn{4}{|c|}{ Individual Companies } \\
\hline Name & Location & Description & $\begin{array}{l}\text { Collaborating } \\
\text { Project(s) }\end{array}$ \\
\hline Hypertek, Inc. & $\begin{array}{l}\text { Gaithers- } \\
\text { burg, MD }\end{array}$ & Independent computer consultant. & $\begin{array}{l}\text { Standards for } \\
\text { Exchange of } \\
\text { Instrument Data } \\
\text { and NIST } \\
\text { Chemical Refer- } \\
\text { ence Data (p. } \\
\text { 43) }\end{array}$ \\
\hline IBM & $\begin{array}{l}\text { White } \\
\text { Plains, NY }\end{array}$ & Large information technology corporation. & $\begin{array}{l}\text { Information } \\
\text { Exchange Proto- } \\
\text { cols for Design } \\
\text { (p. 20) }\end{array}$ \\
\hline $\begin{array}{l}\text { Information Management } \\
\text { Resources, Inc. }\end{array}$ & $\begin{array}{l}\text { Gaithers- } \\
\text { burg, MD }\end{array}$ & $\begin{array}{l}\text { An independent computer consulting firm specializing in } \\
\text { database and client/server applications. }\end{array}$ & $\begin{array}{l}\text { Standards for } \\
\text { Exchange of } \\
\text { Instrument Data } \\
\text { and NIST } \\
\text { Chemical Refer- } \\
\text { ence Data (p. } \\
43 \text { ) }\end{array}$ \\
\hline $\begin{array}{l}\text { InterData Access, Inc. } \\
\text { (formerly IGES Data Analysis) }\end{array}$ & $\begin{array}{l}\text { Westches- } \\
\text { ter, IL }\end{array}$ & $\begin{array}{l}\text { Consulting firm specializing in the sharing, access and } \\
\text { exchange of electronic product data used throughout the } \\
\text { design and manufacturing process chain. }\end{array}$ & $\begin{array}{l}\text { Electronic Com- } \\
\text { merce for the } \\
\text { Electronics } \\
\text { Industry (ECEI) } \\
\text { (p. 17) }\end{array}$ \\
\hline Intelligent Automation, Inc. & $\begin{array}{l}\text { Rockville, } \\
\text { MD }\end{array}$ & $\begin{array}{l}\text { R\&D and consulting firm specializing in Artificial Intel- } \\
\text { ligence applications. }\end{array}$ & $\begin{array}{l}\text { Framework (p. } \\
24)\end{array}$ \\
\hline $\begin{array}{l}\text { Knowledge Based Systems, } \\
\text { Inc. }\end{array}$ & $\begin{array}{l}\text { College } \\
\text { Station, TX }\end{array}$ & $\begin{array}{l}\text { Vendor of software products for process modeling and } \\
\text { analysis. }\end{array}$ & $\begin{array}{l}\text { Process Specifi- } \\
\text { cation Lan- } \\
\text { guage (p. 27) }\end{array}$ \\
\hline Knowledge Revolution & $\begin{array}{l}\text { San Mateo, } \\
\text { CA }\end{array}$ & $\begin{array}{l}\text { Producer of functional motion simulation software for } \\
\text { engineering, visualization, and education. }\end{array}$ & $\begin{array}{l}\text { Virtual Environ- } \\
\text { ments and Visu- } \\
\text { alization for } \\
\text { Manufacturing } \\
\text { (p. 36) }\end{array}$ \\
\hline $\begin{array}{l}\text { Knowledge Technologies Inter- } \\
\text { national, Inc. }\end{array}$ & $\begin{array}{l}\text { Burling- } \\
\text { ton, MA }\end{array}$ & $\begin{array}{l}\text { An independent organization handling development, } \\
\text { marketing, sales and consulting services related to pro- } \\
\text { viding Knowledge-Based solutions to global manufac- } \\
\text { turing businesses. }\end{array}$ & $\begin{array}{l}\text { Information } \\
\text { Exchange Proto- } \\
\text { cols for Design } \\
\text { (p. 20) }\end{array}$ \\
\hline Merck \& Co., Inc. & $\begin{array}{l}\text { Somersett, } \\
\text { NJ }\end{array}$ & $\begin{array}{l}\text { A research-driven pharmaceutical products and services } \\
\text { company. }\end{array}$ & $\begin{array}{l}\text { STEP for the } \\
\text { Process Plant } \\
\text { Industries ( } \mathrm{p} \text {. } \\
\text { 35) }\end{array}$ \\
\hline
\end{tabular}




\begin{tabular}{|c|c|c|c|}
\hline \multicolumn{4}{|c|}{ Individual Companies } \\
\hline Name & Location & Description & $\begin{array}{l}\text { Collaborating } \\
\text { Project(s) }\end{array}$ \\
\hline $\begin{array}{l}\text { Michigan Manufacturing Tech- } \\
\text { nology Center (MMTC) } \\
\text { (formerly the Industrial Tech- } \\
\text { nology Institute) }\end{array}$ & $\begin{array}{l}\text { Ann Arbor, } \\
\text { MI }\end{array}$ & $\begin{array}{l}\text { Not-for-profit organization that provides training and } \\
\text { assistance to help companies meet customer require- } \\
\text { ments and industry standards, increase profits, improve } \\
\text { quality, and lower costs. }\end{array}$ & $\begin{array}{l}\text { Application Pro- } \\
\text { tocol Develop- } \\
\text { ment } \\
\text { Environment } \\
\text { (APDE) (p. 14) } \\
\text { Framework (p. } \\
\text { 24) } \\
\text { STEP Conform- } \\
\text { ance and } \\
\text { Interoperability } \\
\text { Testing (p. 33) }\end{array}$ \\
\hline Mitta Technology Group & $\begin{array}{l}\text { Sunnyvale, } \\
\text { CA }\end{array}$ & $\begin{array}{l}\text { A provider of integration and consulting services for } \\
\text { Factory Automation (FA) in the semiconductor and } \\
\text { related high-technology industries. }\end{array}$ & $\begin{array}{l}\text { Electronic Com- } \\
\text { merce for the } \\
\text { Electronics } \\
\text { Industry (ECEI) } \\
\text { (p. 17) }\end{array}$ \\
\hline Monsanto Chemical Company & $\begin{array}{l}\text { Bridge- } \\
\text { port, NJ }\end{array}$ & $\begin{array}{l}\text { (Formerly) a manufacturer of a wide range of chemical } \\
\text { products. }\end{array}$ & $\begin{array}{l}\text { Online Access } \\
\text { to NIST Chemi- } \\
\text { cal Reference } \\
\text { Data (p. 42) }\end{array}$ \\
\hline Motorola & $\begin{array}{l}\text { Schaum- } \\
\text { burg, IL }\end{array}$ & $\begin{array}{l}\text { Manufacturer of integrated circuits and wide variety of } \\
\text { semiconductor-based consumer products. }\end{array}$ & $\begin{array}{l}\text { Analysis Tools } \\
\text { for Assessment } \\
\text { and Optimiza- } \\
\text { tion of Process } \\
\text { and Product } \\
\text { Design (p. 37) }\end{array}$ \\
\hline Nihon Unisys & $\begin{array}{l}\text { Tokyo, } \\
\text { Japan }\end{array}$ & $\begin{array}{l}\text { Developer and integrator of information technology sys- } \\
\text { tems. }\end{array}$ & $\begin{array}{l}\text { Information } \\
\text { Exchange Proto- } \\
\text { cols for Design } \\
\text { (p. 20) }\end{array}$ \\
\hline OrcaComputers, Inc. & Fairfax, VA & Vendor of object-oriented simulation software. & $\begin{array}{l}\text { Production and } \\
\text { Product Data } \\
\text { Management } \\
\text { Applications (p. } \\
29 \text { ) }\end{array}$ \\
\hline OrCAD, Inc & $\begin{array}{l}\text { Beaverton } \\
\text { OR }\end{array}$ & $\begin{array}{l}\text { Producer of electronic design automation software prod- } \\
\text { ucts for the design of printed circuit boards, field-pro- } \\
\text { grammable gate arrays and complex programmable logic } \\
\text { devices. }\end{array}$ & $\begin{array}{l}\text { Internet Com- } \\
\text { merce for Man- } \\
\text { ufacturing }(p . \\
22)\end{array}$ \\
\hline PACCAR, Inc. & $\begin{array}{l}\text { Bellevue, } \\
\text { WA }\end{array}$ & Manufacturer of on and off-road trucks. & $\begin{array}{l}\text { Information } \\
\text { Exchange Proto- } \\
\text { cols for Design } \\
\text { (p. 20) }\end{array}$ \\
\hline Pritsker Corporation & $\begin{array}{l}\text { West } \\
\text { Lafayette, } \\
\text { IN }\end{array}$ & Vendor of simulation and scheduling software. & $\begin{array}{l}\text { Production and } \\
\text { Product Data } \\
\text { Management } \\
\text { Applications (p. } \\
\text { 29) }\end{array}$ \\
\hline
\end{tabular}




\section{Collaborators}

\begin{tabular}{|c|c|c|c|}
\hline \multicolumn{4}{|c|}{ Individual Companies } \\
\hline Name & Location & Description & $\begin{array}{l}\text { Collaborating } \\
\text { Project(s) }\end{array}$ \\
\hline Raytheon Electronic Systems & $\begin{array}{l}\text { Tewks- } \\
\text { bury, MA }\end{array}$ & Defense electronics firm. & $\begin{array}{l}\text { Process Specifi- } \\
\text { cation Lan- } \\
\text { guage (p. 27) }\end{array}$ \\
\hline Real Time Innovations, Inc. & $\begin{array}{l}\text { Sunnyvale, } \\
\text { CA }\end{array}$ & Vendor of real-time software development tools. & $\begin{array}{l}\text { Reference } \\
\text { Model Architec- } \\
\text { ture (p. 31) }\end{array}$ \\
\hline Rockwell Collins & $\begin{array}{l}\text { Cedar Rap- } \\
\text { ids, IA }\end{array}$ & $\begin{array}{l}\text { Manufacturer of communications and navigational elec- } \\
\text { tronics and avionics. }\end{array}$ & $\begin{array}{l}\text { Application Pro- } \\
\text { tocol Develop- } \\
\text { ment } \\
\text { Environment } \\
\text { (APDE) (p. 14) }\end{array}$ \\
\hline SoftQuad, Inc. & $\begin{array}{l}\text { Toronto, } \\
\text { Canada }\end{array}$ & $\begin{array}{l}\text { Vendor of Standard Generalized Markup Language } \\
\text { (SGML) software tools. }\end{array}$ & $\begin{array}{l}\text { Application Pro- } \\
\text { tocol Develop- } \\
\text { ment } \\
\text { Environment } \\
\text { (APDE) (p. 14) }\end{array}$ \\
\hline Solectron Corp. & $\begin{array}{l}\text { Milpitas, } \\
\text { CA }\end{array}$ & $\begin{array}{l}\text { Provides integrated solutions for the entire product cycle } \\
\text { from pre-production planning and design, to manufactur- } \\
\text { ing, distribution and end-of-life product service and sup- } \\
\text { port for electronics OEMs. }\end{array}$ & $\begin{array}{l}\text { Internet Com- } \\
\text { merce for Man- } \\
\text { ufacturing }(p . \\
22)\end{array}$ \\
\hline STEP Tools Inc. & Troy, NY & $\begin{array}{l}\text { Vendor of software tools that support the STEP (ISO } \\
\text { 10303) standard for data exchange and information mod- } \\
\text { eling. }\end{array}$ & $\begin{array}{l}\text { Application Pro- } \\
\text { tocol Develop- } \\
\text { ment } \\
\text { Environment } \\
\text { (APDE) (p. 14) } \\
\text { Process Specifi- } \\
\text { cation Lan- } \\
\text { guage (p. } 27 \text { ) }\end{array}$ \\
\hline $\begin{array}{l}\text { Sun Microsystems Laboratories } \\
\text { (SunLabs) }\end{array}$ & $\begin{array}{l}\text { Palo Alto, } \\
\text { CA }\end{array}$ & $\begin{array}{l}\text { Develops, demonstrates, and introduces new advanced } \\
\text { technology and technical methodologies for Sun Micro- } \\
\text { systems, Inc. and its subsidiary corporations. Maintains } \\
\text { an awareness of, and contact with, outside technical } \\
\text { activities in academia, government, and industry. }\end{array}$ & $\begin{array}{l}\text { NIST Manufac- } \\
\text { turing Collabo- } \\
\text { ratory (p. } 45)\end{array}$ \\
\hline Systems Modeling Corporation & $\begin{array}{l}\text { Pittsburgh, } \\
\text { PA }\end{array}$ & Vendor of scheduling and simulation software. & $\begin{array}{l}\text { Production and } \\
\text { Product Data } \\
\text { Management } \\
\text { Applications (p. } \\
\text { 29) }\end{array}$ \\
\hline TeamWave Software Ltd. & $\begin{array}{l}\text { Calgary, } \\
\text { Alberta, } \\
\text { Canada }\end{array}$ & $\begin{array}{l}\text { Vendor of software products that support distributed col- } \\
\text { laborations. }\end{array}$ & $\begin{array}{l}\text { NIST Manufac- } \\
\text { turing Collabo- } \\
\text { ratory (p. } 45 \text { ) }\end{array}$ \\
\hline
\end{tabular}




\begin{tabular}{|c|c|c|c|}
\hline \multicolumn{4}{|c|}{ Individual Companies } \\
\hline Name & Location & Description & $\begin{array}{l}\text { Collaborating } \\
\text { Project(s) }\end{array}$ \\
\hline Texas Instruments & Dallas, TX & Electronics manufacturer. & $\begin{array}{l}\text { Electronic Com- } \\
\text { merce for the } \\
\text { Electronics } \\
\text { Industry (ECEI) } \\
\text { (p. 17) } \\
\text { Information } \\
\text { Exchange Proto- } \\
\text { cols for Design } \\
\text { (p. 20) }\end{array}$ \\
\hline TechnoSoft, Inc. & $\begin{array}{l}\text { Cincinnati, } \\
\mathrm{OH}\end{array}$ & Software vendor. & $\begin{array}{l}\text { Information } \\
\text { Exchange Proto- } \\
\text { cols for Design } \\
\text { (p. 20) }\end{array}$ \\
\hline Transom Technologies & $\begin{array}{l}\text { Ann Arbor, } \\
\text { MI }\end{array}$ & A provider of human modeling and simulation software. & $\begin{array}{l}\text { Virtual Environ- } \\
\text { ments and Visu- } \\
\text { alization for } \\
\text { Manufacturing } \\
\text { (p. 36) }\end{array}$ \\
\hline Veo Systems, Inc. & $\begin{array}{l}\text { Mountain } \\
\text { View, CA }\end{array}$ & $\begin{array}{l}\text { A supplier of products and services to enable open com- } \\
\text { merce networks. }\end{array}$ & $\begin{array}{l}\text { Internet Com- } \\
\text { merce for Man- } \\
\text { ufacturing (p. } \\
22 \text { ) }\end{array}$ \\
\hline $\begin{array}{l}\text { Viewlogic Systems Incorpo- } \\
\text { rated }\end{array}$ & $\begin{array}{l}\text { Marlbor- } \\
\text { ough, MA }\end{array}$ & $\begin{array}{l}\text { Vendor of electronic product design and engineering } \\
\text { software. }\end{array}$ & $\begin{array}{l}\text { Electronic Com- } \\
\text { merce for the } \\
\text { Electronics } \\
\text { Industry (ECEI) } \\
\text { (p. 17) }\end{array}$ \\
\hline Wonderware, Inc. & Irving, CA & Vendor of shop floor data collection software. & $\begin{array}{l}\text { Production and } \\
\text { Product Data } \\
\text { Management } \\
\text { Applications (p. } \\
29 \text { ) }\end{array}$ \\
\hline Xerox Corporation & $\begin{array}{l}\text { Stamford, } \\
\text { CT }\end{array}$ & Large document and document technology company. & $\begin{array}{l}\text { Information } \\
\text { Exchange Proto- } \\
\text { cols for Design } \\
\text { (p. 20) }\end{array}$ \\
\hline
\end{tabular}




\begin{tabular}{|c|c|c|c|}
\hline \multicolumn{4}{|c|}{ Government Agencies } \\
\hline Name & Location & Description & $\begin{array}{l}\text { Collaborating } \\
\text { Project(s) }\end{array}$ \\
\hline $\begin{array}{l}\text { Consumer Product Safety } \\
\text { Commission }\end{array}$ & $\begin{array}{l}\text { Washing- } \\
\text { ton, DC }\end{array}$ & $\begin{array}{l}\text { An independent federal regulatory agency charged to } \\
\text { "protect the public against unreasonable risks of injuries } \\
\text { and deaths associated with consumer products." }\end{array}$ & $\begin{array}{l}\text { Virtual Environ- } \\
\text { ments and Visu- } \\
\text { alization for } \\
\text { Manufacturing } \\
\text { (p. 36) }\end{array}$ \\
\hline $\begin{array}{l}\text { Defense Advanced Research } \\
\text { Projects Agency (DARPA) }\end{array}$ & $\begin{array}{l}\text { Arlington, } \\
\text { VA }\end{array}$ & $\begin{array}{l}\text { This Defense Department agency's primary mission is to } \\
\text { develop imaginative, innovative and often high risk } \\
\text { research ideas offering a significant technological impact } \\
\text { that will go well beyond the normal evolutionary devel- } \\
\text { opmental approaches; and, to pursue these ideas from } \\
\text { the demonstration of technical feasibility through the } \\
\text { development of prototype systems. }\end{array}$ & $\begin{array}{l}\text { Enterprise } \\
\text { Resource Plan- } \\
\text { ning Interfaces } \\
\text { (ERP-I) (p. 19) } \\
\text { Information } \\
\text { Exchange Proto- } \\
\text { cols for Design } \\
\text { (p. 20) } \\
\text { Internet Com- } \\
\text { merce for Man- } \\
\text { ufacturing (p. } \\
\text { 22) }\end{array}$ \\
\hline $\begin{array}{l}\text { Los Alamos National Labora- } \\
\text { tory }\end{array}$ & $\begin{array}{l}\text { Los Ala- } \\
\text { mos, NM }\end{array}$ & $\begin{array}{l}\text { The Laboratory's central mission is reducing the danger } \\
\text { of nuclear weapons and nuclear materials worldwide. Its } \\
\text { statutory responsibility is the stewardship and manage- } \\
\text { ment of the nuclear stockpile. Work for this project } \\
\text { involves development of a Laboratory Equipment Con- } \\
\text { trol Interface (LECI) specification. }\end{array}$ & $\begin{array}{l}\text { Standards for } \\
\text { Exchange of } \\
\text { Instrument Data } \\
\text { and NIST } \\
\text { Chemical Refer- } \\
\text { ence Data (p. } \\
\text { 43) }\end{array}$ \\
\hline $\begin{array}{l}\text { Max-Planck Gesellschaft zur } \\
\text { Förderung der Wissenschaften } \\
\text { e.V. }\end{array}$ & $\begin{array}{l}\text { Munich, } \\
\text { Germany }\end{array}$ & $\begin{array}{l}\text { Max Planck Institutes carry on basic research in service } \\
\text { to the general public in the areas of natural science, } \\
\text { social science, and the arts and humanities. In particular, } \\
\text { the Max Planck Society takes up new and promising } \\
\text { directions in research that universities are unable to } \\
\text { accommodate sufficiently, if at all. }\end{array}$ & $\begin{array}{l}\text { Computerized } \\
\text { Access to Full } \\
\text { Structural Crys- } \\
\text { tallographic } \\
\text { Data (p. 40) }\end{array}$ \\
\hline Naval Research Laboratory & $\begin{array}{l}\text { Washing- } \\
\text { ton, DC }\end{array}$ & $\begin{array}{l}\text { As the Navy's corporate laboratory, NRL conducts a } \\
\text { broadly-based multidisciplinary program of scientific } \\
\text { research and advanced technological development } \\
\text { directed toward maritime applications of new and } \\
\text { improved materials, techniques, equipment, system, and } \\
\text { ocean, atmospheric, and space sciences and related tech- } \\
\text { nologies. }\end{array}$ & $\begin{array}{l}\text { Electronic Com- } \\
\text { merce for the } \\
\text { Electronics } \\
\text { Industry (ECEI) } \\
\text { (p. 17) }\end{array}$ \\
\hline $\begin{array}{l}\text { Pacific Northwest National } \\
\text { Laboratory }\end{array}$ & $\begin{array}{l}\text { Richland, } \\
\text { WA }\end{array}$ & $\begin{array}{l}\text { The Pacific Northwest National Laboratory's core mis- } \\
\text { sion is to deliver environmental science and technology. }\end{array}$ & $\begin{array}{l}\text { Online Access } \\
\text { to NIST Chemi- } \\
\text { cal Reference } \\
\text { Data (p. 42) }\end{array}$ \\
\hline
\end{tabular}




\begin{tabular}{|c|c|c|c|}
\hline \multicolumn{4}{|c|}{ Government Agencies } \\
\hline Name & Location & Description & $\begin{array}{l}\text { Collaborating } \\
\text { Project(s) }\end{array}$ \\
\hline TACOM & Warren, MI & $\begin{array}{l}\text { Mission is to research, develop, field and support mobil- } \\
\text { ity, armament, munitions, and chemical systems and } \\
\text { materiels through their total life cycle. }\end{array}$ & $\begin{array}{l}\text { STEP Conform- } \\
\text { ance and } \\
\text { Interoperability } \\
\text { Testing (p. 33) }\end{array}$ \\
\hline $\begin{array}{l}\text { US Army, Tobyhanna Army } \\
\text { Depot }\end{array}$ & $\begin{array}{l}\text { Toby- } \\
\text { hanna, PA }\end{array}$ & $\begin{array}{l}\text { Communications and electronic equipment repair, over- } \\
\text { haul, and fabrication facility. }\end{array}$ & $\begin{array}{l}\text { Application Pro- } \\
\text { tocol Develop- } \\
\text { ment } \\
\text { Environment } \\
\text { (APDE) (p. 14) }\end{array}$ \\
\hline
\end{tabular}

\begin{tabular}{|c|c|c|c|}
\hline \multicolumn{4}{|c|}{ Academic Institutions } \\
\hline Name & Location & Department & $\begin{array}{l}\text { Collaborating } \\
\text { Project(s) }\end{array}$ \\
\hline Arizona State University & Tempe, AZ & $\begin{array}{l}\text { Department of Industrial \& Manufacturing Systems } \\
\text { Engineering }\end{array}$ & $\begin{array}{l}\text { Production and } \\
\text { Product Data } \\
\text { Management } \\
\text { Applications (p. } \\
\text { 29) } \\
\text { Analysis Tools } \\
\text { for Assessment } \\
\text { and Optimiza- } \\
\text { tion of Process } \\
\text { and Product } \\
\text { Design (p. 37) }\end{array}$ \\
\hline Catholic University & $\begin{array}{l}\text { Washing- } \\
\text { ton, DC }\end{array}$ & Department of Mechanical Engineering & $\begin{array}{l}\text { Reference } \\
\text { Model Architec- } \\
\text { ture (p. 31) }\end{array}$ \\
\hline Colorado School of Mines & $\begin{array}{l}\text { Golden, } \\
\mathrm{CO}\end{array}$ & Division of Engineering & $\begin{array}{l}\text { Green's Func- } \\
\text { tion Library for } \\
\text { Advanced Mate- } \\
\text { rials Applica- } \\
\text { tions with Web } \\
\text { Access (p. } 41)\end{array}$ \\
\hline Drexel University & $\begin{array}{l}\text { Philadel- } \\
\text { phia, PA }\end{array}$ & Department of Electrical and Computer Engineering & $\begin{array}{l}\text { Reference } \\
\text { Model Architec- } \\
\text { ture (p. 31) }\end{array}$ \\
\hline $\begin{array}{l}\text { Eindhoven University of Tech- } \\
\text { nology }\end{array}$ & $\begin{array}{l}\text { Eind- } \\
\text { hoven, The } \\
\text { Nether- } \\
\text { lands }\end{array}$ & Department of Technology Management & $\begin{array}{l}\text { Production and } \\
\text { Product Data } \\
\text { Management } \\
\text { Applications (p. } \\
\text { 29) }\end{array}$ \\
\hline
\end{tabular}




\section{Collaborators}

\begin{tabular}{|c|c|c|c|}
\hline \multicolumn{4}{|c|}{ Academic Institutions } \\
\hline Name & Location & Department & $\begin{array}{l}\text { Collaborating } \\
\text { Project(s) }\end{array}$ \\
\hline Fachhochschule Wiesbaden & $\begin{array}{l}\text { Weis- } \\
\text { baden, } \\
\text { Germany }\end{array}$ & Computer Science Department & $\begin{array}{l}\text { Standards for } \\
\text { Exchange of } \\
\text { Instrument Data } \\
\text { and NIST } \\
\text { Chemical Refer- } \\
\text { ence Data (p. } \\
\text { 43) }\end{array}$ \\
\hline George Washington University & $\begin{array}{l}\text { Washing- } \\
\text { ton, DC }\end{array}$ & Department of Engineering Management & $\begin{array}{l}\text { Information } \\
\text { Exchange Proto- } \\
\text { cols for Design } \\
\text { (p. 20) } \\
\text { Process Specifi- } \\
\text { cation Lan- } \\
\text { guage (p. 27) }\end{array}$ \\
\hline $\begin{array}{l}\text { Georgia Institute of Technol- } \\
\text { ogy (Georgia Tech) }\end{array}$ & $\begin{array}{l}\text { Atlanta, } \\
\text { Georgia }\end{array}$ & Manufacturing Research Center & $\begin{array}{l}\text { Electronic Com- } \\
\text { merce for the } \\
\text { Electronics } \\
\text { Industry (ECEI) } \\
\text { (p. 17) } \\
\text { Internet Com- } \\
\text { merce for Man- } \\
\text { ufacturing (p. } \\
22 \text { ) }\end{array}$ \\
\hline Harvard University & $\begin{array}{l}\text { Cam- } \\
\text { bridge, MA }\end{array}$ & Harvard Smithsonian Center for Astrophysics & $\begin{array}{l}\text { Integration of } \\
\text { NIST Standard } \\
\text { Reference Data } \\
\text { into Informa- } \\
\text { tion Networks } \\
\text { (p. 41) }\end{array}$ \\
\hline $\begin{array}{l}\text { Indian Institute of Management } \\
\text { Bangalore }\end{array}$ & $\begin{array}{l}\text { Bangalore, } \\
\text { India }\end{array}$ & $\begin{array}{l}\text { Specializes in the field of management education for the } \\
\text { highly competitive and varied businesses of the future. }\end{array}$ & $\begin{array}{l}\text { Enterprise } \\
\text { Resource Plan- } \\
\text { ning Interfaces } \\
(\text { ERP-I) (p. 19) }\end{array}$ \\
\hline $\begin{array}{l}\text { Institut Français de Mécanique } \\
\text { Avancée }\end{array}$ & $\begin{array}{l}\text { Aubiere, } \\
\text { France }\end{array}$ & Advanced Production Systems & $\begin{array}{l}\text { Production and } \\
\text { Product Data } \\
\text { Management } \\
\text { Applications (p. } \\
\text { 29) }\end{array}$ \\
\hline Iowa State University & $\begin{array}{l}\text { Ames, } \\
\text { Iowa }\end{array}$ & $\begin{array}{l}\text { Department of Aerospace Engineering and Engineering } \\
\text { Mechanics }\end{array}$ & $\begin{array}{l}\text { Green's Func- } \\
\text { tion Library for } \\
\text { Advanced Mate- } \\
\text { rials Applica- } \\
\text { tions with Web } \\
\text { Access (p. } 41 \text { ) }\end{array}$ \\
\hline Long Island University & $\begin{array}{l}\text { Brooklyn, } \\
\text { NY }\end{array}$ & Department of Chemistry & $\begin{array}{l}\text { Online Access } \\
\text { to NIST Chemi- } \\
\text { cal Reference } \\
\text { Data (p. 42) }\end{array}$ \\
\hline
\end{tabular}




\begin{tabular}{|c|c|c|c|}
\hline \multicolumn{4}{|c|}{ Academic Institutions } \\
\hline Name & Location & Department & $\begin{array}{l}\text { Collaborating } \\
\text { Project(s) }\end{array}$ \\
\hline $\begin{array}{l}\text { Michigan Technological Uni- } \\
\text { versity }\end{array}$ & $\begin{array}{l}\text { Houghton, } \\
\text { MI }\end{array}$ & Department of Mechanical Engineering & $\begin{array}{l}\text { Production and } \\
\text { Product Data } \\
\text { Management } \\
\text { Applications (p. } \\
\text { 29) }\end{array}$ \\
\hline Musashi University & $\begin{array}{l}\text { Tokyo, } \\
\text { Japan }\end{array}$ & Department of Management & $\begin{array}{l}\text { Production and } \\
\text { Product Data } \\
\text { Management } \\
\text { Applications (p. } \\
29 \text { ) }\end{array}$ \\
\hline Ohio University & $\begin{array}{l}\text { Athens, } \\
\mathrm{OH}\end{array}$ & Department of Industrial and Systems Engineering & $\begin{array}{l}\text { Production and } \\
\text { Product Data } \\
\text { Management } \\
\text { Applications (p. } \\
\text { 29) }\end{array}$ \\
\hline Pennsylvania State University & $\begin{array}{l}\text { State Col- } \\
\text { lege, PA }\end{array}$ & Industrial and Manufacturing Engineering Department & $\begin{array}{l}\text { Production and } \\
\text { Product Data } \\
\text { Management } \\
\text { Applications (p. } \\
\text { 29) }\end{array}$ \\
\hline Politechno di Milano & $\begin{array}{l}\text { Milano, } \\
\text { Italy }\end{array}$ & Diportimento di Economia e Produzione & $\begin{array}{l}\text { Production and } \\
\text { Product Data } \\
\text { Management } \\
\text { Applications (p. } \\
29 \text { ) }\end{array}$ \\
\hline $\begin{array}{l}\text { Robert Wood Johnson Medical } \\
\text { School }\end{array}$ & $\begin{array}{l}\text { New Brun- } \\
\text { swick, NJ }\end{array}$ & Department of Pharmacology & $\begin{array}{l}\text { Web-Based Bio- } \\
\text { informatics } \\
\text { Databases (p. } \\
43 \text { ) }\end{array}$ \\
\hline Rutgers University & $\begin{array}{l}\text { New Brun- } \\
\text { swick, NJ }\end{array}$ & Department of Chemistry & $\begin{array}{l}\text { Web-Based Bio- } \\
\text { informatics } \\
\text { Databases (p. } \\
43 \text { ) }\end{array}$ \\
\hline Stanford University & $\begin{array}{l}\text { Palo Alto, } \\
\text { CA }\end{array}$ & Computer Science Department & $\begin{array}{l}\text { Information } \\
\text { Exchange Proto- } \\
\text { cols for Design } \\
\text { (p. 20) }\end{array}$ \\
\hline State University of New York & $\begin{array}{l}\text { Bingham- } \\
\text { ton, NY }\end{array}$ & $\begin{array}{l}\text { Department of Systems, Sciences, and Industrial Engi- } \\
\text { neering }\end{array}$ & $\begin{array}{l}\text { Internet Com- } \\
\text { merce for Man- } \\
\text { ufacturing (p. } \\
22 \text { ) }\end{array}$ \\
\hline Syracuse University & $\begin{array}{l}\text { Syracuse, } \\
\text { NY }\end{array}$ & $\begin{array}{l}\text { Department of Mechanical, Aerospace, and Manufactur- } \\
\text { ing Engineering }\end{array}$ & $\begin{array}{l}\text { Information } \\
\text { Exchange Proto- } \\
\text { cols for Design } \\
\text { (p. 20) }\end{array}$ \\
\hline
\end{tabular}




\section{Collaborators}

\begin{tabular}{|c|c|c|c|}
\hline \multicolumn{4}{|c|}{ Academic Institutions } \\
\hline Name & Location & Department & $\begin{array}{l}\text { Collaborating } \\
\text { Project(s) }\end{array}$ \\
\hline Université de Nancy & $\begin{array}{l}\text { Nancy, } \\
\text { France }\end{array}$ & $\begin{array}{l}\text { École Supérieure d'Informatique et Applications de Lor- } \\
\text { raine }\end{array}$ & $\begin{array}{l}\text { Production and } \\
\text { Product Data } \\
\text { Management } \\
\text { Applications (p. } \\
\text { 29) }\end{array}$ \\
\hline University of Canterbury & $\begin{array}{l}\text { Christ- } \\
\text { church, NZ }\end{array}$ & Department of Chemistry & $\begin{array}{l}\text { Online Access } \\
\text { to NIST Chemi- } \\
\text { cal Reference } \\
\text { Data (p. 42) }\end{array}$ \\
\hline University of California & $\begin{array}{l}\text { San Diego, } \\
\text { CA }\end{array}$ & San Diego Supercomputer Center & $\begin{array}{l}\text { Web-Based Bio- } \\
\text { informatics } \\
\text { Databases (p. } \\
43 \text { ) }\end{array}$ \\
\hline University of Cincinnati & $\begin{array}{l}\text { Cincinnati, } \\
\mathrm{OH}\end{array}$ & $\begin{array}{l}\text { Department of Electrical and Computer Engineering and } \\
\text { Computer Science }\end{array}$ & $\begin{array}{l}\text { Framework (p. } \\
24)\end{array}$ \\
\hline University of Darmstadt & $\begin{array}{l}\text { Darmstadt, } \\
\text { Germany }\end{array}$ & Industrial Applications Department & $\begin{array}{l}\text { Application Pro- } \\
\text { tocol Develop- } \\
\text { ment } \\
\text { Environment } \\
\text { (APDE) (p. 14) }\end{array}$ \\
\hline University of Edinburgh & $\begin{array}{l}\text { Edinburgh, } \\
\text { UK }\end{array}$ & Artificial Intelligence Application Institute & $\begin{array}{l}\text { Process Specifi- } \\
\text { cation Lan- } \\
\text { guage (p. 27) }\end{array}$ \\
\hline University of Illinois & $\begin{array}{l}\text { Chicago, } \\
\text { IL }\end{array}$ & Department of Computer Science & $\begin{array}{l}\text { Operator Inter- } \\
\text { faces for Virtual } \\
\text { and Distributed } \\
\text { Manufacturing } \\
\text { (p. 26) }\end{array}$ \\
\hline University of Illinois & $\begin{array}{l}\text { Chicago, } \\
\text { IL }\end{array}$ & Department of Mechanical Engineering & $\begin{array}{l}\text { Production and } \\
\text { Product Data } \\
\text { Management } \\
\text { Applications (p. } \\
\text { 29) } \\
\text { Virtual Environ- } \\
\text { ments and Visu- } \\
\text { alization for } \\
\text { Manufacturing } \\
\text { (p. 36) }\end{array}$ \\
\hline $\begin{array}{l}\text { University of Illinois at } \\
\text { Urbana-Champaign }\end{array}$ & Urbana, IL & Department of General Engineering & $\begin{array}{l}\text { Reference } \\
\text { Model Architec- } \\
\text { ture (p. 31) }\end{array}$ \\
\hline
\end{tabular}




\begin{tabular}{|c|c|c|c|}
\hline \multicolumn{4}{|c|}{ Academic Institutions } \\
\hline Name & Location & Department & $\begin{array}{l}\text { Collaborating } \\
\text { Project(s) }\end{array}$ \\
\hline University of Maryland & $\begin{array}{l}\text { College } \\
\text { Park, MD }\end{array}$ & Department of Computer Science & $\begin{array}{l}\text { Information } \\
\text { Exchange Proto- } \\
\text { cols for Design } \\
\text { (p. 20) } \\
\text { Process Specifi- } \\
\text { cation Lan- } \\
\text { guage (p. 27) } \\
\text { Production and } \\
\text { Product Data } \\
\text { Management } \\
\text { Applications (p. } \\
\text { 29) }\end{array}$ \\
\hline University of Maryland & $\begin{array}{l}\text { College } \\
\text { Park, MD }\end{array}$ & Department of Electrical Engineering & $\begin{array}{l}\text { Reference } \\
\text { Model Architec- } \\
\text { ture (p. 31) }\end{array}$ \\
\hline University of Maryland & $\begin{array}{l}\text { College } \\
\text { Park, MD }\end{array}$ & Department of Mechanical Engineering & $\begin{array}{l}\text { Process Specifi- } \\
\text { cation Lan- } \\
\text { guage (p. 27) } \\
\text { Design - Process } \\
\text { Planning Inte- } \\
\text { gration (DPPI) } \\
\text { (p. 16) }\end{array}$ \\
\hline $\begin{array}{l}\text { University of Maryland - Balti- } \\
\text { more County }\end{array}$ & $\begin{array}{l}\text { Catons- } \\
\text { ville, MD }\end{array}$ & Department of Chemistry & $\begin{array}{l}\text { Online Access } \\
\text { to NIST Chemi- } \\
\text { cal Reference } \\
\text { Data (p. 42) }\end{array}$ \\
\hline University of Melbourne & $\begin{array}{l}\text { Parkville, } \\
\text { Victoria, } \\
\text { Australia }\end{array}$ & School of Physics & $\begin{array}{l}\text { Integration of } \\
\text { NIST Standard } \\
\text { Reference Data } \\
\text { into Informa- } \\
\text { tion Networks } \\
\text { (p. 41) }\end{array}$ \\
\hline University of Michigan & $\begin{array}{l}\text { Ann Arbor, } \\
\text { MI }\end{array}$ & $\begin{array}{l}\text { School of Information } \\
\text { Collaboratory for Research in Electronic Work (CREW) }\end{array}$ & $\begin{array}{l}\text { NIST Manufac- } \\
\text { turing Collabo- } \\
\text { ratory (p. 45) }\end{array}$ \\
\hline University of Michigan & $\begin{array}{l}\text { Ann Arbor, } \\
\text { MI }\end{array}$ & $\begin{array}{l}\text { Electrical Engineering and Computer Science Depart- } \\
\text { ment }\end{array}$ & $\begin{array}{l}\text { Information } \\
\text { Exchange Proto- } \\
\text { cols for Design } \\
\text { (p. 20) }\end{array}$ \\
\hline University of New Brunswick & $\begin{array}{l}\text { Saint John, } \\
\text { NB, Can- } \\
\text { ada }\end{array}$ & Department of Physical Sciences & $\begin{array}{l}\text { Integration of } \\
\text { NIST Standard } \\
\text { Reference Data } \\
\text { into Informa- } \\
\text { tion Networks } \\
\text { (p. 41) }\end{array}$ \\
\hline
\end{tabular}




\section{Collaborators}

\begin{tabular}{|c|c|c|c|}
\hline \multicolumn{4}{|c|}{ Academic Institutions } \\
\hline Name & Location & Department & $\begin{array}{l}\text { Collaborating } \\
\text { Project(s) }\end{array}$ \\
\hline University of Pennsylvania & $\begin{array}{l}\text { Philadel- } \\
\text { phia, PA }\end{array}$ & Center for Human Modeling and Simulation & $\begin{array}{l}\text { Virtual Environ- } \\
\text { ments and Visu- } \\
\text { alization for } \\
\text { Manufacturing } \\
\text { (p. 36) }\end{array}$ \\
\hline University of Pittsburgh & $\begin{array}{l}\text { Pittsburgh, } \\
\text { PA }\end{array}$ & Department of Chemistry & $\begin{array}{l}\text { Web-Based Bio- } \\
\text { informatics } \\
\text { Databases (p. } \\
43 \text { ) }\end{array}$ \\
\hline University of Rochester & $\begin{array}{l}\text { Rochester, } \\
\text { NY }\end{array}$ & Department of Mathematics & $\begin{array}{l}\text { Information } \\
\text { Exchange Proto- } \\
\text { cols for Design } \\
\text { (p. 20) }\end{array}$ \\
\hline University of Tennessee & $\begin{array}{l}\text { Knoxville, } \\
\text { TN }\end{array}$ & Department of Chemistry & $\begin{array}{l}\text { Online Access } \\
\text { to NIST Chemi- } \\
\text { cal Reference } \\
\text { Data (p. } 42 \text { ) }\end{array}$ \\
\hline University of Texas & $\begin{array}{l}\text { Arlington, } \\
\text { TX }\end{array}$ & $\begin{array}{l}\text { Department of Industrial \& Manufacturing Systems } \\
\text { Engineering }\end{array}$ & $\begin{array}{l}\text { Analysis Tools } \\
\text { for Assessment } \\
\text { and Optimiza- } \\
\text { tion of Process } \\
\text { and Product } \\
\text { Design (p. 37) }\end{array}$ \\
\hline University of Toronto & $\begin{array}{l}\text { Toronto, } \\
\text { Canada }\end{array}$ & Enterprise Integration Laboratory & $\begin{array}{l}\text { Process Specifi- } \\
\text { cation Lan- } \\
\text { guage (p. } 27 \text { ) }\end{array}$ \\
\hline Virginia Polytechnic University & $\begin{array}{l}\text { Blacks- } \\
\text { burg, VA }\end{array}$ & Department of Industrial and Systems Engineering & $\begin{array}{l}\text { Production and } \\
\text { Product Data } \\
\text { Management } \\
\text { Applications (p. } \\
\text { 29) }\end{array}$ \\
\hline Washington State University & $\begin{array}{l}\text { Pullman, } \\
\text { WA }\end{array}$ & School of Mechanical and Materials Engineering & $\begin{array}{l}\text { Information } \\
\text { Exchange Proto- } \\
\text { cols for Design } \\
\text { (p. 20) }\end{array}$ \\
\hline Wayne State University & Detroit, MI & Industrial and Manufacturing Engineering Department & $\begin{array}{l}\text { STEP Conform- } \\
\text { ance and } \\
\text { Interoperability } \\
\text { Testing (p. 33) }\end{array}$ \\
\hline
\end{tabular}




\begin{tabular}{|c|c|c|c|}
\hline \multicolumn{4}{|c|}{ Standards Committees } \\
\hline Committee & Organization & Description & $\begin{array}{l}\text { Collaborating } \\
\text { Project(s) }\end{array}$ \\
\hline $\begin{array}{l}\text { ASTM/SC } \\
\text { E49.08 }\end{array}$ & $\begin{array}{l}\text { American Society for Testing } \\
\text { and Materials }\end{array}$ & Analytical Data Interchange Protocols. & $\begin{array}{l}\text { Standards for } \\
\text { Exchange of } \\
\text { Instrument Data } \\
\text { and NIST } \\
\text { Chemical Refer- } \\
\text { ence Data (p. } \\
\text { 43) }\end{array}$ \\
\hline $\begin{array}{l}\text { ASTM/SC } \\
\text { E49.52 }\end{array}$ & $\begin{array}{l}\text { American Society for Testing } \\
\text { and Materials }\end{array}$ & Computerization of Analytical Sciences Data. & $\begin{array}{l}\text { Standards for } \\
\text { Exchange of } \\
\text { Instrument Data } \\
\text { and NIST } \\
\text { Chemical Refer- } \\
\text { ence Data (p. } \\
\text { 43) }\end{array}$ \\
\hline DATC/ECCI & $\begin{array}{l}\text { Institute of Electrical and Elec- } \\
\text { tronics Engineers (IEEE) }\end{array}$ & $\begin{array}{l}\text { Professional society for advancing the theory and } \\
\text { practice of electrical, electronics and computer } \\
\text { engineering and computer science. }\end{array}$ & $\begin{array}{l}\text { Electronic Com- } \\
\text { merce for the } \\
\text { Electronics } \\
\text { Industry (ECEI) } \\
\text { (p. 17) }\end{array}$ \\
\hline IEC/TC3/SC3D & $\begin{array}{l}\text { International Electrotechnical } \\
\text { Commission (IEC) }\end{array}$ & $\begin{array}{l}\text { The role of IEC/TC3/SC3D is to prepare standards } \\
\text { regarding methods and rules associated with the } \\
\text { handling of information in computer-sensible form. } \\
\text { This includes definition of data element types and } \\
\text { data sets for use in information models and techni- } \\
\text { cal documentation, and for exchange of technical } \\
\text { information. }\end{array}$ & $\begin{array}{l}\text { Electronic Com- } \\
\text { merce for the } \\
\text { Electronics } \\
\text { Industry (ECEI) } \\
\text { (p. 17) }\end{array}$ \\
\hline IEC/TC93/WG1 & $\begin{array}{l}\text { International Electrotechnical } \\
\text { Commission (IEC) }\end{array}$ & $\begin{array}{l}\text { The role of IEC/TC93/WG1 is to propose to TC } 93 \\
\text { an overall strategy and practical working approach } \\
\text { for the harmonization and interoperability of elec- } \\
\text { trotechnical data description standards. }\end{array}$ & $\begin{array}{l}\text { Electronic Com- } \\
\text { merce for the } \\
\text { Electronics } \\
\text { Industry (ECEI) } \\
\text { (p. 17) }\end{array}$ \\
\hline IEC/TC93/WG2 & $\begin{array}{l}\text { International Electrotechnical } \\
\text { Commission (IEC) }\end{array}$ & $\begin{array}{l}\text { The role of IEC/TC93/WG2 is to review the techni- } \\
\text { cal quality of hardware description language } \\
\text { (HDL)-related draft standards developed by work- } \\
\text { ing groups of other standards group, the harmoniza- } \\
\text { tion of HDL-related work done in other standards } \\
\text { groups, and to make recommendations to allied } \\
\text { standards groups such as the IEEE and EIAJ for } \\
\text { development of new standards. }\end{array}$ & $\begin{array}{l}\text { Electronic Com- } \\
\text { merce for the } \\
\text { Electronics } \\
\text { Industry (ECEI) } \\
\text { (p. 17) }\end{array}$ \\
\hline IEC/TC93/WG3 & $\begin{array}{l}\text { International Electrotechnical } \\
\text { Commission (IEC) }\end{array}$ & $\begin{array}{l}\text { The role of IEC/TC93/WG3 is to develop an IEC } \\
\text { Standard based on the EDIF Standard from the EIA } \\
\text { (Electronic Industries Association) in the U.S. The } \\
\text { coverage of this standard includes an exchange for- } \\
\text { mat for describing the connectivity of components } \\
\text { in electronic and electrotechnical netlists and PC } \\
\text { boards. }\end{array}$ & $\begin{array}{l}\text { Electronic Com- } \\
\text { merce for the } \\
\text { Electronics } \\
\text { Industry (ECEI) } \\
\text { (p. 17) }\end{array}$ \\
\hline
\end{tabular}




\section{Collaborators}

\begin{tabular}{|c|c|c|c|}
\hline \multicolumn{4}{|c|}{ Standards Committees } \\
\hline Committee & Organization & Description & $\begin{array}{l}\text { Collaborating } \\
\text { Project(s) }\end{array}$ \\
\hline IEC/TC93/WG5 & $\begin{array}{l}\text { International Electrotechnical } \\
\text { Commission (IEC) }\end{array}$ & $\begin{array}{l}\text { The role of IEC/TC93/WG5 is to investigate test, } \\
\text { validation, conformance and qualification method- } \\
\text { ologies for international standards for electrical and } \\
\text { electronic product data exchange. }\end{array}$ & $\begin{array}{l}\text { Electronic Com- } \\
\text { merce for the } \\
\text { Electronics } \\
\text { Industry (ECEI) } \\
\text { (p. 17) }\end{array}$ \\
\hline $\begin{array}{l}\text { Area Commit- } \\
\text { tee: Automation }\end{array}$ & $\begin{array}{l}\text { National Committee for Clini- } \\
\text { cal Laboratory Standards }\end{array}$ & $\begin{array}{l}\text { Subcommittee: System Status and Error and Excep- } \\
\text { tion Handling. }\end{array}$ & $\begin{array}{l}\text { Standards for } \\
\text { Exchange of } \\
\text { Instrument Data } \\
\text { and NIST } \\
\text { Chemical Refer- } \\
\text { ence Data (p. } \\
\text { 43) }\end{array}$ \\
\hline $\begin{array}{l}\text { Area Commit- } \\
\text { tee: Automation }\end{array}$ & $\begin{array}{l}\text { National Committee for Clini- } \\
\text { cal Laboratory Standards }\end{array}$ & $\begin{array}{l}\text { Subcommittee: Communications with Automated } \\
\text { Systems. }\end{array}$ & $\begin{array}{l}\text { Standards for } \\
\text { Exchange of } \\
\text { Instrument Data } \\
\text { and NIST } \\
\text { Chemical Refer- } \\
\text { ence Data (p. } \\
\text { 43) }\end{array}$ \\
\hline TC29/WG34 & $\begin{array}{l}\text { International Organization for } \\
\text { Standardization (ISO) }\end{array}$ & $\begin{array}{l}\text { Technical Committee: Small Tools. } \\
\text { Working Group: Carbide Cutting Tools. }\end{array}$ & $\begin{array}{l}\text { Information } \\
\text { Exchange Proto- } \\
\text { cols for Design } \\
\text { (p. 20) }\end{array}$ \\
\hline TC184/SC4 & $\begin{array}{l}\text { International Organization for } \\
\text { Standardization (ISO) }\end{array}$ & $\begin{array}{l}\text { Technical Committee: Industrial Automation Sys- } \\
\text { tems and Integration. } \\
\text { Subcommittee: Industrial Data. } \\
\text { SC4 develops standards that provide capabilities to } \\
\text { describe and manage product data throughout the } \\
\text { life of the product. }\end{array}$ & $\begin{array}{l}\text { Application Pro- } \\
\text { tocol Develop- } \\
\text { ment } \\
\text { Environment } \\
\text { (APDE) (p. 14) }\end{array}$ \\
\hline $\begin{array}{l}\text { TC184/SC4/ } \\
\text { Quality Com- } \\
\text { mittee }\end{array}$ & $\begin{array}{l}\text { International Organization for } \\
\text { Standardization (ISO) }\end{array}$ & $\begin{array}{l}\text { Responsible for developing STEP methods and } \\
\text { assessing the compliance of draft STEP parts with } \\
\text { prescribed methods. }\end{array}$ & $\begin{array}{l}\text { STEP Conform- } \\
\text { ance and } \\
\text { Interoperability } \\
\text { Testing (p. 33) }\end{array}$ \\
\hline $\begin{array}{l}\text { TC184/SC4/ } \\
\text { WG3/ Ad Hoc } \\
\text { Committee on } \\
\text { Parametrics }\end{array}$ & $\begin{array}{l}\text { International Organization for } \\
\text { Standardization (ISO) }\end{array}$ & $\begin{array}{l}\text { The role of the Parametrics Committee is to deter- } \\
\text { mine the need for parametric representations in } \\
\text { STEP and related standards, and propose how tech- } \\
\text { niques and models may be changed to meet those } \\
\text { needs. }\end{array}$ & $\begin{array}{l}\text { Information } \\
\text { Exchange Proto- } \\
\text { cols for Design } \\
\text { (p. 20) } \\
\text { Reference } \\
\text { Model Architec- } \\
\text { ture (p. } 31)\end{array}$ \\
\hline $\begin{array}{l}\text { TC184/SC4/ } \\
\text { WG3/T7 }\end{array}$ & $\begin{array}{l}\text { International Organization for } \\
\text { Standardization (ISO) }\end{array}$ & $\begin{array}{l}\text { Technical Committee: Industrial Automation Sys- } \\
\text { tems and Integration. } \\
\text { Subcommittee: Industrial Data. } \\
\text { Working Group: Product Modeling. } \\
\text { Team: Mechanical Product Definition. }\end{array}$ & $\begin{array}{l}\text { STEP Conform- } \\
\text { ance and } \\
\text { Interoperability } \\
\text { Testing (p. 33) } \\
\text { Reference } \\
\text { Model Architec- } \\
\text { ture (p. 31) }\end{array}$ \\
\hline
\end{tabular}




\begin{tabular}{|c|c|c|c|}
\hline \multicolumn{4}{|c|}{ Standards Committees } \\
\hline Committee & Organization & Description & $\begin{array}{l}\text { Collaborating } \\
\text { Project(s) }\end{array}$ \\
\hline $\begin{array}{l}\text { TC184/SC4/ } \\
\text { WG3/T11 }\end{array}$ & $\begin{array}{l}\text { International Organization for } \\
\text { Standardization (ISO) }\end{array}$ & $\begin{array}{l}\text { Technical Committee: Industrial Automation Sys- } \\
\text { tems and Integration. } \\
\text { Subcommittee: Industrial Data. } \\
\text { Working Group: Product Modeling. } \\
\text { Team: Manufacturing Technology. }\end{array}$ & $\begin{array}{l}\text { STEP Conform- } \\
\text { ance and } \\
\text { Interoperability } \\
\text { Testing (p. 33) } \\
\text { Reference } \\
\text { Model Architec- } \\
\text { ture (p. 31) }\end{array}$ \\
\hline $\begin{array}{l}\text { TC184/SC4/ } \\
\text { WG3/T20 }\end{array}$ & $\begin{array}{l}\text { International Organization for } \\
\text { Standardization (ISO) }\end{array}$ & $\begin{array}{l}\text { Technical Committee: Industrial Automation Sys- } \\
\text { tems and Integration. } \\
\text { Subcommittee: Industrial Data. } \\
\text { Working Group: Product Modeling. } \\
\text { Team: Process Plant Industries. }\end{array}$ & $\begin{array}{l}\text { STEP for the } \\
\text { Process Plant } \\
\text { Industries (p. } \\
\text { 35) }\end{array}$ \\
\hline $\begin{array}{l}\text { TC184/SC4/ } \\
\text { WG8 }\end{array}$ & $\begin{array}{l}\text { International Organization for } \\
\text { Standardization (ISO) }\end{array}$ & $\begin{array}{l}\text { Technical Committee: Industrial Automation Sys- } \\
\text { tems and Integration. } \\
\text { Subcommittee: Industrial Data. } \\
\text { Working Group: Industrial Manufacturing Manage- } \\
\text { ment Data. }\end{array}$ & $\begin{array}{l}\text { Enterprise } \\
\text { Resource Plan- } \\
\text { ning Interfaces } \\
\text { (ERP-I) (p. 19) }\end{array}$ \\
\hline $\begin{array}{l}\text { TC184/SC4/ } \\
\text { WG11 }\end{array}$ & $\begin{array}{l}\text { International Organization for } \\
\text { Standardization (ISO) }\end{array}$ & $\begin{array}{l}\text { Technical Committee: Industrial Automation Sys- } \\
\text { tems and Integration. } \\
\text { Subcommittee: Industrial Data. } \\
\text { Working Group: EXPRESS Language, Conform- } \\
\text { ance, Testing, and Implementation Specifications. }\end{array}$ & $\begin{array}{l}\text { STEP Conform- } \\
\text { ance and } \\
\text { Interoperability } \\
\text { Testing (p. 33) }\end{array}$ \\
\hline $\begin{array}{l}\text { TC184/SC4/ } \\
\text { JWG9 }\end{array}$ & $\begin{array}{l}\text { International Organization for } \\
\text { Standardization (ISO) }\end{array}$ & $\begin{array}{l}\text { Technical Committee: Industrial Automation Sys- } \\
\text { tems and Integration. } \\
\text { Subcommittee: Industrial Data. } \\
\text { Joint (with IEC/TC-3) Working Group: Electrical } \\
\text { Application. }\end{array}$ & $\begin{array}{l}\text { Electronic Com- } \\
\text { merce for the } \\
\text { Electronics } \\
\text { Industry (ECEI) } \\
\text { (p. } 17 \text { ) }\end{array}$ \\
\hline TC213 & $\begin{array}{l}\text { International Organization for } \\
\text { Standardization (ISO) }\end{array}$ & $\begin{array}{l}\text { Dimensional and Geometrical Product Specifica- } \\
\text { tions and Verification. }\end{array}$ & $\begin{array}{l}\text { Information } \\
\text { Exchange Proto- } \\
\text { cols for Design } \\
\text { (p. 20) }\end{array}$ \\
\hline $\begin{array}{l}\text { STEP Steering } \\
\text { Committee }\end{array}$ & $\begin{array}{l}\text { International Society for Mea- } \\
\text { surement and Control (ISA) }\end{array}$ & $\begin{array}{l}\text { Develops the ISA STEP implementation plan and } \\
\text { promotes the value of participation in the develop- } \\
\text { ment of STEP APs. }\end{array}$ & $\begin{array}{l}\text { STEP for the } \\
\text { Process Plant } \\
\text { Industries (p. } \\
\text { 35) }\end{array}$ \\
\hline
\end{tabular}




\section{Collaborators}

\begin{tabular}{|c|c|c|c|}
\hline \multicolumn{4}{|c|}{ Standards Committees } \\
\hline Committee & Organization & Description & $\begin{array}{l}\text { Collaborating } \\
\text { Project(s) }\end{array}$ \\
\hline $\begin{array}{l}\text { Manufacturing } \\
\text { Domain task } \\
\text { Force }\end{array}$ & Object Management Group & $\begin{array}{l}\text { Consortium dedicated to the development of tech- } \\
\text { nology and standards for distributed object systems. }\end{array}$ & $\begin{array}{l}\text { Enterprise } \\
\text { Resource Plan- } \\
\text { ning Interfaces } \\
\text { (ERP-I) (p. 19) } \\
\text { Production and } \\
\text { Product Data } \\
\text { Management } \\
\text { Applications (p. } \\
\text { 29) }\end{array}$ \\
\hline $\begin{array}{l}\text { OAG Integra- } \\
\text { tion Specifica- } \\
\text { tion }\end{array}$ & $\begin{array}{l}\text { Open Applications Group } \\
\text { (OAG) }\end{array}$ & $\begin{array}{l}\text { A nonprofit consortium of enterprise application } \\
\text { software developers, formed in February } 1995 \text { to } \\
\text { create common standards for the integration of } \\
\text { enterprise business applications. Member compa- } \\
\text { nies are building specifications to standardize inte- } \\
\text { gration between enterprise business applications. }\end{array}$ & $\begin{array}{l}\text { Enterprise } \\
\text { Resource Plan- } \\
\text { ning Interfaces } \\
\text { (ERP-I) (p. 19) }\end{array}$ \\
\hline
\end{tabular}




\section{Appendix C: FY97-98 Project Publications}

\section{IS1: Application Protocol Development Environment (APDE), (p. 14)}

[8] Lubell, J., "The SC4 Short Names Registry”, Sixth International EXPRESS User Group Conference, Toronto, Canada, October 1996.

Available: http://www.mel.nist.gov/msidlibrary/summary/9657.html

[9] Lubell, J., "SGML on the Web: A Tale of Two Sites", Proceedings of SGML/XML '97, Washington, DC, December 1997.

Available: http://www.mel.nist.gov/msidlibrary/summary/9755.html

[10] Lubell, J., "Structured Markup on the Web: A Tale of Two Sites", Markup Technologies: Theory and Practice, Vol 1, Issue 1-2, (to be published early 1999).

[11] Lubell, J., Phillips, L., "SGML Application Development: Tradeoffs and Choices”, SGML'96 Conference, Boston, MA, November 1996.

Available: http://www.mel.nist.gov/msidlibrary/summary/9662.html

IS2: Design - Process Planning Integration (DPPI), (p. 16)

[12] Feng, S., Qiao, L., "STEP AP213 Coverage Analysis", NISTIR 6207, NIST, Gaithersburg, MD, July 1998. Available: http://www.mel.nist.gov/msidlibrary/summary/9814.html

[13] Feng, S., Zhang, C., "A Modular Architecture for Rapid Development of CAPP Systems for Agile Manufacturing", IIE Transactions Focused Issues on Design and Manufacturing, 1997.

[14] Nederbragt, W., Allen, R., Feng, S., Kaing, S., Sriram, R., Zhang, Y., "The NIST Design/Process Planning Integration Project", Proceedings of the Artificial Intelligence and Manufacturing Research Workshop, Albuquerque, NM 1998.

Available: http://www.mel.nist.gov/msidlibrary/summary/9824.html

IS3: Electronic Commerce for the Electronics Industry (ECEI), (p. 17)

[15] McCaleb, M., "Design and Development of a Dictionary Translator", NISTIR 6219, NIST, Gaithersburg, MD, September 1998.

[16] McCaleb, M., “A Conceptual Datum Model of Datum Systems”, NIST Journal of Research, (awaiting publication), NIST, Gaithersburg, MD.

[17] Nelson, S., Parks, C., "The Model Primary Content Type for Multipurpose Internet Mail Extensions", $\underline{\text { RFC }}$ 2077, Internet Engineering Task Force, Network Working Group, January 1997

IS5: Information Exchange Protocols for Design, (p. 20)

[18] Allen, R., Sriram, R., (eds.) "Proceedings of the 1997 Knowledge-Based Interoperability Workshop", NISTIR 6111, NIST, Gaithersburg, MD, 1998.

[19] Hart, P., Lyons, K., Angster, S., Jayaram, S., "Interoperability of Assembly Analysis Applications Through the Use of the Open Assembly Design Environment", Proceedings of the ASME DETC98 Conference, Atlanta, GA, September 1998.

[20] Jayaram, S., Connacher, H., Lyons, K., "Virtual Assembly Using Virtual Reality Techniques", Computeraided Design (29)8, 1997.

[21] Lyons, K., Jayaram, S., "Simulating Physical Constraints during Virtual Assembly using Constrained Motions", Proceedings of IEEE Computer Graphics and Applications, 1997. 
[22] Lyons, K., Rajan, V., Sreerangam, R., “Assembly Representations for Capturing Mating Constraints and Component Kinematics", Proceedings of ASME Conference, Marina Del Rey, CA, August 1997.

[23] Lyons, K., Rajan, V., Sreerangam, R., "Generation of Component Degrees of Freedom from Assembly Surface Mating Constraints", Proceedings of 9th International ASME Conference on Design Theory and Methodology (DTM - 97), Sacramento, CA, September 1997.

[24] Narahari, Y., Sudarsan, R., Lyons, K., Duffey, M., Sriram, R., "Design for Tolerance of Electro-Mechanical Assemblies: An Integrated Approach”, NISTIR 6223, NIST, Gaithersburg, MD, September 1998.

Available: http://www.mel.nist.gov/msidlibrary/summary/9823.html

[25] Pratt, M., "Extension of STEP for the Representation of Parametric and Variational Models", in CAD System Development, Proceedings of the International Workshop on CAD Tools for Products, Schloss Dagstuhl, Germany, September 1995, Springer-Verlag 1997.

Available: http://www.mel.nist.gov/msidlibrary/summary/9629.html

[26] Pratt, M., Sriram, R., Wozny, M. (eds.), "Product Modelling for Computer Integrated Design and Manufacture", Proceedings of the 5th IFIP WG5.2 Workshop on Geometric Modelling, Airlie, VA, May 1996, Chapman \& Hall, 1997.

[27] Pratt, M., "Provision of an Explicit Constraints Schema in the STEP Standard," in Geometric Modelling: Theory and Practice (W. Strasser, R. Klein \& R. Rau, eds.), Conference proceedings, Blaubeuren, Germany, October 1996; Springer-Verlag 1997.

[28] Pratt, M., "Progress and Problems in Extending the STEP Standard," in Geometric Constraint Solving and Applications (B. Bruederlin and D. Roller, eds.), Conference proceedings, Ilmenau, Germany, September 1997, Springer-Verlag (1998).

[29] Pratt, M., "Extension of the Standard ISO 10303 (STEP) for the Exchange of Parametric and Variational CAD Models," Proceedings of IFIP WG5.2/5.3 Conference PROLAMAT '98, Trento, Italy, September 1998. Available: http://www.mel.nist.gov/msidlibrary/summary/9822.html

[30] Sudarsan, R., Narahari, Y., Lyons, K., Duffey, M., Sriram, R., "Design for Tolerance of Electro-mechanical Assemblies", IEEE International Conference on Robotics and Automation, Leuven, Belgium, May 1998.

Available: http://www.mel.nist.gov/msidlibrary/summary/9802.html

[31] Sudarsan, R., Lyons, K., Narahari, Y., Duffey, M., "Design for Tolerance of Electro-mechanical Assemblies", 3rd National Seminar on Tolerancing and Assembly Modeling, Ann Arbor, MI, October 1997.

IS7: Framework, (p. 24)

[32] Barkmeyer, E., "SIMA Reference Architecture: Part 1, Activity Model", NISTIR 5939, NIST, Gaithersburg, MD, December 1996.

Available: http://www.mel.nist.gov/msidlibrary/summary/9722.html

[33] Bloom, H., Christopher, N., "A Framework for Discrete Parts Manufacturing”, Proceedings of CALS Expo96, Long Beach, CA, October 1996.

Available: http://www.nist.gov/msidlibrary/summary/9661.html

[34] Christopher, N., "NAMT Framework for Discrete Parts Manufacturing: Experience Report", Plug and Play Software for Agile Manufacturing: SPIE Photonics East '96 Symposium, Boston, MA, November 1996.

Available: http://www.nist.gov/msidlibrary/summary/9670.html

[35] Christopher, N., Stewart, S., "NAMT Framework for Discrete Parts Manufacturing: Industrial Review Roundtable '96", NISTIR 5924, NIST, Gaithersburg, MD, November 1996.

Available: http://www.nist.gov/msidlibrary/summary/9668.html

[36] Flater, D., “CORBA: Lessons Learned in the NAMT Framework Demo”, January 1997

Available: http://www.mel.nist.gov/msidstaff/flater/llclean/ 
[37] Flater, D., Wallace, E., "Programmer's Guide to the 1996 Demo Executor", NISTIR 5980, NIST, Gaithersburg, MD, February 1997.

Available: http://www.nist.gov/msidlibrary/summary/9711.html

[38] Flater, D., Wallace, E., Barkmeyer, E., "State Models for Jobs and Controllers", NISTIR 6037, NIST, Gaithersburg, MD, July 1997.

Available: http://www.nist.gov/msidlibrary/summary/9733.html

[39] Flater, D., Barkmeyer, E., Wallace, E., Denno, P., Iuliano M., “CIM Framework Experience Report”, NISTIR 6057, NIST, Gaithersburg, MD, August 1997.

Available: http://www.nist.gov/msidlibrary/summary/9745.html

[40] Flater, D., Barkmeyer, E., Wallace, E., "Four Models of Job Control”, International Journal of Computer Integrated Manufacturing, September 1997.

Available: http://www.nist.gov/msidlibrary/summary/9751.html

[41] Mills, J., Christopher, N., et al., "Adaptive, Responsive Information Systems: A Next Generation Manufacturing Imperative", Next Generation Manufacturing Project Report, Volume II, Agility Forum, January 1997.

[42] Moncarz, H., "Effective Communication Platforms", NISTIR 5974, NIST, Gaithersburg, MD, March 1997.

[43] Wallace, E., Clements, P., Wallnau, K., "Discovering a System Modernization Decision Framework: A Case Study in Migrating to Distributed Object Technology", Proceedings of the International Conference on Software Maintenance, Monterey, CA, November 1996.

Available: http://www.nist.gov/msidlibrary/summary/9614.html

[44] Wallnau, K., Wallace, E., "A Robust Evaluation of the Object Management Architecture: A Focused Case Study in Legacy System Migration”, Proceedings of OOPSLA'96, San Jose, CA, October 1996.

Available: http://www.nist.gov/msidlibrary/summary/9613.html

IS8: Operator Interfaces for Virtual and Distributed Manufacturing, (p. 26)

[45] Falco, J., Kent, E., "Virtual Manufacturing Tools for Collaborative Exploration of Hexapod Machine Capabilities and Applications", Proceedings of 1997 International CIRP Design Seminar, Los Angeles, CA, October 1997.

Available: http://www.isd.cme.nist.gov/documents/falco/

IS9: Process Specification Language, (p. 27)

[46] Gruninger, M., Schlenoff, C., Knutilla, A., Ray, S., "Using Process Requirements as the Basis for the Creation and Evaluation of Process Ontologies for Enterprise Modeling", ACM SIGGROUP Bulletin, Vol. 18, No. 2, August 1997.

[47] Knutilla, A., Schlenoff, C., Ray, S., Tate, A., Polyak S., Cheah, S., Anderson, R., "Process Specification Language: An Analysis of Existing Representations”, NISTIR 6160, NIST, Gaithersburg, MD, May 1998.

Available: http://www.nist.gov/msidlibrary/summary/9807.html

[48] Moncarz, H., et al., "Proceedings of the First Process Information Technology (PIT) Workshop", NISTIR 6206, NIST, Gaithersburg, MD, July, 1998.

[49] Polyak, S., "Process Plan Representation Scenario", Artificial Intelligence Applications Institute (AIAI), Edinburgh, UK, March 1998.

[50] Polyak, S., Aitken, S., "Manufacturing Process Interoperability Scenario", AIAI-PR-86, Artificial Intelligence Applications Institute (AIAI), Edinburgh, UK, June 1998.

[51] Polyak, S., Tate, A., "Analysis of Candidate PSL Process/Plan Representations," AIAI-PR-66, Artificial Intelligence Applications Institute (AIAI), Edinburgh, UK, February 1998. 
[52] Schlenoff, C., Ivester, R., Knutilla, A., “A Robust Ontology for Manufacturing Systems Integration”, Proceedings of the 2nd International Conference on Engineering Design and Automation, Maui, HI, August 1998.

Available: http://www.nist.gov/msidlibrary/summary/9804.html

[53] Schlenoff, C., Knutilla, A., Ray, S., "Requirements for Modeling Manufacturing Process", Proceedings of the Intelligent Systems: A Semiotic Perspective Conference, NIST, Gaithersburg, MD, October 1996.

[54] Schlenoff, C., Knutilla, A., Ray, S., "Requirements for Modeling Manufacturing Process: A New Perspective", Proceedings of the 1997 Computers in Engineering Conference, Sacramento, CA, September 1997.

Available: http://www.nist.gov/msidlibrary/summary/9732.html

[55] Schlenoff, C., Knutilla, A., Ray, S., "Unified Process Specification Language: Requirements for Modeling Process", NISTIR 5910, NIST, Gaithersburg, MD, September 1996.

Available: http://www.nist.gov/msidlibrary/summary/9660.html

[56] Schlenoff, C., Knutilla, A., Ray, S., "Proceedings of the Process Specification Language Roundtable", NISTIR 6081, NIST, Gaithersburg, MD, October 1997.

Available: http://www.nist.gov/msidlibrary/summary/9752.html

IS10: Production and Product Data Management Applications, (p. 29)

[57] Bartolotta, A., McLean, C., Lee, Y.T., Jones, A., "Production Systems Engineering: Requirements Analysis for Discrete-event Simulation", NISTIR 6154, NIST, Gaithersburg, MD, April 1998.

Available: http://www.nist.gov/msidlibrary/summary/9806.html

[58] Ellis, K., Jones A., Lee, Y.T., "Requirements Analysis: Process Plan Specification - Workstation Level", NISTIR 6172, NIST, Gaithersburg, MD, June 1998.

Available: http://www.nist.gov/msidlibrary/summary/9812.html

[59] Iuliano, M., "The Role of Product Data Management in the Manufacturing Engineering Toolkit", NISTIR 6042, NIST, Gaithersburg, MD, August 1997.

Available: http://www.nist.gov/msidlibrary/summary/9736.html

[60] Iuliano, M., Jones, A., Feng, S., “Analysis of AP213 for Usage as a Process Plan Format”, NISTIR 5992, NIST, Gaithersburg, MD, March 1997.

Available: http://www.nist.gov/msidlibrary/summary/9716.html

[61] Jones, A., Iuliano, M., “Controlling Activities in a Virtual Manufacturing Cell”, Proceedings of WSC'96 Conference, San Diego, CA, December 1996.

[62] Jones, A., Iuliano, M., "A Simulation-based Production Testbed", Proceedings of Winter Simulation Conference 1997, Atlanta, GA, December 1997.

Available: http://www.nist.gov/msidlibrary/summary/9743.html

[63] Jones, A., Iuliano, M., “A Virtual Manufacturing Testbed”, Proceedings of SMC '97, Orlando, FL, October 1997.

[64] Jones, A., McLean, C., "Industrial Need: Production Management Standards", NISTIR 6058, NIST, Gaithersburg, MD, September 1997.

Available: http://www.nist.gov/msidlibrary/summary/9748.html

[65] Jones, A., McLean, C., Leong, S., “A Virtual Production Testbed”, Proceedings of WCSS'97, Singapore, September 1997.

[66] Jones, A., Rabelo, L., "Genetic Computing and Job Shop Scheduling”, Proceedings of Semiotics Conference, Gaithersburg, MD, October 1996. 
[67] Kaing, S., "Business Model for Document Classification and Workflow", Ecole Supérieure d'Informatique et Applications de Lorraine, Nancy, France, July 1997.

[68] LeCapitaine, C., Riddick, F., Jones, A., "Production Management Standards: Requirements Analysis for Shop Floor Status", NISTIR 6123, NIST, Gaithersburg, MD, March 1998.

Available: http://www.nist.gov/msidlibrary/summary/9801.html

[69] Lee, Y.T., "Initial Manufacturing Exchange Specification (IMES): Requirement Analysis for the Plant Layout Application", NISTIR 6139, NIST, Gaithersburg, MD, July 1998.

Available: http://www.nist.gov/msidlibrary/summary/9805.html

[70] Ling, Z., "Assembly Modeling and Sequence Planning Based on the Kinematics of Features", Proceedings of the ASME 1996 Design Engineering Technical Conferences, Irvine, CA, 1996.

[71] Ling, Z., McLean, C., Zhou, X., “A Hybrid Assembly Process Planning System”, NISTIR 6070, NIST, Gaithersburg, MD, September 1997.

[72] McLean, C., "Production System Engineering Using Virtual Manufacturing", Proceedings of the 1997 World Manufacturing Congress, Auckland, New Zealand, November 1997.

[73] McLean, C., "Tools and Techniques for Modeling Production Systems", $\underline{\text { Strategic Management of the }}$ Manufacturing Value Chain, Kluwer Academic Publishers, Boston, MA, 1998.

[74] McLean, C., Leong, S., "Industrial Need: Production System Engineering Integration Standards", NISTIR 6019, NIST, Gaithersburg, MD, May 1997.

Available: http://www.nist.gov/msidlibrary/summary/9727.html

[75] Mungwattana, A., Shewchuk, J., Jones, A., "Validation and Simulation of Manufacturing Engineering Data", Proceedings of the 7th International Conference on Flexible Automation and Intelligent Manufacturing, Middlesbrough, U.K., June 1997.

[76] Riddick, F., "Using Simulation as a Proxy for a Real Shop Floor and Data Collection System", Proceedings of the Deneb 1997 Simulation Conference, Detroit, MI, September 1997.

[77] Riddick, F., "Reactive Scheduling System Implementations Using a Simulated Shop Floor", Proceedings of IASTED Applied Modelling and Simulation Conference, Honolulu, Hawaii, August 1998.

Available: http://www.nist.gov/msidlibrary/summary/9816.html

[78] Riddick, F., "Using Simulation as a Proxy for a Real Shop Floor", NISTIR 6173, NIST, Gaithersburg, MD, May 1998.

Available: http://www.nist.gov/msidlibrary/summary/9810.html

[79] Riddick, F., Loreau, A., "Models For Integrating Scheduling And Shop Floor Data Collection System", Proceedings of IASTED MIC'97, Innsbruck, Austria, February 1997.

Available: http://www.nist.gov/msidlibrary/summary/9710.html

[80] SEMATECH CIM Framework v1.5, SEMATECH TT \#93061697H-ENG, June 1997.

[81] Umeda, S., Jones, A., "Simulation in Japan: State-of-the-Art Update", NISTIR 6040, NIST, Gaithersburg, MD, July 1997.

[82] Umeda, A., Jones, A., "Virtual Supply Chain Management: A Re-engineering Approach Using Discrete Event Simulation", Proceedings of the World Conference SCI'97, Caracas, Venezuela, July 1997.

Available: http://www.nist.gov/msidlibrary/summary/9738.html

[83] Umeda, S., Jones, A., "Virtual Supply Chain System: A Testbed Using Discrete Event Simulation", Proceedings of 18th ASEM Conference, Virginia Beach, VA, October 1997.

[84] Umeda, S., Jones, A. "Virtual Supply Chain System: A Testbed System Using Discrete Event Simulation", Proceedings of American Society of Engineering Management Conference, Norfolk, VA, October 1997. 
[85] Umeda, S., Morito, S., "Industrial Practices of Discrete Event Simulation in Japan - A Comprehensive Survey", Proceedings of WCSS '97, Singapore, September 1997.

IS11: Reference Model Architecture, (p. 31)

[86] Albus, J., DeClaris, N., Lacaze, A., Meystel, A., "Neural Network Based Planner/Learner for Control Systems", Proceedings of Intelligent Systems and Semiotics '97 Conference, Gaithersburg, MD, September 1997.

[87] Albus, J., Lacaze, A., Meystel, A., "Multi-resolutional Planning with Minimum Complexity", Proceedings of Intelligent Systems and Semiotic '97 Conference, Gaithersburg, MD, September 1997.

[88] Horst, J., Beichel, I., "A Simple Algorithm for Efficient Piecewise Linear Approximation of Space Curves", IEEE International Conference on Image Processing, Santa Barbara, October 1997.

[89] Horst, J., Messina, E., Kramer, T., Huang, H., "Precise Definition of Software Component Specifications", Proceedings of the 1997 IFAC Computer-Aided Control System Design Conference, Ghent, Belgium, April 1997.

Available: http://isd.cme.nist.gov/documents/horst/SCS.pdf

[90] Huang, H., Proctor, F., "An Open System Intelligent Manufacturing Architecture: the Concept and the Approach", 36th IEEE Conference of Decision and Control, San Diego, CA, December 1997.

[91] Huang, H., Proctor, F., "An Implementation Approach for an Intelligent Manufacturing Architecture", Proceedings of Intelligent Systems and Semiotics '97 Conference, Gaithersburg, MD, September 1997.

[92] Kramer, T., Proctor, F., Rippey, W., Scott, H., "The NIST DMIS Interpreter", NISTIR 6012, NIST, Gaithersburg, MD, April 1997.

Available: http://isd.cme.nist.gov/documents/kramer/DMIS.ps

[93] Meystel, A., Lacaze, A., "Introduction to Integrated Learning/Planning Paradigm”, Proceedings of Intelligent Systems and Semiotics '97 Conference, Gaithersburg, MD, September 1997.

[94] Meystel, A., Lacaze, A., "Unified Learning/Planning Automation: Generating and Using Multigranular Knowledge Hierarchies", Proceedings of Intelligent Systems and Semiotic '97 Conference, Gaithersburg, MD, September 1997.

[95] Senehi, M., Kramer T., “A Framework for Control Architectures”, International Journal of Computer Integrated Manufacturing, Volume 11, Number 4, July-August 1998.

Available: http://www.isd.cme.nist.gov/documents/kramer/

IS12: STEP Conformance and Interoperability Testing, (p. 33)

[96] "Abstract Test Suite Development Guidelines", SC4 Standing Document ISO/TC 184/SC4 N536. Available: http://www.nist.gov/sc4/ndocs/archive/1997/

[97] Barnard, A., McKee, L., "Industrial Automation Systems and Integration. Product Data Representation and Exchange. Part 203: Application Protocol: Configuration Controlled 3D Designs of Mechanical Parts and Assemblies. TECHNICAL CORRIGENDUM 2”, ISO TC 184/SC4 N742 1998-06-22, July 1998.

[98] Denno, P., "Overview of NIST Expresso”, NIST, Gaithersburg, MD, December, 1997.

Available: http://www.mel.nist.gov/msidstaff/denno/nist-expresso.html

[99] Frechette, Simon, "Conformance and Interoperability Testing of STEP", Proceedings of SIMA Tutorial Conference, NIST, Gaithersburg, MD, September 1998.

[100] Frechette, S., "STEP Implementation: Solid Model Exchange Results in the AutoSTEP Pilot Project", 6th Annual National Agility Conference, San Diego, CA, March 1997.

[101] Frechette, S., Montano, A., "Procedures for Product Data Exchange Using STEP in the AutoSTEP Project", Automotive Industry Action Group, Southfield, MI, April 1997. 
IS13: STEP for the Process Plant Industries, (p. 35)

[102] Kline, S., Palmer, M., Appel, N., Gilbert, M., "Group 1 for the Process Engineering Data STEP Application Protocol”, NISTIR 5909, NIST, Gaithersburg, MD, October 1996.

Available: http://flame.cfr.nist.gov/bfrlpubs/build96/art144.html

[103] Kline, S., Palmer, M., Appel, N., Gilbert, M., "Plant Spatial Configuration STEP Application Protocol”, NISTIR 6005, NIST, Gaithersburg, MD, March 1997.

Available: http://flame.cfr.nist.gov/bfrlpubs/build96/art118.html

[104] Kline, S., Palmer, M., Fielding, J., Gilbert, M., Teague, T., Witherell, D., "Process Engineering Data STEP Application Protocol, Version 1.0", NISTIR 6200, NIST, Gaithersburg, MD, June 1998.

[105] Palmer, M., Halford, J., "The PIEBASE Roadmap to Achieve the Industry Vision for Information Exchange and Sharing", Gaithersburg, MD, October 1997.

Available: http://flame.cfr.nist.gov/bfrlpubs/build98/art007.html

IS14: Virtual Environments and Visualization for Manufacturing, (p. 36)

[106] Rajan, V., et al., "Simulation of Manual Assembly Tasks", Proceedings 10 International IFIP WG5.2, WG5.3 Conference (PROLAMAT 98), Trento, Italy, September 1998.

[107] Ressler, S., Wang, Q., Bodarky, S., Sheppard, C., Seidman, G., "Using VRML to Access Manufacturing Data", Proceedings of VRML97 Second Symposium on the Virtual Reality Modeling Language, Monterey CA, February 1997.

Available: http://www.nist.gov/itl/div894/ovrt/vrm197/html/vim.htm

[108] Ressler, S., Wang, Q., "Integrating Factory Floor and Human Simulations in a Portable Web-Based Environment", Proceedings of Human Factors and Ergonomic Society European Chapter, Bochum, Germany, November 1997.

[109] Ressler, S., Wang, Q., "Making VRML Accessible for People with Disabilities”, Proceedings of ASSETS 98, Marina Del Rey, CA, February 1998.

[110] Wang, Q., “Translating IGRIP Workcells into VRML2”, NISTIR 6076, NIST, Gaithersburg, MD, September 1997.

IA4: Green's Function Library for Advanced Materials Applications with Web Access, (p. 41)

[111] Lu, S., Weng, G., Pan, L., Rizzo, F., "Discretized Green's Function Libraries for Elastodynamics and Acoustics", Proceedings of the International Conference on Computing and Engineering Science, Atlanta, GA, October 1998.

[112] Pan, L., Adams, D., Rizzo, F., "BEM Analysis for Composite Materials and a Library of Green's Functions", Computers and Structures, Vol. 66, No. 5, March 1998

.IA5: Integration of NIST Standard Reference Data into Information Networks, (p. 41)

[113] Dalton, G., et al., "NIST Atomic Spectra Database", Poster Papers, International Conference on Atomic and Molecular Data and Their Applications, NIST Special Publication 926, NIST, Gaithersburg, MD, August 1998.

[114] Dragoset, R., Mohr, P., Olsen, K., Saloman, E., Wiersma, G., and Zucker, D., "NIST Atomic and Molecular Databases on the World Wide Web", Poster Papers, International Conference on Atomic and Molecular Data and Their Applications, NIST Special Publication 926, NIST, Gaithersburg, MD, August 1998.

IA6: NIST Ceramics WebBook, (p. 42)

[115] Begley, E., Munro, R., "Web SCD Structural Ceramics Database".

Available: http://www.ceramics.nist.gov/srd/scd/scdquery.htm 
FY97-98 Project Publications

IA7: Online Access to NIST Chemical Reference Data, (p. 42)

[116] Mallard, W., Lindstrom, P., "NIST Chemistry Web Book".

Available: http://webbook.nist.gov/

IA8: Standards for Exchange of Instrument Data and NIST Chemical Reference Data, (p. 43)

[117] Kramer, G., Grandsard, P., "An Inexpensive Video Signal Multiplexer for Multicamera Machine Vision in Automated Analytical Laboratory Systems,” Laboratory Robotics and Automation, Vol. 10, 1998.

[118] Piotrowski, C., Richter, T., Schaefer, R., Kramer, G., "The System Capability Dataset for Laboratory Automation System Integration," Journal of the Association for Laboratory Automation, in press.

[119] Salit, M., Griesmeyer, J., "System-Ready Behaviors for Integration”, Laboratory Robotics and Automation, (9), 1997.

[120] Stab, T., Kramer, G., "The Device Capability Dataset: A Descriptive Approach to Laboratory Automation System Integration Standards," Journal of the Association for Laboratory Automation, in press. 


\section{Appendix D: Program Products Newly Available in FY97-98}

\section{Software/Services}

\section{EXPRESS Web Server}

The EXPRESS Web Server is a World Wide Web interface for standards developers creating specifications for STEP, the STandard for the Exchange of Product model data (officially ISO 10303). The Server enables users to run applications needed to build and populate EXPRESS specifications using a Web browser and without having to install and configure the applications locally. The Server also allows users to share EXPRESS specifications and data sets with one another, providing standards development teams with an infrastructure for collaboration.

Available: http://pitch.nist.gov/cgi-bin/sauder/express-server/server.cgi

\section{Manufacturer's CORBA Interface Testing Toolkit (MCITT)}

The Common Object Request Broker Architecture (CORBA) supports the construction of distributed systems containing many components. These components can interact in complex ways, not necessarily conforming to a strict client-server model. This generality is necessary to enable many real-world systems to be built on a distributed architecture. However, it is also the reason why testing these systems is so difficult. Because each component can have complex dependencies on any number of other components, it is often impossible to test them in isolation. MCITT mitigates this problem by minimizing the amount of effort needed to produce simple emulations -- test servers -- that can be used to replace actual servers in a testing scenario. Once the behaviors important for a given scenario are specified, MCITT will automatically generate CORBA boilerplate code, memory management, and stubs for unused operations.

Available: http://www.mel.nist.gov/msidstaff/flater/mcitt/

NIST Expresso version 1.5.1 (updated Beta-test version)

NIST Expresso is a language environment for the ISO EXPRESS language (ISO10303-11) providing tools to aid in the development and validation of EXPRESS information models and representative data sets. NIST Expresso is available as an executable that runs under Microsoft Windows 95 and NT operating systems. The downloadable PC executable allows the user to specify and incrementally modify his own EXPRESS information model for analysis and validation. It may also be used to build representative data sets for the subject schema.

Available: ftp://ftp.nist.gov/pub/mel/denno/beta/expresso1-5-1.exe

\section{$\underline{\text { STEP Conformance Testing System }}$}

The STEP conformance testing systems, or NITS (NIST-ITI Test System) is a WWW-based resource designed to support the testing needs of software application developers who are implementing STEP standards. Developers, and users as well, can access NITS and interactively execute tests on their implementations in order to ascertain the degree to which these implementations conform to a specific standard. Currently, NITS specifically provides for testing of implementations of the STEP standard for configuration controlled design (ISO SC4 203). NITS provides reference test case data and integrates independent test tools such as generators, analyzers, and recorders into a repeatable and traceable process. NITS also provides users a common interface for administrative support in collecting, organizing, and reviewing test results.

Available: http://frigg.erim.org:8080/nits 


\section{Program Products Newly Available in FY97-98}

\section{Standard Reference Databases ${ }^{2}$}

XCOM: Photon Cross Sections Database, Berger, M., Hubbell, J.

A web database that can be used to calculate photon cross sections for scattering, photoelectric absorption and pair production, as well as total attenuation coefficients, for any element, compound or mixture $(\mathrm{Z} \leq 100)$, at energies from $1 \mathrm{keV}$ to $100 \mathrm{GeV}$.

Available: http://physics.nist.gov/PhysRefData/Xcom/Text/XCOM.html

$\underline{X-R a y}$ Form Factor, Attenuation and Scattering Tabulation, Chantler, C.

The primary interactions of $\mathrm{x}$-rays with isolated atoms from $\mathrm{Z}=1$ (hydrogen) to $\mathrm{Z}=92$ (uranium) are described and computed within a self-consistent Dirac-Hartree-Fock framework. This has general application across the range of energy from $1 \mathrm{eV}-10 \mathrm{eV}$ to $400 \mathrm{keV}-1000 \mathrm{keV}$, with limitations as the low- and high-energy extremes are approached. Tabulations are provided for the $\mathrm{f}_{1}$ and $\mathrm{f}_{2}$ components of the form factors, together with the photoelectric attenuation coefficient for the atom, $\mu$, and the value for the $\mathrm{K}$-shell, $\mu_{\mathrm{K}}$, as functions of energy and wavelength. Also provided are estimated correction factors as described in the text, conversion factors, and a simple estimate for the sum of the scattering contributions (from an isolated atom).

Available: http://physics.nist.gov/PhysRefData/FFast/Text/cover.html

Fundamental Physical Constants Database, Cohen, E., Taylor, B.

This site addresses three topics: fundamental physical constants, the International System of Units (SI), which is the modern metric system, and expressing the uncertainty of measurement results. Both essential information and background information are given for each topic.

Available: http://physics.nist.gov/cuu/Constants/index.html

Electron-Impact Ionization Cross Section Database, Kim, Y., Rudd, M.

This is a database primarily of total ionization cross sections of molecules by electron impact. The database also includes cross sections for a small number of atoms and energy distributions of ejected electrons for $\mathrm{H}, \mathrm{He}$, and $\mathrm{H}_{2}$. The cross sections were calculated using the Binary-Encounter-Bethe (BEB) model, which combines the Mott cross section with the high-incident energy behavior of the Bethe cross section. Selected experimental data are included. Available: http://physics.nist.gov/PhysRefData/Ionization/Xsection.html

NIST Chemistry WebBook, Mallard, W., Linstrom, P.

The WebBook provided access to the full array of data compiled and distributed by NIST under the Standard Reference Data Program, including thermochemical data for over 5000 organic and small inorganic compounds, reaction thermochemistry data for over 8000 reactions, infrared spectra for over 5000 compounds, and thermophysical property data for 16 fluids.

Available: http://webbook.nist.gov/

Ground Levels and Ionization Energies for the Neutral Atoms, Martin, W., Musgrove, A.

The ionization energies in the table are based on a recent survey of the literature. A reference to one or another data compilation is given for a number of elements; the cited compilation gives the reference(s) for the original ionizationenergy data. The uncertainties are mainly in the range from less than one to several units in the last decimal place, but a few of the values may be in error by 20 or more units in the final place; i.e., the error of some of the two place values could be greater than $0.2 \mathrm{eV}$. Estimated uncertainties of the ionization energies are usually given in the references. Although no more than four decimal places are given, the accuracies of some of the better known values would, in eV units, be limited only by the uncertainty in the conversion factor, $1.23984244(37) \infty 10^{-4} \mathrm{eV} / \mathrm{cm}^{-1}$. Available: http://physics.nist.gov/PhysRefData/IonEnergy/ionEnergy.html

2. More information on Standard Reference Data products can be found at http://www.nist.gov/srd/. 


\section{References}

Radionuclide Half-Life Measurements Made at NIST, Unterweger, M., Hoppes, D., Schima, F.

The half lives of many radionuclides have been measured in the Radioactivity Group of NIST over the last three decades. The results of these measurements for many long-lived radionuclides, such as ${ }^{60} \mathrm{Co},{ }^{137} \mathrm{Cs},{ }^{85} \mathrm{Kr},{ }^{22} \mathrm{Na}$, ${ }^{133} \mathrm{Ba},{ }^{207} \mathrm{Bi},{ }^{152} \mathrm{Eu},{ }^{154} \mathrm{Eu},{ }^{155} \mathrm{Eu}$, and ${ }^{125} \mathrm{Sb}$ have been recently revised. The results for the half lives of the many radionuclides measured over the last three decades are tabulated. The table is the revised listing of the half lives determined at NIST since 1967 and supersedes the table presented in NBS Special Publication 626 [D.D. Hoppes and F.J. Schima, ed. (1982), p. 85]. The half lives of radionuclides not previously reported are noted as well as those which have been significantly revised. The revised values for the half lives of various "short-lived" radionuclides arise from improved impurity analysis, incorporation of additional data from new sources, and reevaluation of old data.

Available: http://physics.nist.gov/PhysRefData/Halflife/halflife.html 